\title{
REGULATING RACIST SPEECH ON CAMPUS: A MODEST PROPOSAL? $\dagger$
}

\author{
NADINE STROSSEN*
}

TABLE OF CONTENTS

Introduction

I. Some Limited Forms of Campus Hate Speech May Be Regulable Under Current Constitutional Doctrine..........

A. General Constitutional Principles Applicable to Regulating Campus Hate Speech ..................

B. Particular Speech-Limiting Doctrines Potentially Applicable to Campus Hate Speech ................ 507

1. Fighting Words ......................... 508

2. Intentional Infliction of Emotional Distress ........ 514

$\dagger$ The title is drawn from Jonathan Swift's essay $A$ Modest Proposal for preventing the Children of poor People from being a Burthen to their Parents or the Country, and for Making them Beneficial to the Public (Dublin 1729), in Jonathan SwiFt 492 (A. Ross \& D. Woolley eds. 1984). This Article not only responds to the specific points made in Lawrence, If He Hollers Let Him Go: Regulating Racist Speech on Campus, 1990 DUKE L.J. 431 [hereinafter Lawrence], but also addresses the general issues raised by the many recent proposals to regulate racist and other forms of hate speech on campus. Professor Strossen's Article, as well as Professor Lawrence's, are expanded versions of oral presentations that they made at the Biennial Conference of the American Civil Liberties Union (ACLU) in Madison, Wisconsin on June 16, 1989 (available from author). After discussion of these presentations, the Conference adopted the following resolution:

The ACLU should undertake educational activities to counter incidents of racist, sexist, anti-semitic and homophobic behavior (including speech) on school campuses and should encourage school administrators to speak out vigorously against such incidents. At the same time, the ACLU should undertake educational activities to counter efforts to limit or punish speech on university campuses.

The ACLU has taken action to implement both prongs of this resolution. See infra note 17 and text accompanying notes 344-55.

* Professor of Law, New York Law School. A.B., 1972, Harvard-Radcliffe College; J.D., 1975, Harvard Law School. Professor Strossen is a General Counsel to the ACLU, and serves on its Executive Committee and National Board of Directors. She thanks Charles Baron, Jcan Bond, Ava Chamberlain, Elsa Cole, Donald Downs, Eunice Edgar, Stephen France, Ira Glasser, David Gold. berger, Thomas Grey, Gerald Gunther, Nat Hentoff, Mary Heston, Martin Margulies, Mari Matsuda, Michael Meyers, Gretchen Miller, Colleen O'Connor, Taggarty Patrick, john powell, John Roberts, Alan M. Schwartz, Judge Harvey Schwartz, Robert Sedler, Norman Siegel, Peter Siegel, William Van Alstyne, and Jane Whicher for information and insights they shared regarding the subject of this Article. For comments on earlier versions of the Article, she thanks Ralph Brown, Edward Chen, Norman Dorsen, Bernie Dushman, Stanley Engelstein, Eric Goldstein, Franklyn Haiman, Morton Halperin, Alon Harel, Leanne Katz, Martin Margulies, Maimon Schwarzschild, and Samuel Walker. For their research assistance, she cxpresses special thanks to Jennifer Colyer and Marie Newman, who provided help throughout this project. For additional research assistance, she thanks Marie Costello, Jayni Edelstein, Ramyar Moghadassi, and Julia Swanson. 
3. Group Defamation

C. Even a Narrow Regulation Could Have a Negative

Symbolic Impact on Constitutional Values

II. Professor Lawrence's Conception of Regulable Racist

Speech Endangers Free Speech Principles

A. The Proposed Regulations Would Not Pass

Constitutional Muster

1. The Regulations Exceed the Bounds of the Fighting Words Doctrine ............................ 524

2. The Regulations Will Chill Protected Speech ...... 526

B. The Proposed Regulations Would Endanger

Fundamental Free Speech Principles ....

1. Protection of Speech Advocating Regulable Conduct.

2. Proscription on Content-Based Speech Regulations... 533

a. The indivisibility of free speech. ............. 533

b. The slippery slope dangers of banning racist speech.

c. The content-neutrality principle reflects sensitivity to hate speech's hurtful power.

III. Professor Lawrence's Rationales for Regulating Racist. Speech Would Justify Sweeping Prohibitions, Contrary to Free Speech Principles

A. Brown and Other Cases Invalidating Governmental. Racist Conduct Do Not Justify Regulating NonGovernmental Racist Speech ..................... 541

1. The Speech/Conduct Distinction .............. 542

2. The Private Action/State Action Distinction ....... 544

B. The Non-Intellectual Content of Some Racist Speech Does Not Justify Its Prohibition

IV. Prohibiting Racist Speech Would Not Effectively Counter, and Could Even Aggravate, the Underlying Problen of Racisin

A. Civil Libertarians Should Continue to Make Combating Racism a Priority

B. Punishing Racist Speech Would Not Effectively Counter Racism .................................. 554

C. Banning Racist Speech Could Aggravate Racism ...... 555

V. Means Consistent with the First Amendinent Can Promote Racial Equality More Effectively Than Can Censorship..... 562 Conclusion ....................................... 569 
Freedom of speech is indivisible; unless we protect it for all, we will have it for none. ${ }^{1}$

-Harry Kalven, Jr.

If there be minority groups who hail this holding [rejecting a first amendment challenge to a group libel statute] as their victory, they might consider the possible relcvancy of this ancient remark: "Another such victory and I am undone."2

-Hugo Black, Jr.

The civil rights movement would have been vastly different without the shield and spear of the First Amendment. The Bill of Rights . . . is of particular importance to those who have been the victims of oppression. ${ }^{3}$

-Benjamin L. Hooks

It is technically impossible to write an anti-speech code that cannot be twisted against speech nobody means to bar. It has been tried and tried and tried. ${ }^{4}$

-Eleanor Holmes Norton

The basic problem with all these regimes to protect various people is that the protection incapacitates. ... To think that I [as a black man] will . . . be told that white folks have the moral character to shrug off insults, and I do not .... That is the most insidious, the most insulting, the most racist statement of all! ${ }^{5}$

-Alan Keyes

Whom will we trust to censor communications and decide which ones are "too offensive" or "too inflaminatory" or too devoid of intellectual content? . . . As a former president of the University of Califoruia once said: "The University is not engaged in unaking ideas safe for students. It is engaged in making students safe for ideas."

-Derek Bok

[R]estrictive codes ... may be expedient, even grounded in conviction, but the university cannot subinit the two cherished ideals of freedom and equality to the legal system and expect both to be returned intact.? - Carnegic Foundation for the Advancement of Teaching

1. Kalven, Upon Rereading Mr. Justice Black on the First Amendment, 14 UCLA L. REV. 428, 432 (1967).

2. Beauharnais v. Illinois, 343 U.S. 250, 275 (1952) (Black, J., dissenting).

3. Statement by Benjamin Hooks, quoted in Philip Morris Companies Inc., Press Release (May 7, 1990).

4. Gottlieb, Banning bigoted speech: Stanford weighs rules, San Jose (Cal.) Mercury-News, Jan. 7,1990 , at 3 , col. 1 .

5. Stanford News, Press Release (Mar. 19, 1990) (quoting Alan Keyes, a former assistant secretary of state and now president of Citizens Against Government Waste, criticizing Stanford hate speech regulation).

6. Bok, Reflections on Free Speech: An Open Letter to the Harvard Community. Educ. REC, Winter 1985, at 4, 6 .

7. Carnegie Foundation for the Advancement of Teaching, A Speclal Report: Campus Life, In Search of Community 20 (1990) [hereinafter Carnegie Found. Special. REPORT]. 
In the political climate that surrounds [the race] issue[ ] on campus, principle often yields to expediency and clarity turns into ambiguity, and this is no less true for some of our finest scholars. ${ }^{8}$

-Joseph Grano

When language wounds, the natural and immediate impulse is to take steps to shut up those who utter the wounding words. When, as here, that impulse is likely to be felt by those who are normally the first amendment's staunchest defenders, free expression faces its greatest threat. At such times, it is important for those committed to principles of free expression to remind each other of what they have always known regarding the long term costs of short term victories bought through compromising first amendment principles. 9

- Civil Liberties Union of Massachusetts

As a former student activist, and as a current black militant, [I] believe[ ] that free speech is the minority's strongest weapon. . . . [P] aternalism [and] censorship offer the college student a tranquilizer as the antidote to campus and societal racism. What we need is an alarm clock. . . . What we need is free speech ... and more free speech!10

-Michael Meyers

\section{INTRODUCTION}

Professor Lawrence has made a provocative contribution to the perennial debate concerning the extent to which courts and civil libertarians ${ }^{11}$ should continue to construe the Constitution as protecting some $1,19-20$

8. Grano, Free Speech v. the University of Michigan, ACADEMIC Questions, Spring 1990, at

9. Civil Liberties Union of Massachusetts, Policy Concerning Racist and Other Group-Based Harassing Speech Acts on Academic Campuses (adopted May 14, 1990) (principally drafted by Charles H. Baron, Professor of Law, Boston College Law School) (available from author).

10. M.'Meyers, Banning Racist and Other Kinds of "Hate" Speech on the College Campus (outline for a debate with john a. powell at Hofstra University, Hempstead, Long Island, January 25, 1990) (available from author). Michael Meyers is a member of the ACLU's National Board of Directors and its Affirmative Action Officer; john a. powell is the ACLU's National Legal Director.

11. There is no single "civil libertarian" or ACLU position on many of the issues discussed in this Article. For example, Professors Lawrence and Strossen are both avowed civil libertarians and ACLU supporters, see Lawrence, at $434 \mathrm{n} .20,473$, although they disagree on certain civil liberties issues.

On October 13, 1990, the ACLU's National Board of Directors adopted a policy opposing campus disciplinary codes against hate speech. For the text of this policy, which was adopted without dissent, see infra Appendix.

In addition to the national organization, the ACLU includes 51 state-wide or regional "affiliates," which may all adopt their own policies. Although an affiliate's policies must be "in accordancc" with those of the national organization, this requirement is designed "to obtain general unity, rather than absolute uniformity." See Policy Guide of the American Civil Liberties Union, at Policy No. 501 (rev. ed. 1990) [hereinafter ACLU Policy Guide]. Accordingly, some ACLU affiliates may adopt policies concerning the regulation of campus hate speeeh that are to some extent divergent from each other, and from the national ACLU policy. The ACLU California affiliates have adopted a policy that does not oppose the regulation of a limited class of campus hate speeeh, see Policy of 
forms of racist expression. ${ }^{12}$ This recurring issue resurfaced most recently in connection with the increase of racial incidents at colleges and universities around the country. ${ }^{13}$ In response, many of these institutions have adopted, or are considering, ${ }^{14}$ regulations that curb "hate speech"-i.e., speech that expresses hatred or bias toward members of racial, religious, or other groups.

Civil libertarians are committed to the eradication of racial discrimination and the promotion of free speech throughout society. ${ }^{15}$ Civil libertarians have worked especially hard to combat both discrimination and free speech restrictions in educational institutions. ${ }^{16}$ Educational institutions should be bastions of equal opportunity and unrestricted exchange. Therefore, we find the upsurge of both campus racism and regulation of

ACLU California Affiliates Concerning Racist and Other Group-Based Harassment on College Campuses (adopted by ACLU of Northern California, Mar. 8, 1990; ACLU of Southern California, Mar. 21, 1990; and ACLU of San Diego and Imperial Counties, May 24, 1990) (available from author). In contrast, for example, the Civil Liberties Union of Massachusetts has adopted a policy that opposes any content-based restrictions on campus speech. See supra note 9.

To reflect the fact that civil libertarians may differ about the specific issues discussed in this Article, the term "traditional civil libertarian" is used only to describe the general view that much hate speech is entitled to flrst amendment protection. All other, more specific views expressed in this Article reflect the author's opinions. She does not purport to speak either for the national ACLU or for civil libertarians generally.

12. Consistent with Professor Lawrence's approach, see Lawrence, at 436 n.27, this Article focuses on racist speech, although the analysis generally applies to other forms of hate speech as well, such as sexist and homophobic speech, and speech vilifying religious or ethnic groups.

13. See Leslie, Lessons from Bigotry 101, NEWSWEEK, Sept. 25, 1989, at 48 (documents ineidents at 250 colleges and universities since Fall 1986). See also Civil Rights Division of ANT1Defamation league of B'Nal B'rith, Policy Background Report-Campus AmTi-Bias CODES: A NEW FORM OF CENSORSHIP? 1 (1989) (in 1988 there were more reported incidents of anti-Semitic harassment on United States campuses than in any prior year). For a listing of some specific recent incidents of campus racism, see Matsuda, Public Response to Racist Speech: Considering the Victim's Story, 87 MicH. L. REv. 2320, 2333 n.71 (1989).

For some possible explanations for this wave of campus racism, see Steele, The Recoloring of Campus Life, HARPER's, Feb. 1989, at 47.

14. See Carnegie Found. Spec1al Report, supra note 7 , at $19(60 \%$ of the chief student affairs officers surveyed in 1989 reported that their campuses had written polieies on bigotry, racial harassment or intimidation, and another $11 \%$ said they are working on such policies).

15. See generally ACLU Policy Guide, supra note 11, at Policy Nos. 301-31 (ACLU policies advocating equality for racial and other historically disempowered groups). For a summary of the ACLU's efforts to implement these policies, see infra notes 16 \& 334-55 and aceompanying text.

16. It has long been an ACLU priority to combat raeial discrimination in education. For example, during the 1920s and 1930s, the ACLU assisted with the NAACP's formulation of a nationwide legal campaign against segregated edueation. See S. WALKER, IN DEFENSE Of AMERICAN L1BERTIES: A H1STORY OF THE ACLU 88-90 (1990). The Southern California ACLU successfully challenged school segregation as early as 1946. See id. at 239. The ACLU's recent efforts in this category include its representation of the plaintiffs in Brown v. Board of Educ., 892 F.2d 851 (10th Cir. 1989) (Brown III), which challenged the de facto segregation of Topeka, Kansas public schools. See also Memorandum from john a. powell to Ira Glasser and the Executive Committee, March 10, 1990, at 3-4 [hereinafter powell, Memoranduml (listing cases in which ACLU National Legal Department currently is challenging racial discrimination in education) (available from author). 
campus speech particularly disturbing, and we have undertaken efforts to counter both. ${ }^{17}$

Because civil libertarians have learned that free speech is an indispensable instrument for the promotion of other rights and freedomsincluding racial equality-we fear that the movement to regulate campus expression will undermine equality, as well as free speech. Combating racial discrimination and protecting free speech should be viewed as mutually reinforcing, rather than antagonistic, goals. ${ }^{18}$ A diminution in society's commitment to racial equality is neither a necessary nor an appropriate price for protecting free speech. Those who frame the debate in terms of this false dichotomy simply drive artificial wedges between would-be allies in what should be a common effort to promote civil rights and civil liberties. ${ }^{19}$

Professor Lawrence urges civil libertarians to "abandon[ ] . . . overstated rhetorical and legal attacks on individuals who conscientiously seek to frame a public response to racism while preserving our first amendment liberties." 20 I join in this invitation, and I extend a corresponding one: Those individuals who espouse "new perspectives" on the first amendment in an effort to justify hate speech regulations should avoid overstated attacks on those who conscientiously seek to preserve our first amendment liberties while responding to racism.

In important respects, Professor Lawrence inaccurately describes, and unfairly criticizes, both traditional civil libertarians in general and

17. For example, the ACLU represented the plaintiff in Doe v. University of Mich., $721 \mathrm{~F}$. Supp. 852 (E.D. Mich. 1989), which successfully challenged the University of Michigan's anti-hatespeech policy as violating the first amendment. The ACLU also has initiated a lawsuit challenging the University of Wisconsin's hate speech regulation. See Gribble, Student Coalition Sues UW Over Racial Harassment Rule, Milwaukee J., March 30, 1990, at 8B, col. 1. Prior to the adoption of both rules, the ACLU sought to persuade the universities to formulate narrower restrictions. See infra note 353. Compare Lawrence, at 477,478 \& n.162 ("Traditional civil liberties lawyers typically have elected to stand by while universities" adopt "poorly drafted and obviously overbroad regulations.").

See also infra note 177 (discussion of Wu v. University of Conn., Civ. H-89-649 PCD (D. Conn. Jan. 25, 1990). The plaintiff, represented by the Connecticut ACLU affiliate, settled her lawsuit challenging the University of Connecticut's hate speech rule pursuant to an agreement about the wording of an alternative rule.

18. At times, Lawrence recognizes that these goals are in fact mutually reinforcing, see Lawrence, at $435,436 \& \mathrm{n} .27,453 \mathrm{n} .92,455,480 \mathrm{n} .167$, but at other times, he seems to view them as incompatible, see id. at $434,446-47,457-58,466-67,471,473-74$. This is a major unresolved tension in his article.

19. See Gale \& Strossen, The Real ACLU, 2 YALE J.L. \& Feminism 161, 171-84 (1990); see also infra text accompanying notes 422-35 (discussing interdependence of civil rights and civil liberties). Some themes in the present Article were previously explored in the Gale \& Strossen essay. Professor Strossen thanks Professor Gale for her permission to draw upon this earlier piece in the present one.

20. See Lawrence, at 481. 
the American Civil Liberties Union (ACLU) in particular. His argument depends on a "straw civil libertarian" who can be easily knocked down, but who does not correspond to the flesh and blood reality.21 For example, contrary to Professor Lawrence's assumption, traditional civil libertarians do not categorically reject every effort to regulate racist speech. The ACLU never has argued that harassing, intimidating, or assaultive conduct should be immunized simply because it is in part based on words.22 Accordingly, traditional civil libertarians should agree with Professor Lawrence that some examples of racially harassing speech should be subject to regulation consistent with first amendment principles-for example, the group of white male students pursuing a black female student across campus shouting, "I've never tried a nigger."23

Of course, traditional civil libertarians have urged that any restrictions on expressive activity must be drawn narrowly, and carefully applied, to avoid chilling protected speech. But, to a substantial extent,

21. In Professor Lawrence's composite view, "traditional" civil libertarians display the following "typical" propensities. First, they argue that all speech should be absolutely protected, see Lawrence, at $436,438,449,457,461,473-74,476-77$, at least if it "stops short of physical violence," $i d$. at 449. But see infra text accompanying notes 56-77. Second, they rccognize that no face-to-face insults or fighting words are protected frec speech, unless they are raeial in nature, see Lawrence, at 436-37, 476. But see infra text accompanying notes 56-83. Third, they do not acknowledge that racist speech inflicts real harm, see Lawrence, at $448,457,458,478$. But see infra text accompanying notes 275-86. Fourth, they are more committed to the values reflected in the Constitution's free speech clause than to those reflected in its equal protection clause, see Lawrencc, at 448, 461, 477-78. But see infra text accompanying notes 334-57. Fifth, they do not support, and indeed "often" oppose, "group expressions of condemnation" of racist speech, see Lawrencc, at 477. But see infra text accompanying notes 397-402. Sixth, they "typically ... elect [ ] to stand by" while universities draft constitutionally vulnerable hate spech regulations, see Lawrence, at 477 . They "wait [to] attack [such] poorly drafted and obviously overbroad regulations." Id. at 478 n.162. But see infra text accompanying note 353 .

The foregoing stereotypes are presented through unsupported assertions and are belied by the facts recited throughout this Article. Professor Lawrence also makes incorrect and misleading statements specifically about the ACLU and its members. See Lawrence, at 473,478 \& nn.163.64. But see infra text accompanying notes 333-57.

Professor Lawrence qualifies his depiction of the "traditional" civil libertarian or ACLU member in one important respect: He repeatedly suggests that civil libertarians and ACLU members who are members of minority groups (or perhaps women) differ from others in their positions on free speech and equal protection issues. See Lawrence, at 466 (distinguishing "[m]ost blacks" from "many white civil libertarians"); see also id. at 458-59, 461 \& n.113, 473-74, 477-78 \& nn.163-64.

Such racial stereotyping is both factually inaccurate and antithetical to equality principles. The inaceuracy is illustrated by the fact that two ACLU officials, both black, recently engaged in a public debate against each other in which one opposed all campus hate speech regulations. See M. Meyers, supra note 10. Both of these officials agree that the effort to shape appropriately narrow hate speech restrictions entails an undesirable diversion of resources from the essential task of shaping underlying attitudes. Interviews with Michael Meyers and john a. powell, in New York City (August 18, 1990). See also supra text accompanying notes 3-5 \& 10 (quoting black leaders criticizing hate speech regulations).

22. See infra text accompanying notes 53-77 and Appendix.

23. Lawrence, at 448 (quoting $A$ Step Towárd Civility, Time, May 1, 1989, at 43). 
Professor Lawrence appears to endorse a similarly cautious approach. He stresses that he supports only limited regulations and invokes the recently adopted Stanford University code as a model. ${ }^{24}$

Insofar as Professor Lawrence advocates relatively narrow rules that apply traditionally accepted limitations on expressive conduct to the campus setting, his position should not be alarming (although it is debatable). In portions of his article, Professor Lawrence seems to agree with traditional civil libertarians that only a small subset of the racist rhetoric that abounds in our society should be regulated. ${ }^{25}$ Although we may disagree about the contours of such concepts as "captive audience," "fighting words," or "intentional infliction of emotional distress" in the context of racist speech on campus, ${ }^{26}$ these differences should not obscure strong coinmon goals. Surely our twin aims of civil rights and civil liberties would be advanced more effectively by fighting together against the coinmon enemy of racism than by fighting against each other over which narrow subset of one symptom of racism-namely, verbal and symbolic expressions-should be regulated.

What is disquieting about Professor Lawrence's article is not the relatively limited Stanford code he defends, but rather his simultaneous defense of additional, substantially more sweeping, speech prohibitions. ${ }^{27}$

24. See Lawrence, at 450 \& n.82, 481 . Stanford University recently adopted a rule defining some expression as prohibited "harassment by vilification." Stanford University, Fundamental Standard Interpretation: Free Expression and Discriminatory Harassment (June 1990) [hereinafter Stanford Code and Comments]. The rule, which was principally drafted by Professor Thomas Grey, is quoted infra text accompanying note 197.

At various points in his article, Professor Lawrence endorses regulations of broader scope, see infra note 27. However, he stresses his proposed variation of the Stanford code, which would apply to "all common areas" and would "not ... protect[ ] persons ... vilified on the basis of their membership in dominant majority groups." Lawrence, at $450 \mathrm{n} .82$. Therefore, throughout the remainder of this Article, references to the regulation endorsed by Professor Lawrence refer to this formulation, unless expressly indicated otherwise.

25. See Lawrence, at $434-36,450$ \& n.82, 472-73, 474 n.155, 481.

26. Civil libertarians have a range of opinions as to when, if ever, these concepts may legitimately be employed to restrict speech. See infra text accompanying notes $69-87$ \& 116-58. For relevant ACLU policies, see infra note 77. The only doctrinal concept advanced by Professor Lawrence as a justification for regulating campus hate speech that the ACLU expressly and categorically rejects is group defamation. See ACLU Policy Guide, supra note 11, at Policy No. 6(c).

27. See, e.g., Lawrence, at 450 \& n.82 (supports variation on Stanford code which was broader than the one adopted in that it would apply to all common areas); id. at 437, 456-57 (urges regulation of racial epithets that do not involve face-to-face encounters, where victim is captive audience); id. at $451 \mathrm{n.85}$ (argues that fighting words include not only those addressed face-to-face, as under current doctrine, but should "be expanded in the case of racist verbal assaults to include those words that are intentionally spoken in the presence of members of the denigrated group"); id. at $463 \mathrm{n} .119$, $464 \mathrm{n} .120$ (endorses regulation of group defamation); id. at $481 \mathrm{n.169}$ ("Mari Matsuda has made a more radical venture, which 1 believe may well in the long run prove more satisfactory [than Lawrence's own proposals]. She calls for a doctrinal change that would involve an explicit content-based rejection of narrowly defined racist speech ...."). 
The rationales that Professor Lawrence advances for the regulations he endorses are so open-ended that, if accepted, they would appear to warrant the prohibition of all racist speech, and thereby would cut to the core of our system of free expression.

Although Professor Lawrence's specific proposed code appears relatively modest, his supporting rationales depend on nothing less immodest than the abrogation of the traditional distinctions between speech and conduct and between state action and private action. He equates private racist speech with governmental racist conduct. ${ }^{28}$ This approach offers no principled way to confine racist speech regulations to the particular contours of the Stanford code, or indeed to any particular contours at all. Professor Lawrence apparently acknowledges that, if accepted, his theories could warrant the prohibition of all private racist speech. ${ }^{29}$ Moreover, although he stresses the particular evils of racism, ${ }^{30}$ he also says that "much of my analysis applies to violent pornography and homophobic hate speech." 31 Thus, Professor Lawrence himself demonstrates that traditional civil libertarians are hardly paranoiac when we fear that any specific, seemingly modest proposal to regulate speech may in fact represent the proverbial "thin edge of the wedge" for initiating broader regulations.

As just explained, the relatively narrow Stanford code that Professor Lawrence endorses is incongruous with his broad theoretical rationale. The Stanford code also is at odds with Professor Lawrence's pragmatic rationale. The harins of racist speech that he seeks to redress largely remain untouched by the rule. For example, Professor Lawrence movingly recounts the pain suffered by his sister's family as a result of racist expression, ${ }^{32}$ as well as the anxiety he endured as a boy even from the

28. See Lawrence, at $438-49$.

29. See id. at 449 ("This precedent [Brown v. Board of Educ., 347 U.S. 483 (1954), and its progeny] may not mean that we should advocate the government regulation of all racist speech ....").

30. For example, Lawrence argues that racist speech and conduct are unique because of the direct link between speech or act and harm:

I do not contend that all conduct with an expressive component should be treated as unprotected speech. To the contrary, my suggestion that racist conduct amounts to speech is premised upon a unique characteristic of racism-namely its reliance upon the defamatory message of white supremacy to achieve its injurious purpose.

Id. at 440 n.42.

It is difficult to understand how racism is unique in terms of the asserted link between its message and its harm. Surely the same connection would exist between any form of group hatred and its resulting harm. For example, sexism relies on the message of male supremacy; homophobia relies on the message of heterosexual supremacy.

31. Id. at 436 n.27. See also supra note 27.

32. See Lawrence, at 459-61. 
possibility of racist expression. ${ }^{33}$ Yet the Stanford code clearly would not apply to any of the unspoken racist expressions that may lurk beneath the surface of much parlance in American life. Moreover, the regulation also would not apply unless the speech was directly targeted at a specific victim. ${ }^{34}$ Therefore, it would not have relieved Professor Lawrence or his family of the traumas they experienced. Furthermore, the Stanford code would not address the racist incident at Stanford that led to its adoption. ${ }^{35}$ Likewise, many additional campus racist incidents catalogued by Professor Lawrence and others would be beyond the scope of the Stanford code.

Two problems arise from the disharmony between the breadth of the racist speech regulations endorsed by Professor Lawrence and the harm that inspires them. First, this disparity underscores the rules' ineffectiveness. The regulations do not even address much of racist speech, let alone the innumerable other manifestations of racism which-as Professor Lawrence himself stresses ${ }^{36}$ - pervade our society. Second, this disharmony encourages the proponents of hate speech regulations to seek to narrow the gap between the underlying problem and their favored solution by recommending broader regulations. For example, Professor Mari Matsuda recently proposed a substantially more restrictive hate speech regulation on the theory that such a regulation is needed to redress the harm suffered by hate speech victims. ${ }^{37}$ Professor Lawrence has indicated his approval of Professor Matsuda's approach. ${ }^{38}$ And the wedge widens.

This Article attempts to bridge some of the gaps that Professor Lawrence believes separate advocates of equality from advocates of free speech. It shows that-insofar as proponents of hate speech regulations endorse relatively narrow rules that encompass only a limited category of racist expression-these gaps are not that significant in practical effect. It also demonstrates that the first and fourteenth amendments are allies rather than antagonists. Most importantly, this Article maintains that equality will be served most effectively by continuing to apply traditional,

33. Id. at $482-83$.

34. See infra text accompanying note 197 (quoting Stanford code).

35. See Gottlieb, supra note 4, at 3 (Professor Thomas Grey, who drafted the Stanford code, said "his rule probably wouldn't apply to one of the most publicized racial incidents at Stanford, when a white student left on a black student's door a poster of Beethoven drawn as a black caricature."). The broader variation of the Stanford code which Professor Lawrence endorsed, see Lawrence, at $450 \mathrm{n} .82$, apparently would have applied to this Stanford incident, see id. at $456 \mathrm{n} .101$, but not to the incident endured by his sister or to his boyhood ordeal.

36. See Lawrence, at 467-71. See, e.g., id. at 468 ("Racism is ubiquitous. We are all racists.").

37. See Matsuda, supra note 13.

38. See Lawrence, at 481 n.169. 
speech-protective precepts to racist speech, because a robust freedom of speech ultimately is necessary to combat racial discrimination. Professor Lawrence points out that free speech values as well as equality values may be promoted by regulating certain verbal harassment, and retarded by not regulating it. ${ }^{39}$ But it also must be recognized that equality values may be promoted most effectively by not regulating certain hate speech and retarded by regulating it. 40

Part I of this Article demonstrates that some traditional civil libertarians agree with Professor Lawrence's point that some speech amounts to verbal assault or harassment and may be subject to government regulation. Part II shows that Professor Lawrence's conception of regulable racist speech is broader than that permitted by established constitutional doctrine and would endanger fundamental free speech values. Part III explores the even greater danger to free speech values posed by Professor Lawrence's expansive rationales. ${ }^{41}$ Of primary importance, Part III exposes the flaws in Professor Lawrence's major argument-the argument that Brown v. Board of Education ${ }^{42}$ and other decisions that invalidate governmental racist conduct somehow legitimize regulation of non-governmental racist speech.

Notwithstanding my differences with Professor Lawrence about the boundaries of regulable racist expression, it is important to place these differences in proper perspective. Even the racist speech that he would regulate constitutes only a small fraction of all racist speech. Thus, most racist expression would remain untouched under both Professor Lawrence's approach and the approach traditionally endorsed by civil libertarians and the Supreme Court. More importantly, as Part IV discusses, Professor Lawrence's proposal would not effectively address the underlying problem of racism itself, of which racist speech is a symptom. Part IV shows that suppressing racist speech could even aggravate racially discriminatory attitudes. Thus, the goals of free speech and of eradicating racism are not incompatible, as Professor Lawrence sometimes suggests. ${ }^{43}$ Rather, as he also recognizes, ${ }^{44}$ these goals are mutually reinforcing. Although these points focus on Professor Lawrence's specific proposal, they apply as well to all other proposals to censor hate speech.

39. See Lawrence, at 437,453 n. $92,455,458$.

40. See infra text accompanying notes 365-96.

41. See supra notes 27-31.

42. 347 U.S. 483 (1954).

43. See supra notes 18-19.

44. See id. 
Finally, Part V maintains that we should channel our efforts toward devising means to combat racism that are consistent with the first amendment. This method ultimately will be more effective than censorship in promoting both equality and free speech. The resurgence of racist expression on American campuses has sparked a revitalized national dedication to promoting racial equality on college campuses and throughout our society and the forging of creative strategies for doing so. ${ }^{45}$ In order to counter racist speech, Professor Lawrence urges us to "think creatively as lawyers." 46 But if we are to understand and eradicate the complex root causes of racial discrimmation, then we must think creatively as more than just lawyers. ${ }^{47}$ We must draw upon the insights and skills of educators, sociologists, and psychologists. To draft legal rules that address only one manifestation of these deeper problems of racial inequality is at best ineffective, and at worst counterproductive.

\section{Some Limited Forms of Campus Hate Speech May Be REgulable UNDER CURRENT CONSTITUTIONAL DOCTRINE}

\section{A. General Constitutional Principles Applicable to Regulating Campus Hate Speech}

To put in proper perspective the specific points of disagreement between Professor Lawrence's analysis and traditional civil libertarian views, the points of agreement first should be noted. Professor Lawrence usefully rehearses the many shared understandings between advocates of a traditional doctrine, which protects much racist speech, and adyocates of various less protective regulations. Professor Lawrence acknowledges that there are strong reasons for sheltering even racist speech, in terms of reinforcing society's commitment to tolerance and mobilizing its opposition to intolerance. ${ }^{48}$ Consequently, he recognizes that to frame the debate in terms of a conflict between freedom of speech and the elimination of racism poses a false dichotomy. ${ }^{49}$ Accordingly, he urges civil libertarians to examine not just the substance of our position on racist speech, but

45. In response to the recent wave of racist expressions on campus, many universities have adopted programs designed to counter racism and to promote intergroup relations. See infra note 409. This development illustrates one of the advantages of refusing to censor hate speech: Society is motivated to counter the underlying biases that it manifests. See infra text accompanying notes 391 96.

46. Lawrence, at $\mathbf{4 8 0}$.

47. I owe this formulation to Ira Glasser, Executive Director of the ACLU (and a non-lawyer).

48. See Lawrence, at 436, 458 \& n. 105.

49. See id. at 435-36. 
also the way in which we enter the debate, to ensure that we condemn racist ideas at the same time as we defend the right to utter them..$^{50}$

There may be even more common ground between Professor Lawrence and the traditional civil libertarian position than he expressly acknowledges. In presenting the civil libertarian position as absolute and uni-focused, he oversimplifies and thereby distorts it. For example, as previously noted, Professor Lawrence sets up a "straw civil libertarian" who purportedly would afford absolute protection to all racist speechor at least "all racist speech that stops short of physical violence." 51 In fact, as evidenced by ACLU policies, traditional civil libertarians do not take such an extreme position. Indeed, some civil libertarians recently have charged that the ACLU has maintained an insufficiently absolutist position toward free speech in the context of campus hate speech, at the same time that Professor Lawrence, also a civil libertarian, charges that its position has been too absolutist. 52 Moreover, as a matter of both policy $^{53}$ and practice, ${ }^{54}$ the ACLU already condemns the ideas expressed by racist and other anti-civil libertarian speakers at the same time that it defends their right to utter them. Thus, contrary to Professor Lawrence's implication, ${ }^{55}$ such condemnation does not constitute an innovation.

Professor Lawrence also mischaracterizes traditional civil libertarians when he asserts that they tolerate the regulation of "garden variety" fighting words, but not racist fighting words. ${ }^{56}$ Some civil libertarians might agree with the Supreme Court's formerly stated view ${ }^{57}$ that a narrowly defined category of "fighting words" might not be constitutionally

50. See id. at $476-77$.

51. Id. at 449. See also id. at $438,457,461,473-74,476-77$.

52. See, e.g., Hentoff, If a Civil Liberties Union Can't Agree on Free Speech . . . Wash. Post, June 2, 1990, at A19, col. 1; Hentoff, The Different Faces of the ACLU, Wash. Post, March 31, 1990, at A27, col. 1; Rohde, Any Limitations Are Bound to Violate the First Amendment, Los Angeles Daily J., July 19, 1990, at 6, col. 4 ("I urge the California chapters of the ACLU to withdraw their new policy [permitting narrow regulations on campus hate speech] and replace it with something that's worked for nearly 200 years-the First Amendment.").

53. See ACLU Policy Guide, supra note 11, at Policy No. 46. The Policy states that: "[T]he democratic standards in which the ACLU believes and for which it fights run directly counter to the philosophy of the Klan and other ultra-right groups"; therefore, the ACLU should deal "with the difficult dilemma of having to defend the civil liberties of groups whose activities do fundamental injury to civil liberties" [by] vigorously present[ing] its opposing views "while defending the group's right to speak." See also id. at Policy No. 312.

54. See infra notes 338-55.

55. See Lawrence, at $476-81$.

56. Id. at $436-37$.

57. But see infrá text accompanying notes 116-31 (Court has construed fighting words exception to frec speech protection so narrowly that some scholars believe there no longer is such an exception). 
protected. ${ }^{58}$ Other civil libertarians maintain that "fighting words" should not be excluded from first amendment protection. ${ }^{59}$ They all agree, however, that racist fighting words should receive the same degree of protection (or nonprotection) as other fighting words.

Consistent with Professor Lawrence's free speech concerns, the category of racist speech he seeks to regulate under the Stanford code ${ }^{60}$ is relatively narrow compared to other campus hate speech rules. ${ }^{61}$ In important respects, this proposal overlaps with the traditional civil libertarian position. On the end of the spectrum where speech is constitutionally protected, Professor Lawrence agrees ${ }^{62}$ with courts and traditional civil libertarians that the first amendment should protect racist speech in a Skokie-type context. ${ }^{63}$ The essentials of a Skokie-type setting are that the offensive speech occurs in a public place and the event is announced in advance. Hence, the offensive speech can be either avoided or countered by opposing speech. Traditional civil libertarians

58. See T. EMERson, The System OF Free EXPRession 337-38 (1970) (" '[F]ighting words' can be considered the equivalent of knocking a chip off the shoulder-the traditional symbolic act that puts the parties in the role of physical combatants."); L. TRIBE, AMERICAN CONSTITUTIONAL LAw $\S 12-10$, at 852-53 (2d ed. 1988) ("[I]t is not difficult to recognize the genuine dilemma that law enforcement officers may confront when violence is incipient; although free speech would be suppressed, silencing the speaker is certainly preferable to a blood bath.").

59. See, e.g., F. HAIMAN, SPEech AND LAW IN A FREe SocietY (1981). Haiman states that: [I]t is my contention that in all of the circumstances in which antagonistic crowds or individuals respond or threaten to respond violently to communicators, the audience should be held responsible for its behavior, and not the speaker .... [V]iolent reaction, by definition, is born in the psyche of the respondent. The idea to attack the communicator is not implanted or urged by the speaker, as might an idea to commit illegal acts be initiated and advocated by one who incites a supportive audience....

... [I]f hostile audiences are not held responsible for their own behavior . . . they will soon learn that they have the power to exercise a "heckler's veto" over the speech of their antagonists.

Id. at 258; see also id. at 20-23, 132-35, 253-54, 256-58.

60. See infra text accompanying note 197.

61. For example, the Stanford code applies only to intentionally insulting words "addressed directly" to an individual or a small number of individuals. See infra text accompanying note 197. In contrast, the Michigan rule which was recently held to violate the first amendment, see infra text accompanying notes 208-12, did not require either that the penalized words be intentionally insulting or that they be addressed to specific individuals. Moreover, the Michigan rule originally proscribed speech that "[c]reates an intimidating, hostile, or demeaning environment." See infra note 203. The same overbroad, vague language is contained in the rule recently adopted by the University of Wisconsin Board of Regents. See UWS 17.06(2)(a)(2) (effective Sept. 1, 1990).

62. See Lawrence, at $457 \&$ n. 103.

63. The reference is to an American neo-Nazi group's efforts, in 1977-78, to gain permission to demonstrate in Skokie, Illinois, a community with a large Jewish population, including many Holocaust survivors. For the judicial opinions rejecting arguments that Skokie residents should be protected from such personally odious expressions, see, e.g., Collin v. Smith, 578 F.2d 1197, 1205-07 (7th Cir.), cert. denied, 439 U.S. 916 (1978); Village of Skokie v. National Socialist Party, 69 Ill. 2d $605,612-18,373$ N.E.2d 21, 23-25 (1978). For an excellent account of both the specific Skokie controversy and the general issues it raised, see A. NEIER, DEfENDING MY ENEMY: AMERICAN Nazis, The Skokie CaSe, and the Risks Of Freedom (1979). 
recognize that this speech causes psychic pain. We nonetheless agree with the decision of the Seventh Circuit in Skokie ${ }^{64}$ that this pain is a necessary price for a system of free expression, which ultimately redounds to the benefit of racial and other minorities.65 Professor Lawrence apparently shares this view.

On the other end of the spectrum, where expression may be prohibited, traditional civil libertarians agree with Professor Lawrence that the first amendment should not necessarily protect targeted individual harassment just because it happens to use the vehicle of speech. The ACLU maintains this non-absolutist position, for example, with regard to sexually harassing speech on campus or in the workplace. The ACLU recently adopted a pohicy that specifically addresses racist harassment on campus, ${ }^{66}$ and it previously had adopted analogous policies concerning sexual harassment on campus and in the workplace. These earlier policies recognize that unlawful sex discrimination can consist of words specifically directed to a particular individual-words that undermine the individual's continued ability to function as a student or employee. With regard to sexual harassment on campus, ACLU policy provides:

College[s] and universities should take those steps necessary to prevent the abuse of power which occurs ... where a pattern and practice of sexual conduct or sexually demeaning or derogatory comments is directed at a specific student or gender [and] has definable consequences for the student that demonstrably hinders her or his learning experience as a student. This policy does not extend to verbal harassment that has no other effect on its recipient than to create an unpleasant learning environment. ${ }^{67}$

As the last sentence of this policy emphasizes, the ACLU demands evidence that harassing speech causes verifiable harm that directly interferes with a student's education in a more tangible, specific manner than creating an "unpleasant environment." A parallel limiting concept is embodied in the ACLU's definition of verbal sexual harassment in the workplace as:

[E]xpression ... directed at a specific employee [that] has definable consequences for the individual victim that demonstrably hinders or completely prevents her or his continuing to function as an employee.

64. Collin, 578 F.2d at 1197.

65. For an elaboration of this point, see infra text accompanying notes 408-34.

I use the term "minorities" rather than "people of color" because the groups I intend to signify include those differentiated by characteristics other than race or ethnicity, such as religion, sexual orientation, or physical disability. I recognize, however, that the term "minorities" may "impl[y] a certain delegitimacy in a majoritarian system" and in fact describes groups that in the aggregate are a majority. Williams, Alchemical Notes: Reconstructing Ideals From Deconstructed Rights, 22 HARV. C.R.-C.L. L. Rev. 40I, 404 n.4 (1987).

66. See supra note 11.

67. ACLU Policy Guide, supra note 11, at Policy No. 72; see also supra note 11 and Appendix. 
Ordinarily these would be the sort of consequences that could give rise to an action for civil damages or a claim for workers' compensation, unemployment compensation or sick leave. This policy does not extend to verbal harassment that has no other effect on its recipient than to create an unpleasant working environment. ${ }^{68}$

These ACLU policies recognize that conduct that infringes on the right to equal educational (or employment) opportunities, regardless of gender (or other invidious classifications) should not be condoned simply because it includes expressive elements.

To be sure, there is no clear boundary between speech that "demonstrably hinders" a learning (or working) experience and speech that "creates an unpleasant learning" (or working) environment. Accordingly, even civil libertarians who agree that this is the appropriate line to draw between unprotected and protected speech in the harassment context still would be expected to disagree about whether particular speech fell on one side of this boundary or the other. Moreover, some civil libertarians might endorse broader definitions of unprotected harassing speech, ${ }^{69}$ whereas others might insist on narrower definitions. ${ }^{70}$ However, the essential underlying point still stands: In the analogous context of regulating sexually harassing speech, traditional civil libertarians share what Professor Lawrence describes as a "moderate" perspective with regard to racially harassing speech-i.e., that such speech should be neither absolutely protected nor absolutely prohibited. ${ }^{71}$

68. ACLU Policy Guide, supra note 11, at Policy No. 316.

69. See supra note 11.

70. See, e.g., F. HAIMAN, supra note 59, at 148-56 (would limit sanctions for verbal infiction of emotional distress to cases of injury through intentional factual misrepresentation).

71. See C. Lawrence, Presentation at ACLU Biennial Conference, supra note $f$, at 7 . The Supreme Court applies a more searching degree of scrutiny to race-based discrimination than to gender-based discrimination. Compare Korematsu v. United States, 323 U.S. 214 (1944) ("strict scrutiny" standard applies to race discrimination claims) with Craig v. Boren, 429 U.S. 190 (1976) ("intermediate scrutiny" standard applies to gender discrimination claims). Moreover, at least since Brown v. Board of Educ., 347 U.S. 483 (1954), the Supreme Court consistently has enforced the equal protection clause with particular vigor in the context of promoting racial equality in education. See Bob Jones Univ. v. United States, 461 U.S. 574, 593 (1983) ("An unbroken line of cases following Brown v. Board of Education establishes beyond doubt this Court's view that racial discrimination in education violates a most fundamental national public policy, as well as rights of individuals."). Therefore, the ACLU rationale for treating some verbal harassment of students as prohibited gender-based discrimination, coupled with Supreme Court decisions, warrants treating some expressive conduct as prohibited race-based discrimination.

Professor Lawrence inexplicably asserts that "the suggestion" that the ACLU "adopt a policy concerning racist speech on campus .... [t] hus far ... has not found widespread support within the ranks of the organization." Lawrence, at 478 n.163. He cites no support for this assertion, nor is there any. Since no poll has been undertaken of the approximately 300,000 members who constitute the ACLU's "ranks," it would be inpossible to prove any generalization about their position on the indicated suggestion. Moreover, three ACLU affiliates have adopted a policy that does not oppose campus regulations of certain verbal harassment. See supra note 11 and Appendix. 
Specifically in the context of racist speech, the ACLU has recognized that otherwise punishable conduct should not be shielded simply because it relies in part on words. Some examples were provided by ACLU President Norman Dorsen:

During the Skokie episode, the ACLU refused to defend a Nazi who was prosecuted for offering a cash bounty for killing a Jew. The reward linked the speech to action in an impermissible way. Nor would we defend a Nazi (or anyone else) whose speech interfered with a Jewish religious service, or who said, "There's a Jew; let's get him."72

The foregoing ACLU positions are informed by established principles that govern the protectibility of speech. Under these principles, speech may be regulated if it is an essential element of violent or unlawful conduct, ${ }^{73}$ if it is likely to cause an immediate injury by its very utterance, ${ }^{74}$ and if it is addressed to a "captive audience" unable to avoid assaultive messages. ${ }^{75}$ It should be stressed that each of these criteria is ambiguous and difficult to apply in particular situations. Accordingly, the ACLU would insist that these exceptions to free speech be strictly construed and would probably find them to be satisfied only in rare factual circumstances. ${ }^{76}$ Nevertheless, ACLU policies expressly recognize that if certain speech fits within these narrow parameters, then it could be regulable. ${ }^{77}$

72. Dorsen, Is There a Right to Stop Offensive Speech? The Case of the Nazis in Skokie, in Civil Liberties IN Conflict 133-34 (L. Gostin ed. 1988); see also A. Neier, supra note 63, at 8990.

73. The law may sanction crimes and torts accomplished by words without violating the first amendment, although it is sometimes hard to distinguish between protected expression advocating the commission of criminal or civil offenses and unproteeted expression that actually constitutes an element of such offenses. See generally Greenawalt, Speech and Crime, 1980 AM. B. Found. RES. J. 645 (examining the tension between the proteetive approach to advocacy of crime taken by the Supreme Court and criminal code solicitation provisions). Crimes and torts that may consist primarily of words include bribery, fraud, and libel. See infra note 321 (sex-designated advertisements for jobs or housing are unprotected, as integral elements of proscribed discriminatory conduct).

74. This category is illustrated by Oliver Wendell Holmes' proverbial example of "falsely shouting fire in a theater and causing a panic." Schenck v. United States, 249 U.S. 47, 52 (1919). This theory also is invoked to justify regulating "fighting words" and group defamation. See infra text accompanying notes 116-51 \& 165-75. Although the ACLU has no policy expressly addressing the fighting words doctrine, it explicitly rejects group defamation laws as inconsistent with the first amendment. See ACLU Policy Guide, supra note 11, at Policy No. 6(c).

75. See L. TRIBE, supra note $58, \S 12-18$, at 941.

76. There is no basis for Professor Lawrence's implication that traditional civil libertarians might support "less protection [for captive audiences] when they are held captive by racist speakers." Lawrence, at 438. Compare supra text accompanying notes 56-59 (Professor Lawrence incorrectly suggests that traditional civil libertarians would support less constitutional protection for racist fighting words than for other fighting words).

77. Regarding speech that is an essential element of unlawful conduct, the ACLU Policy Guide, supra note 11, at Policy No. 16, states that, "[T]here is ... [al need for the regulation of selling practices to minimize fraud, deception, and misrepresentations.... If the sale or transaction 
The captive audience concept in particular is an elusive and challenging one to apply. As Professor Tribe cautioned, this concept "is dangerously encompassing, and the Court has properly been reluctant to accept its implications whenever a regulation is not content-neutral."78 Noting that we are "often 'captives' outside the sanctuary of the home and subject to objectionable speech," 79 the Court has ruled that, in public places, we bear the burden of averting our attention from expression we find offensive. ${ }^{80}$ Otherwise, the Court explained, "a majority [could] silence dissidents simply as a matter of personal predilections."81 The Court has been less reluctant to apply the captive audience concept to

is one that can be validly regulated or prohibited, then communications that are an integral part of such a sale or transaction can be regulated."

Regarding speech that can cause an immediate injury by its very utterance, see ACLU Policy Guide, supra note 11, at Policy No. 6 (accepts limitations on expression that creates "clear and present danger" of immediate unlawful action); id. at Policy No. 37 (recognizing that, under strictly limited circumstances, certain lawsuits may be brought for libel and invasion of privacy through speech without violating first amendment).

Regarding captive audiences, the ACLU Policy Guide, supra note 11, at Policy No. 43, states that:

[T] he First Amendment is not inconsistent with reasonable regulations desigued to restrict sensory intrusions so intense as to be assaultive. Reasonable regulations are those that apply only to time, place and manner without regard to content. ... What constitutes a "reasonable" regulation will necessarily vary depending upon such factors as (1) the size of the ... area involved, (2) the duration [or] frequency with which an individual is in the area ...., or (3) the extent to which alternatives exist so that the individual can reasonably be called upon to avoid the area. ... Assaultive sensory intrusions are those that are objectionable to the average person because of an excessive degree of intensity, e.g., volume or brightness, and which cannot be avoided.

In larger public spaces... all communication is permitted unless it interferes with the primary purpose of the space. ...

In open public areas ... people are able to move away from communication which they consider offensive. So long as there is ample public space[ ] where communication is unrestricted, the government may creat[sic] and maintain reasonably limited sanctuaries in public places where people can go for quiet and contemplation.

78. L. TR1BE, supra note $58, \S 12-19$, at $949-50$ n.24. For an argument that the captive audience concept should be construed narrowly, see Haiman, Speech $v$. Privacy: Is There a Right Not to be Spoken To?, 67 Nw. U.L. REV. 153, 184 (1972). Haiman argues that:

[H]uman beings have a significant ability mentally to reject many assaultive stimuli. The process known as "selective perception" enables us to generally choose what we wish to assimilate from the multitude of sensory bombardments surrounding us. . . [W]e also have a strong tendency to screen out or distort messages that are inconsistent with ... our current beliefs.

Given these tendencies .... . one might argue that the possibilities of unwelcome messages penetrating the psychological armor of unwilling audiences are so small that we ought to be worrying more about how to help unpopular communicators get through to reluctant listeners than how to give further protection from speech to those who already know too well how to isolate themselves from alien ideas.

79. Rowan v. United States Post Office Dep't, 397 U.S. 728, 738 (1970).

80. See, e.g., Erznoznik v. Jacksonville, 422 U.S. 205, 210 (1975) (ordinance banning movies showing nudity on drive-in screens visible from street could not be upheld to protect sensibilities of involuntary passers-by); Cohen v. California, 403 U.S. 15, 21 (1971) (Individuals offended by expression on defendant's jacket worn in courthouse corridor "could effectively avoid further bombardment of their sensibilities simply by averting their eyes.").

81. Cohen, 403 U.S. at 21. 
private homes. ${ }^{82}$ However, the Court has held that even in the home, free speech values may outweigh privacy concerns, requiring individuals to receive certain unwanted communications. ${ }^{83}$

The Court's application of the captive audience doctrine illustrates the general notion that an important factor in determining the protection granted to speech is the place where it occurs. ${ }^{84}$ At one extreme, certain public places-such as public parks-have been deemed "public forums," where freedom of expression should be especially protected. ${ }^{85}$ At the other extreme, some private domains-such as residential buildings-have been deemed places where freedom of expression should be subject to restriction in order to guard the occupants' privacy and tranquillity. ${ }^{86}$ In between these two poles, certain public areas might be held not to be public forums because the people who occupy them might be viewed as "captive." 87

The foregoing principles that govern the permissibility of speech regulations in general should guide our analysis of the permissibility of particular speech regulations in the academic setting. The Supreme Court has declared that within the academic environment freedom of expression should receive heightened protection ${ }^{88}$ and that "a university

82. See, e.g., Rowan, 397 U.S. at 737 (upholding addressee's statutory right to compel mailer of material which is deemed erotic, at addressee's sole discretion, to remove addressee's name from mailing list and stop all future mailings); Kovacs v. Cooper, 336 U.S. 77, 87 (1949) (upholding ordinance proscribing use of sound trucks in "loud and raucous" manner, in part because individual in his home is "practically helpless to escape" noise).

83. See Consolidated Edison Co. v. Public Serv. Comm'n, 447 U.S. 530, 542 (1980) (Court rejected captive audience objection to utility company's insertion of materials advocating nuclear power development in its billings, reasoning that customers could "escape exposure to the objectionable material simply by transferring the bill insert from envelope to wastebasket").

84. See G. Stone, L. Seidman, C. Sunstein \& M. Tushnet, Constitutional Law 1177 1201, 1267-73 (1986).

85. See L. TRIBE, supra note $58, \S 12-20$, at $955-65$.

86. See supra note 82; see also Carey v. Brown, 447 U.S. 455, 471 (1980) ("Preserving the sanctity of the home, the one retreat to which men and women can repair to escape from the tribulations of their daily pursuits, is surely an important value. . . Protecting the well-being, tranquility, and privacy of the home is certainly of the highest order in a free and civilized society.").

87. See Lehman v. City of Shaker Heights, 418 U.S. 298, 302 (1974) (plurality opinion) (transit system advertising space not public forums, because users were captive audience); id. at 306-07 (Douglas, J., concurring). But see Frisby v. Schultz, 487 U.S. 474, 480 (1988) (residential neighborhood strects are public forum).

88. See, e.g., Sweeney v. New Hampshire, 354 U.S. 234, 250 (1957) ("Teachers and students must always remain free to inquire, to study and to evaluate, to gain new maturity and understanding; otherwise our civilization will stagnate and die."). See also Keyishian v. Board of Regents, 385 U.S. 589, 603 (1967) (the classroom is "peculiarly the marketplace of ideas"); Shelton v. Tucker, 364 U.S. 479, 487 (1960) (nowhere are constitutional freedoms more vital than in American schools).

In University of Pa. v. EEOC, 110 S. Ct. 577 (1990), the Court said that these earlier cases did not protect a university from disclosing to the EEOC confidential pecr review materials regarding the tenure candidacy of a former faculty member who allegedly had suffered race- and gender-based discrimination. However, the Court acknowledged "the crucial role universities play in the dissemi- 
campus ... possesses many of the characteristics of a traditional public forum." 89 These considerations would suggest that hate speech should receive special protection within the university comnunity. Conversely, Professor Mari Matsuda argues that equahity guarantees and other principles that night weigh ni favor of prohibiting racist speech also are particularly important in the academic context.90

The appropriate analysis is more complex than either set of generalizations assumes. In weighing the constitutional concerns of free speech, equality, and privacy that hate speech regulations implicate, decisionmakers niust take into account the particular context within the university in which the speech occurs. For example, the Court's generalizations about the heightened protection due free speech in the academic world certainly are apphicable to sonie campus areas, such as parks, nialls, or other traditional gathering places. The generalizations, however, may not be applicable to other areas, such as students' dormitory rooms. These roonis constitute the students' honies. Accordingly, under establislied free speecli tenets, students slould have the right to avoid being exposed to others' expression by seeking refuge in their rooms. ${ }^{91}$

Some areas on canipus present difficult problenis concerning the appropriate level of speech protection because they share characteristics of botli private lomes and public forums. For exaniple, one could argue that hallways, conimon roonis, and other conimon areas in dormitory buildings constitute extensions of the mdividual students' roonis. ${ }^{92}$ On the other hand, one could argue that these commion areas constitute traditional gathering places and should be regarded as public fornnis, open to expressive activities at least by all dormitory residents if not by

nation of ideas in our society," id. at 585, and it reaffirmed an "academic-freedom right against governmental attempts to infiuence the content of academic speech," id. at 586.

89. Cornelius v. NAACP Legal Defense and Educ. Fund, 473 U.S. 788, 803 (1985); see also Widmar v. Vincent, 454 U.S. 263, $267 \&$ n.5 (1981) (through policy of accommodating students' meetings, public university crcated open forum for student groups).

90. See Matsuda, supra note 13. Professor Matsuda states that:

Many of the new adults who come to live and study at the major universities are away from home for the first time, and at a vulnerable stage of psychological development. Students are particularly dependent on the university for community, for intellectual development, and for self-definition. Official tolerance of racist speech in this setting is more harmful than generalized tolerance in the community-at-large. It is harmful to student perpetrators in that it is a lesson in getting-away-with-it that will have lifelong repercussions. It is harmful to targets, who perceive the university as taking sides through inaction, and who are left to their own resources in coping with the damage wrought. Finally, it is a harm to the goals of inclusion, education, development of knowledge, and ethics that universities exist and stand for. Lessons of cynicism and hate replace lessons in critical thought and inquiry.

Id. at 2370-71 (footnotes omitted).

91. See supra text accompanying notes 82-86.

92. Professor Lawrence so argues, see Lawrence, at 456. 
the broader community. Such an argument would derive general support from Supreme Court decisions that uphold the free speech rights of demonstrators in residential neighborhoods on the theory that an individual resident's right of stopping "the flow of information into [his or her] household" does not allow him to impede the flow of this same information to his neighbors. ${ }^{93}$ The Supreme Court, however, recently declined to resolve the specific issue of whether university dormitories constitute public forums for free speech purposes. ${ }^{94}$

Even in the areas of the university reserved for academic activities, such as classrooms, the calculus to determine the level of speech protection is complex. On the one hand, the classroom is the quintessential "marketplace of ideas,"9s which should be open to the vigorous and robust exchange of even insulting or offensive words, on the theory that such an exchange ultimately will benefit not only the academic community, but also the larger community, in its pursuit of knowledge and understanding. 96

On the other hand, some minority students ${ }^{97}$ contend that in the long run, the academic dialogue might be stultifled rather than stimulated by the inclusion of racist speech. They maintain that such speech not only interferes with equal educational opportunities, but also deters the exercise of other freedoms, including those secured by the first

93. Organization for a Better Austin v. Keefe, 402 U.S. 415, 420 (1971) (invalidating injunction against leafletting in suburban residential areas as unjustified prior restraint); see also Frisby $v$. Schultz, 487 U.S. 474, 485 (1988) (in upholding ordinance regulating residential picketing, Court stressed that it prohibited only focused picketing in front of single residence; ×no broader-gauged picketing was prohibited).

94. See Board of Trustees v. Fox, 109 S. Ct. 3028, 3031 n.2 (1989). The district court in the same case had characterized these dormitories as "limited public forums." Fox v. Board of Trustees, 649 F. Supp. 1393, 1401 (N.D.N.Y. 1986).

95. Keyishian v. Board of Regents, 385 U.S. 589, 603 (1967).

96. See Schmidt, Freedom of Thought: A Principle in Peril?, Yale Alumni Mag., Oct. 1989, at 66 ("On some other campuses in this country, values of civility and community have been offered by some as paramount values of the university, even to the point of superseding freedom of expression. Such a view is wrong in principle, and, if extended, disastrous to freedom of thought.").

97. It should be stressed that not all minorities take this position, or support campus hate speech regulations. See supra note 21 . In any event, even if a majority of a particular group supported a certain position, this would not necessarily mean that the position was correet in any sense, including in the sense that it advanced the group's self-interest. Justice Brennan, in a dissenting opinion in Michigan Dep't of Statc Police v. Sitz, 110 S. Ct. 2481, 2490 (1990), recently made this point in another constitutional context:

I would hazard a guess that today's opinion will be received favorably by a majority of our society, who would willingly suffer the minimal intrusion of a sobriety checkpoint stop in order to prevent drunk driving. But consensus that a particular law enforcement technique serves a laudable purpose has never been the touchstone of constitutional analysis. ... ... "Moved by whatever momentary evil has aroused their fears, officials-perhaps even supported by a majority of citizens-may be tempted to conduct searches that sacrifice the liberty of each citizen to assuage the perceived evil."

Id. (quoting Olmstead v. United States, 277 U.S. 438, 478 (1928) (Brandeis, J., dissenting)). 
amendment.98 Professor Lawrence argues that, as a consequence of hate speech, minority students are deprived of the opportunity to participate in the academic interchange, and that the exchange is impoverished by their exclusion. ${ }^{99}$ It must be emphasized, though, that expression subject to regulation on this rationale would have to be narrowly defined in order to protect the free flow of ideas that is vital to the academic community; thus, much expression would remain unregulated-expression which could be sufficiently upsetting to interfere with students' educational opportunities. 100

Another factor that might weigh in favor of imposing some regulations on speech in class is that students arguably constitute a captive audience. ${ }^{101}$ This characterization is especially apt when the course is required and class attendance is mandatory. Likewise, the case for regulation becomes more compelling the more power the racist speaker wields over the audience. ${ }^{102}$ For exainple, the law should afford students

98. See Letter from David Lee (a Stanford law student writing on behalf of Asian Law Students Association, Black Law Students Association, Jewish Law Students Association, Native American Law Students Association and Asian American Students Association) to Student Conduct Legislative Council (May 8, 1989), reprinted in Stanford Univ. Campus Rep., May 10, 1989, at 13. Lee stated that:

[T] hose most concerned about having the [university rule] cover attacks against minority students that take the form of discriminatory speech are not advocating reduction in the freedom of speech. Rather, they are advocating more freedom of speech, more vigorous debate. . . . [R]acist speech [is] designed to silence the recipients of the speech, not to encourage them to debate. Racist speech silences its victims by warning them that they will suffer some kind of harm if they dare to speak up for their rights to work for economic success, to try to get a quality education, or to take part in the political process.

See also Matsuda, supra note 13, at 2337 ("In order to avoid receiving hate messages, victims have had to quit jobs, forgo education, lcave their homes, avoid certain public places, curtail their own exercise of speech rights, and otherwise modify their behavior and demeanor.").

99. See Lawrence, at $437,456,471$. Professor Lawrence also makes a related point that the marketplace of ideas is distorted, to the detriment of the entire community, by the inclusion of racist speech. See id. at 467-71.

100. See Grano, supra note 8. Grano stated that:

One of the harms posited in the University of Michigan case was that some students found the speech at issue so upsctting that they had difficulty concentrating on their studies. The same harm could be posited, of course, in many other circumstances. During the Vietnam War, for example, the frequent and often caustic antiwar protests, which sometimes even expressed support for those whom the United States was fighting, may have extremely upset students who had served in battle, who had lost family members or friends in the war, or who simply believed that an unwavering loyalty was owed to their country. Similarly, many students, especially on segregated campuses in the South, may have been deeply disturbed by the civil rights protests gripping the nation and many universities during the 1960 s.

Id. at 17.

101. Professor Lawrence so argnes. See Lawrence, at 456-57.

102. See, e.g., Contreras v. Crown Zellerbach Corp., 88 Wash. $2 d$ 735, 741, 565 P.2d 1173, 1176 (1977) (reversing lower court's dismissal of Mexican-American employce's suit claiming he had been subject to racist slurs on the job, the court noted, "[W] hen one in a position of authority, actual or apparent, over another has allegedly made racial slurs and jokes and comments, this abusive conduct gives added impetus to the claim"). 
special protection from racist insults directed at them by their professors. ${ }^{103}$

Even $\mathrm{i}_{\mathrm{i}}$ various areas of a university are not classified as public forums, and even if occupants of such areas are designated captive audiences, any speech regulations in these areas still would be invalid if they discriminated on the basis of a speaker's viewpoint. Viewpoint-based discrimination constitutes the most egregious form of censorship ${ }^{104}$ and almost always violates the first amendinent. ${ }^{105}$ Accordingly, viewpoint discrimination is proscribed even in regulations that govern non-public forum goverimient property ${ }^{106}$ and regulations that protect captive audiences. ${ }^{107}$

Many proposed or adopted campus hate speech regulations constitute unconstitutional discrimination against particular views, either as they are written or as they are applied. This is a constitutional defect of the rule advocated by Professor Lawrence, for exainple. ${ }^{108} \mathrm{He}$ endorsed a variation on the Stanford regulation that expressly would have ex-

The ACLU's policy endorsing restrictions on a limited category of verbal sexual harassment on campus is confined to situations that involve "tlie abuse of power." See supra text accompanying note 67.

103. Speech by professors or administrators of public universities might be distinguishable from that of otlier members of university communities on the ground that it is arguably government speecl, and hence subject to greater regulation. See infra text accompanying notes 299-302. However, faculty members and administrators have free speech rights of their own, which would weigh against government regulation. See Tinker v. Des Moines Indep. Community School Dist., 393 U.S. 503, 506 (1969); James v. Board of Educ., 461 F.2d. 566 (2d Cir 1972), cert. denied, 409 U.S. 1042 (1973); Russo v. Central School Dist. No. 1, 469 F.2d. 623 (2d Cir. 1972), cert. denied, 411 U.S. 392 (1973); Van Alstyne, The Specific Theory of Academic Freedom and the General Issue of Civil Lib. erty, in The CONCEPT of ACADEMIC Freedom 59 (E. Pincoffs ed. 1975); Van Alstyne, The Constitutional Rights of Teachers and Professors, 1970 DuxE L.J. 841. Moreover, university students should not necessarily view the speech of such individuals as representing the government's position, as opposed to that of the individuals. See generally Widmar v. Vincent, 454 U.S. 263 (1981) (public university students should recoguize that state does not necessarily endorse speech by sehool-approved student organization meeting on campus). In any event, both public and private universities should encourage all their employees to be sensitive to the feelings and concerns of minority group members and to voluntarily couch their speecls accordingly. See infra text accompanying notes 403 05.

104. See First Nat'1 Bank v. Bellotti, 435 U.S. 765, 785 (1978); Madison Joint School Dist. No. 8 v. Wisconsin Employment Relations Comm'n, 429 U.S. 167, 175-76 (1976).

105. See Members of the City Council v. Taxpayers for Vincent, 466 U.S. 789, 804 (1984) ("a desire . . . to exclude the expression of certain points of view from the marketplace of ideas" is "plainly illegitimate" absent a demonstrated compelling state interest).

106. See, e.g., United States v. Kokinda, 110 S. Ct. 3115, 3121 (1990); Comelius v. NAACP Legal Defense and Educ. Fund, 473 U.S. 788, 806 (1985); Perry Educ. Ass'n v. Perry Local Educators' Ass'n, 460 U.S. 37, 43 (1983).

107. See Lehman v. City of Shaker Heights, 418 U.S. 298, 305 (1974); American Booksellers Ass'n v. Hudnut, 771 F.2d 323, 333 (7th Cir. 1985), aff'd, 475 U.S. 1001 (1986).

108. See supra note 24. 
cluded speech directed at "dominant majority groups."109 Despite the absence of explicit viewpoint discrimination in the rule that Stanford adopted, the chair of the committee that propounded this rule indicated that, as applied, it would effect viewpoint discrimination. ${ }^{110}$ Professor Lawrence concedes that the Stanford code is facially content discriminatory, ${ }^{111}$ and, as apphed, probably viewpoint discriminatory as well. ${ }^{112}$

As the foregoing discussion illustrates, the question whether any particular racist speech should be subject to regulation is a fact-specific inquiry. ${ }^{113}$ We cannot define particular words as inherently off limits, but rather we must examine every word in the overall context in which it is uttered. ${ }^{114}$

\section{B. Particular Speech-Limiting Doctrines Potentially Applicable to Campus Hate Speech}

In addition to the foregoing general principles, Professor Lawrence and other proponents of campus hate speech regulation invoke three specific doctrines in an atteinpt to justify such rules: the fighting words doctrine; the tort of intentional infliction of einotional distress; and the tort of group defamation. ${ }^{115}$ As the following discussion shows, the Supreme

109. Lawrence, at $450 \mathrm{n} .82$. For the problems of equality and enforceability that this exception would cause, see infra note 387.

110. See Hentoff, Stanford and the Speech Police, Wash. Post, July 21, 1990, at A19, col. 1. Hentoff stated that:

During a debate in the Faculty Senate, Professor Michael Bratman offered a hypothetical: in an angry exchange with a white student, a black student calls him a "honky SOB." I assume, said Bratman, that language would be prohibited.

"No," said Professor [Robert] Rabin [a law professor who chairs the Student Conduct Legislative Council, which propounded the code]. The proposed speech standard takes the position, Rabin explained, that the white majority as a whole is not in as much need of protection from discriminatory harassing speech as are those who have suffered discrimination. "nigger.'"

"Calling a white a "honky," Rabin said, "is not the same as calling a black a

111. The prohibition against content bias, the suppression of expression about an entire subject, was an outgrowth of the core prohibition against viewpoint bias. See Stone, Restrictions on Speech Because of its Content: The Peculiar Case of Subject-Matter Restrictions, 46 U. CHI. L. REV. 81 (1978). See also infra note 246 (discussing presumptive unconstitutionality of content-based speech regulations).

112. See Lawrence, at 451 n.83.

113. See L. TR1BE, supra note $58, \S 12-10$, at $853-54$ (When government suppresses what would otherwisc be constitutionally protected speech because of imminent violence, "the result is necessarily scnsitive to even slight variations in the facts of the particular case.").

114. See id. $\$ 12-10$, at 850 (modern Court has rejected assumption of original "fighting words" doctrine, that certain words could be proscribed regardless of context in which they were used).

115. The University of Michigan based its rule on yet another approach, which focused on stigmatization and victimization of students, interference with academic efforts, and the creation of an intimidating or hostile educational environment. In Doe v. University of Mich., 721 F. Supp. 852 (E.D. Mich. 1989), this rule was held to violate the first amendment. Accordingly, some universities that had been considering a similar approach have apparently abandoned it in response to the Doe 
Court has recognized that each of these doctrines may well be inconsistent with frec speech principles. Therefore, these doctrines may not support any campus hate speech restrictions whatsoever. In any event, they at most would support only restrictions that are both narrowly drawn and narrowly applied.

1. Fighting Words. The fightimg words doctrine is the principal model for the Stanford code, which Professor Lawrence supports. ${ }^{116}$ However, this doctrine provides a constitutionally shaky foundation for several reasons: it has been substantially limited in scope and may no longer be good law; even if the Supreme Court were to apply a narrowed version of the doctrine, such an application would threaten free speech principles; and, as actually implemented, the fighting words doctrine suppresses protectible speech and entails the inherent danger of discriminatory application to speech by members of minority groups and dissidents.

Although the Court originally defined constitutionally regulable fighting words in fairly broad terms in Chaplinsky v. New Hampshire, ${ }^{117}$ subsequent decisions have narrowed the definition to such a point that the doctrine probably would not apply to any of the instances of campus racist speech that Professor Lawrence and others seek to regulate. As originally formulated in Chaplinsky, the fighting words doctrine excluded from first amendment protection 'insulting or 'fighting' words, those which by their very utterance inflict injury or tend to incite an immediate breach of the peace."118

In light of subsequent developments, it is significant to note that the first prong of Chaplinsky's fighting words definition, words "which by their very utterance inflict injury," was dictum. The Court's actual holding was that the state statute at issue was justified by the state's interest in preserving the public peace by prohibiting "words likely to cause an average addressee to fight."119 The Court stressed that "no words were forbidden except such as have a direct tendency to cause acts of violence

ruling. See Report of President's Ad Hoc Committee on Racial Harassment, University of Texas at Austin 17 (Nov. 27, 1989) [hereinafter University of Texas Reportl (authored by committee chaired by Mark G. Yudof, Dean and James A. Elkins Centennial Chair in Law, University of Texas School of Law) ("For all of the reasons identified by the [Doe] court, [this] Committee early on abandoned the idea of recommending a racial harassment policy grounded in the Michigan approach. After the court's decision, a number of other universities withdrew similar policies, thus corroborating the Committec's decision."). But see supra note 61 (University of Wisconsin adopted a rule similar to the one adopted by the University of Michigan). For a discussion of the constitutional flaws in the Michigan-Wisconsin approach, see infra notes 208-15 and accompanying text.

116. See Lawrence, at 450-51. See also infra text accompanying note 197.

117. 315 U.S. 568 (1942).

118. Id. at 572 (emphasis added).

119. Id. at 573 . 
by the person to whom, individually, [they are] addressed." 120 The Court also held that the statute had been applied appropriately to Mr. Chaplinsky, who had called a city marshal "a God damned racketeer" and "a dainned Fascist."121 It explained that these "epithets [are] likely to provoke the average person to retaliation, and thereby cause a breach of the peace." 122

In Gooding v. Wilson, the Court substantially narrowed Chaplinsky's definition of fighting words by bringing that definition into line with Chaplinsky's actual holding. ${ }^{123}$ In Gooding, as well as in every subsequent fighting words case, the Court disregarded the dictum in which the first prong of Chaplinsky's definition was set forth and treated only those words that "tend to incite an immediate breach of the peace" as fighting words. Consistent with this narrowed definition, the Court has invalidated regulations that hold certain words to be per se proscribable and insisted that each challenged utterance be evaluated contextually. ${ }^{124}$ Thus, under the Court's current view, even facially vahd laws that restrict fighting words may be applied constitutionally only in circumstances where their utterance alinost certainly will lead to immediate violence. ${ }^{125}$ Professor Tribe described this doctrinal development as, in effect, incorporating the clear and present danger test into the fighting words doctrine. ${ }^{126}$

120. Id.

121. Id. at 569.

122. Id. at 574 .

123. 405 U.S. 518,523 (1972) (where appellant had said to police officers, "White son of a bitch, I'll kill you," "You son of a bitch, I'll choke you to death," and "You son of a bitch, if you ever put your hands on me again, I'll cut you all to pieces," Court reversed conviction under law that it found overbroad in light of Chaplinsky).

124. See, e.g., Karlan v. City of Cincinnati, 416 U.S. 924 (1974); Rosen v. California, 416 U.S. 924 (1974); Kelly v. Ohio, 416 U.S. 923 (1974); Lucas v. Arkansas, 416 U.S. 919 (1974); Brown v. Oklahoma, 408 U.S. 914 (1972); Lewis v. New Orleans, 408 U.S. 913 (1972); Rosenfeld v. New Jersey, 408 U.S. 901 (1972). Professor Lawrence twice states that Cohen v. California, 403 U.S. 15 (1971), quoted approvingly Chaplinsky's language that certain words could be classified as unprotected fighting words per se, without regard to the circumstances in which they were uttered. See Lawrence, at 437 n.29, 453 n.92. But this citation does not support the continuing validity of that language, in light of the Court's subsequent rulings in Gooding and other fighting words cases.

125. See, e.g., Eaton v. City of Tulsa, 415 U.S. 697, 699 (1974) (per curiam) (reversing contempt of court conviction for witness' use of word "chickenshit," since there was no showing that it posed imminent threat to administration of justice); Hess v. Indiana, 414 U.S. 105, 109 (1973) (per curiam) (reversing disorderly conduct conviction where statement during antiwar demonstration-"We'll take the fucking strect later [or again]"-was not directed at any particular person or group and there was no showing that violence was imminent).

126. L. TRIBE, supra note $58, \S 12-18$, at $929 \&$ n.9. A strictly limited fighting words concept is consistent with the views of Zechariah Chafee, whose writings provided the definition of "fighting words" that the Court adopted in Chaplinsky v. New Hampshire, 315 U.S. 568, 572. See Z. ChAFEe, Free SPEech IN THE UNITED STATES 151-52 (1941). In the same book, shortly after the passage proposing this definition, Chafec qualified his account of fighting words: 
In accordance with its narrow construction of constitutionally permissible prohibitions upon "fighting words," the Court has overturned every single fighting words conviction that it has reviewed since Chaplin$s k y .{ }^{127}$ Moreover, in a subsequent decision, the Court overturued an injunction that had been based on the very word underlying the Chaplinsky conviction. ${ }^{228}$

For the foregoing reasons, Supreine Court Justices 129 and constitutional scholars persuasively inaintain that Chaplinsky's fighting words doctrine is no longer good law. ${ }^{130}$ More importantly, constitutional scholars have argued that this doctrine should no longer be good law, for

\footnotetext{
This breach of peace theory is peculiarly liable to abuse when applied against unpopular expressions and practices. It makes a man a criminal simply because his neighbors liave no self-control. ... Thus ... these crimes of injurious words must be kept within very narrow Id. limits if they are not to give excessive opportunities for outlawing heterodox ideas.
}

127. See supra notes $124-25$.

128. Compare Cafeteria Employees Local 302 v. Angelos, 320 U.S. 293, 295 (1943) (use of word "fascist" is "part of the conventional give-and-take in our economic and political controversies" and hence protected under federal labor law) with Chaplinsky, 315 U.S. at 573-74 (conviction affirmed on ground that words "God damned racketecr" and "damned Fascist," when addressed to police officer, were likely to provoke violent response). See also Note, First Amendment Limits on Tort Liability for Words Intended to Inflict Severe Emotional Distress, 85 CoLUM. L. REV. 1749 (1985). The autlior stated that:

The principle that the advocacy of ideas is subject to regulation when such advocacy is intended to and likely to incite immediate violence remains good law. The continued valid. ity of the application of this principle to the facts in Chaplinsky, lowever, is questionable because tlee addressee in Chaplinsky was a police officer. It is possible that the Court would now hold that because of his special training, the likelihood of a police officer responding violently is too remote for words addressed to a police officer to constitute "fighting" words.

Id. at 1768 n.98 (citations omitted). Accord Lewis v. City of New Orleans, 408 U.S. 913, 913 (1972) (Powell, J., concurring) (suggested that Court should apply separate standard when addressce of alleged fighting words is police officer).

129. Gooding v. Wilson, 405 U.S. 518, 537 (1972) (Blackmun, J., dissenting, joined by Burger, C.J.) ("[T]he Court, despite its protestations to the contrary, is merely paying lip service to Chaplinsky.").

130. See, eg., Gard, Fighting Words as Free Speech, 58 WasH. U.L.Q. 531,536 (1980) (postChaplinsky Supreme Court decisions have rendered fighting words doctrine "nothing more than a quaint remnant of an earlier morality that lias no place in a democratic society dedicated to the principle of free expression"); Shea, "Don't Bother to Smile When You Call Me That"-Fighting Words and the First Amendment, 63 KY. L.J. 1, 1-2 (1975) ("majority of the U.S. Supreme Court has gradually concluded that fighting words, no matter how narrowly defined, are a protected form of speech"). See also Letter from Professor Gerald Guntlier to Professor George Parker, Chair of the Student Conduct Legislative Council at Stanford University (May 1, 1989), reprinted in Stanford Univ. Campus Rep., May 3, 1989, at 18 [hereinafter Guntlıer letter (May 1, 1989)]. In his letter, Professor Gunther stated that:

[T]liere has been only one case in the history of the Supreme Court in which a majority of the Justices has ever found a statement to be a punishable resort to "fighting words." (That case was Chaplinsky v. New Hampshire, a nearly 50-year-old case involving words which would very likely not be found punisliable today.) More important, in the nearly half-century since Chaplinsky, there have been repeated appeals to the Court to recognize the applicability of the "fighting words" exception. ... . [I]n every one of the subsequent attempted reliances on that exception, the Supreme Court has refused to affirm the chal- 
reasons that are particularly weighty in the context of racist slurs. ${ }^{131}$ First, as Professor Gard concluded in a comprehensive review of both Supreme Court and lower court decisions that apply the fighting words doctrine, the asserted governmental interest in preventing a breach of the peace is not logically furthered by this doctrine. He explained that:

[I]t is fallacious to believe that personally abusive epithets, even if addressed face-to-face to the object of the speaker's criticism, are likely to arouse the ordinary law abiding person beyond mere anger to uncontrollable reflexive violence. Further, even if one unrealistieally assumes that reflexive violence will result, it is unlikely that the fighting words doctrine can successfully deter such lawless conduct. ${ }^{132}$

Second, just as the alleged peace-preserving purpose does not rationally justify the fighting words doctrine in general, that rationale also fails to justify the fightimg words doctrine when applied to racial slurs in particular. As Professor Kalven noted, "outbursts of violence are not the necessary consequence of such speech and, more important, such violence when it does occur is not the serious evil of the speech."133 Rather, as Professor Lawrence stresses, the serious evil of racial slurs consists of the ugliness of the ideas they express and the psychic injury they cause to their addressees. ${ }^{134}$ Therefore, the fighting words doctrine does not address and will not prevent the injuries caused by campus racist speech.

Even if there were a real danger that racist or other fighting words would cause reflexive violence, and even if that danger would be reduced by the threat of legal sanction, the fighting words doctrine still would be problematic in terms of free speech principles. As Professor Chafee observed, this doctrine "makes a man a criminal simply because his neighbors have no self-control and cannot refrain from violence." 135 In other contexts, the Court appropriately has refused to allow the addressees of speech to exercise such a "heckler's veto."136

\footnotetext{
lenged convictions. In short, one must wonder about the strength of an exception which, while theoretically recognized, has ever since 1942 not been found apt in practice.

131. See, e.g., Note, supra note 128, at 1757 n.44 (Chaplinsky may well reflect concerns peculiar to the decade when it was decided, rather than enduring first amendment principles).

132. See Gard, supra note 130 , at $\mathbf{5 8 0 .}$

133. H. Kalven, The Negro AND the First Amendment 14-15 (1965).

134. See Lawrence, at 457-76.

135. Z. ChAFEE, supra note 126 , at 151 .

136. See, e.g., Gregory v. City of Chicago, 394 U.S. 111 (1969) (holding that there was constitutionally insufficient evidence to support disorderly conduct convictions for civil rights demonstrators who failed to disperse upon police order; Court refused to consider evidence noted by Justice Black in dissent that hostile crowd of 1,000 spectators was growing unmanageable in spite of efforts of 100 uniformed police officers); Cox v. Louisiana, 379 U.S. 536, 550 (1965) (reversed civil rights demonstrators' breach of peace convictions, finding insufficient evidence to support local officials' claims that spectator violence was imminent, where there were 100 to 300 "muttering" spectators); Terminiello v. Chicago, 337 U.S. 1 (1949) (where race-baiting speaker attracted "angry and turbulent" crowd, Court reversed breach of peace conviction).
} 
The fighting words doctrine is constitutionally flawed for the additional reasons that it suppresses much protectible speech and that the protectible speech of minority group ineinbers is particularly vulnerable. Notwithstanding the Supreine Court's linitation of the doctrine's scope, Professor Gard's survey reveals that the lower courts apply it inuch more broadly. Since the Supreine Court only reviews a fraction of such cases, the doctrine's actual mipact on free speech must be assessed in terms of these speech-restrictive lower court rulings. Professor Gard concluded that, in the lower courts, the fighting words doctrine "is almost uniformly invoked in a selective and discriminatory inanner by law enforcement officials to punish trivial violations of a constitutionally impermissible interest in preventing criticism of official conduct." 137 Indeed, Professor Gard reported, "it is virtually impossible to find fighting words cases that do not involve either the expression of opinion on issues of public policy or words directed toward a government official, usually a police officer."138 Even inore disturbing is that the reported cases indicate that blacks are often prosecuted and convicted for the use of fighting words. ${ }^{139}$ Thus, the record of the actual implementation of the fighting words doctrine demonstrates that-as is the case with all speech restrictions-it endangers principles of equality as well as free speech. ${ }^{140}$ That record substantiates the risk that such a speech restriction will be applied discriminatorily and disproportionately against the very ininority group meinbers whoin it is intended to protect. ${ }^{141}$

137. Gard, supra note 130 , at 580 .

138. Id. at 548. Accord id. at 568. Compare Lawrence, at $437 \mathrm{n.29}$ ("[T]here is no evidence that the continued usage of [the fighting words doctrine] has led down the slippery slope to rampant censorship.").

139. See, e.g., Lewis v. City of New Orleans, 415 U.S. 130 (1974) (state court upheld conviction on basis of fighting words doctrine in situation in which police officer said to young suspect's mother, "[g]et your black ass in the goddamned car," and she responded, "you god damn mother fucking police-I am going to [the Superintendent of Police] about this."); Street v. New York, 394 U.S. 576 (1969) (black man who protested against shooting of civil rights leader James Meredith by burning Ameriean flag and saying, "If they let that happen to Meredith we don't need an American flag," was convicted under statute that criminalized words casting contempt on United States flag; Supreme Court rejected contention that conviction could be justified on fighting words rationale, $i d$. at 592); Edwards v. South Carolina, 372 U.S. 229, 236 (1963) (state court upheld convictions of civil rights demonstrators for holding placards stating "I am proud to be a Negro" and "Down with Segregation"; Supreme Court rejected contention that convictions could be justified on fighting words doctrine); Waller v. City of St. Petersburg, 245 So. 2d 685 (Fla. Dist. Ct. App. 1971), rev'd, City of St. Petersburg v. Waller, 261 So. 2d 151 (Fla. 1972) (black man was convicted for shouting "pig" at passing police car, and state supreme court upheld conviction based on fighting words doctrine).

140. See infra text accompanying notes $365-96$.

141. See Gard, supra note 130, at 566 ("Many commentators have reeognized that [the] problem of discriminatory enforcement is particularly acute in the fighting words context. [One very real] danger is . . . that the penal law will be selectively invoked against members of racial or other minority groups and speakers who espouse ideological views unpopular with enforcement officials.") 
Professor Lawrence himself notes that many Supreme Court decisions that overruled fighting words convictions involved a "potentially offended party [who] was in a position of relative power when compared with the speaker."142 As Professor Gard demonstrated, for each such conviction that was reviewed and overturned by the Supreme Court, many others were not. 143 Thus, Professor Lawrence and other proponents of Stanford's fighting words code must beheve that the officials who enforce that code will do so in a manner that differs from the general enforcement pattern of similar regulations. They must have faith that Stanford officials, as opposed to other officials, are unusually sensitive to free speech rights in general, and to the free speech rights of mimority group members and dissidents in particular.

Based on his analysis of the actual application of the fighting words doctrine, Professor Gard adheres to no such faith in the discretion of officials. In response to another legal academic's suggestion that the fighting words doctrine could be invoked to protect the aged and infirm from "the vilest personal verbal abuse," 144 Professor Gard said that this was "a romantic vision that exists only in the imagination of a law professor." 145 Even assuming that Stanford officials might be unusually attentive to free speech values when implementing the fighting words doctrine, Stanford's use of that doctrine could fuel an increased use by other officials, who might well fail to implement it in a speech-sensitive fashion. ${ }^{146}$

Because of the problems with the fighting words doctrine, the committee that proposed a hate speech policy for the University of Texas expressly declined to use it as a model. ${ }^{147}$ Likewise, recognizing the weakness of the public peace rationale, the proponents of the Stanford code have attempted to reinvigorate the other rationale that the Supreme Court enunciated in its Chaplinsky dictum, but has since abandonedthe notion that such words inflict psychic or emotional injury by their

(footnote omitted). See also id. at $\mathbf{5 7 1}$ (doctrine creates danger that the common meaning ascribed to words by certain subcultures will be punished based on "myopic ethnocentricity" of officials who enforce rules); Karst, Equality as a Central Principle in the First Amendment, 43 U. CHI. L. REv. 20, 38 (1975) ("[S]tatutes proscribing abusive words are applied to members of racial and political minorities more frequently than can be wholly explained by any special proclivity of those people to speak abusively.").

142. Lawrence, at 453 n.92.

143. See Gard, supra note 130 , at 564 .

144. Shea, supra note 130 , at 22.

145. Gard, supra note 130 , at 564 .

146. Professor Lawrence recognizes the potential danger that any spech-restricting precedent "would pose for the speech of all dissenters," and that such a dangerous precedent "might . . . include general societal tolcrance for the suppression of speech." Lawrence, at 458 \& n.106.

147. See University of Texas Report, supra note 115, at 16-20. 
very utterance. ${ }^{148}$ But this attempted "solution" to the problems flowing from the breach of the peace rationale causes another set of problems. First, the Supreme Court has never relied upon Chaplinsky's psychic harm dictum to sustain a fighting words conviction. ${ }^{149}$ Second, after it pronounced that dictum, the Court issued a line of decisions protecting speech that was allegedly offensive and that assertedly could have caused emotional or psychic injury. ${ }^{150}$ Consequently, as Professor Gard stated, to revive Chaplinsky's long-since discredited second rationale "would turn the constitutional clock back at least [fifty] years."151

\section{Intentional Infliction of Emotional Distress. A coinmittee re-} port that the University of Texas is currently considering recoinmends the common law tort of intentional infliction of emotional distress as a basis for regulating campus hate speech. ${ }^{152}$ This doctrinal approach has

148. See Stanford Code and Comments, supra note 24, at 3. The pertinent part of the Stanford Code and Comments states that:

The Supreme Court's phrase [in Chaplinsky] "insulting or 'fighting' words" is often shortened to simply "fighting words," an expression which ... may ... have certain misleading connotations. First, the expression may imply that violence is considered an acceptable response to discriminatory vilification.... Second, exclusive focus on the actual likelihood of violence might suggest that opponents of controversial speech can transform it into forbidden "fighting words" by plausibly thrcatening violent response to it. ... Finally, the "fighting words" terminology might be thought to imply that extreme forms of personal abuse become protected speech simply because the victims are, for example, such disciplined practitioners of non-violence ... that they do not ... pose an actual and imminent threat of violent retaliation. Such a limitation might be appropriate under a breach of peace statute, whose sole purpose is to prevent violence, but does not make sense in an antidiscrimination provision such as this one.

149. See Gard, supra note 130, at 577.

150. See, e.g., United States v. Eichman, 110 S. Ct. 2404, 2409 (1990) (prosecution for burning American flag in violation of Flag Protection Act of 1989, Pub. L. No. 101-131, 103 Stat. 777, held inconsistent with First Amendment protection of expressive conduct); Hustler Magazine v. Falwell, 485 U.S. 46 (1988) (first and fourtecnth amendments prohibit public figures from recovering damages for intentional infliction of emotional distress due to caricature publication without showing false statements of fact made with "actual malice"); Spence v. Washington, 418 U.S. 405 (1974) (conviction for hanging flag upside down with peace symbol taped on held invalid; statute held to be impermissible infringement on protected expression); Cohen v. California, 403 U.S. 15 (1971) (first and fourteenth amendments require state to show compelling reason to make public display of fourletter expletive a criminal offense); Strect v. New York, 394 U.S. 576 (1969); Terminiello v. City of Chicago, 337 U.S. 1 (1949) (Court reversed breach of peace conviction where race-baiting speaker attracted "angry and turbulent" crowd). See also infra text accoinpanying note 164 (quoting passage from Hustler referring to Court's "longstanding refusal to allow damages to be awarded because the speech in question may have an adverse emotional impact on the audience").

151. Gard, supra note 130, at 577.

152. See University of Texas Report, supra note 115, at 7 (defines prohibited "racial harassment" as "extreme or outrageous acts or communications that are intended to harass, intimidate, or humiliate a student or students on account of race, color, or national origin and that reasonably cause them to suffer severe emotional distress").

The Report's proposal includes the following limitations on the availability of the intentional infliction of emotional distress theory for barring speech: "racial harassment by communication usually will require repeated verbal conduct," $i d$; liability should be found "only where the conduct 
a logical appeal because it focuses on the type of harm potentially caused by racist speech that universities are most concerned with alleviatingnamely, emotional or psychological harm that interferes with studies. In contrast, the harm at which the fighting words doctrine aims-potential violence by the addressee against the speaker-is of less concern to most universities. ${ }^{153}$

Traditional civil libertarians caution that the intentional infliction of emotional distress theory should almost never apply to verbal harassment. ${ }^{154}$ A major problem with this approach is that,

the innate vagueness of the interest in preventing emotional injury to listeners suggests that any attempt at judicial enforcement will inevitably result in the imposition of judges' subjective linguistic preferences on society, discrimination against ethnic and racial minorities, and ultimately the misuse of the rationale to justify the censorship of the ideological content of the speaker's message. ${ }^{155}$

Again, as was true for the fighting words doctrime, there is a particular danger that this speech restrictive doctrine also will be enforced to the detriment of the very minority groups whom it is designed to protect.

The general problems with the intentional infliction of emotional distress theory counsel against application in the campus context specifi-

has been so outrageous in character, and so extreme in degree, as to go beyond all possible bounds of decency, and to be regarded as atrocious, and utterly intolerable in a civilized community," id. at 14 (quoting RESTATEMENT (SECOND) OF TORTS $\S 46$ comment d (1965)); "[t]he factual context is critical to the judgment as to what acts and words are extreme and outrageous," id.; the rule applies "only where the distress inflicted is so severe that no reasonable [person] could be expected to endure it," id. at 15 (quoting RESTATEMENT (SECOND) OF TORTS $\$ 46$ comment $j$ (1965)); and the rule would not apply to either "[a]bstract statements not addressed to particular listeners," $i d$. at 20 , or "the assertion of opinions," $i d$. at 21.

153. See, eg., id. at 19-20. The Report stated that:

[S]evere emotional distress may be present even where the victim is unlikely to respond with violence, and violence inay occur even where the emotional harm is slight.

... [Under] the "fighting words" approach. ... there is an incongruity between the real reason for the policy (avoidance of racially discriminatory humiliation and emotional distress) and the constitutional reason (avoidance of violence), the doctrinal box into which the draftsmen are attempting to make the real reason fit. It is much preferable for a racial harassment policy to focus on the rcal injury of severe emotional distress.

154. See F. Halman, supra note 59, at 152-56. According to Franklyn Haiman, the tort of intentional infliction of emotional distress endangers free speech: it involves "boundless subjectivity," id. at 152; subjects people to punishment because they violate "changing sensitivities" of particular community at particular time, id.; perpetuates stereotyping, invites "radically unpredictable" judicial decisionmaking, id. at 153; and incorrectly assumes that all inembers of racial or other groups have monolithic responses to challenged stimuli. Haiman recommends limiting such actions to knowingly false communication. See also Note, supra note 128, at 1749-50 (extreme and outrageous language should be object of tort liability only when such language constitutes fighting words or invades private arca such as home; even latter speech should not be basis for tort recovery by public official or public figure unless defendant made it impossible for such person to avert attention).

155. Gard, supra note 130 , at 578 (emphasis added). 
cally. ${ }^{156}$ Citing these reasons, Stanford University declined to base its hate speech regulation on this tort model. ${ }^{157}$ Moreover, even though the University of Texas committee report concluded that the emotional distress approach was less problematical than the fighting words approach, it cautioned: "[T]here can be no guarantee as to the constitutionality of any university rule bearing on racial harassment and sensitive nratters of freedom of expression."158

The position that the intentional infliction of emotional distress tort should virtually never apply to words recently received support in Hustler Magazine v. Falwell. ${ }^{159}$ Chief Justice Rehnquist, writing for a unanimous Court, reversed a jury verdict which had awarded damages to the nationally-known minister, Jerry Falwell, for the intentional infliction of emotional distress. The Court held that a public figure may not "recover damages for emotional harm caused by the publication of an ad parody offensive to him, and doubtless gross and repugnant in the eyes of most." 160 The Court further ruled that public figures and public officials may not recover for this tort unless they could show that the publication contains a false statement of fact which was made with "actual malice," i.e., with knowledge that the statement was false or with reckless disregard as to whether or not it was false. ${ }^{161}$ In other words, the Court required public officials or public figures who claim intentional infliction of

156. See Report of Workshop on Racist and Sexist Speech on College and University Campuses, Annenberg Washington Program of Northwestern University, Washington, D.C., at 3 (Apr. 12, 1990) [hereinafter Report of Annenberg Workshop] (available from author). The Report of the Annenberg Workshop stated that:

Most members of the group had difficulty with the subjectivity involved in making judg. ments on the basis of the emotional pain suffered by the targets of [hate speech]. No one denied that real pain is often suffered and no one was unconcerned about the possible personal consequences of such pain or its negative impact on equality of educational opportunity. But the prevailing view seemed to be that emotional pain, by itself, cannot be measured with the precision and objectivity required of any rule restricting speech.

157. See Stanford Code and Comments, supra note 24 , at 4 . The pertinent part of the Code and Comments stated that:

[T] he "emotional distress" rubric. .. . has drawbacks as the legal basis for a discriminatory harassment regulation. It is less well established in free speech law than is the fighting words concept. Further, taken as it is from tort law, it focuses primarily on the victim's reaction to abuse .... We think it better in defining a disciplinary offense to focus on the prohibited conduct; we prefer not to require the victims of personal vilification to display their psychic scars in order to establish that an offense has been committed.

Notwithstanding its recognition of the constitutional weaknesses of the emotional distress approach, Stanford adopted a rule that is modeled on the Chaplinsky dictum that also sought to protect against emotional distress. See supra notes 146-51 and accompanying text.

158. University of Texas Report, supra note 115, at 13.

159. 485 U.S. 46 (1988).

160. Id. at 50 .

161. Id. at 56. 
emotional distress to satisfy the same heavy burden of proof it imposes upon such individuals who bring defamation claims. ${ }^{162}$

Although the specific Falwell holding focused on public figure plaintiffs, much of the Court's language indicated that, because of first amendment concerns, it would strictly construe the intentional infliction of emotional distress tort in general, even when pursued by non-public plaimtiffs. For exainple, the Court said, to require a statement to be "outrageous" as a prerequisite for imposing hability did not sufficiently protect first amendment values. Because the "outrageousness" of the challenged statement is a typical element of the tort (it is included in the Restatement definition ${ }^{163}$ ) the Court's indication that it is constitutionally suspect has ramifications beyond the sphere of public figure actions. The Court warned:

"Outrageousness" in the area of political and social discourse has an inherent subjectiveness about it which would allow a jury to impose liability on the basis of the jurors' tastes or views, or perhaps on the basis of their dislike of a particular expression. An "outrageousness" standard thus runs afoul of our longstanding refusal to allow damages to be awarded because the speech in question may have an adverse emotional impact on the audience. ${ }^{164}$

For the reasons signalled by the unanimous Supreme Court in Falwell, any cause of action for intentional infliction of enotional distress that arises froin words inust be narrowly framed and strictly apphed in order to satisfy first amendinent dictates.

3. Group Defamation. Professor Lawrence does not elaborate on either the constitutionality or efficacy of the group defamation concept, yet he approvingly notes others' alleged support for it. ${ }^{165}$ The group defamation concept, however, has been thoroughly discredited by others. ${ }^{166}$

162. See New York Times v. Sullivan, 376 U.S. 254 (1964).

163. See RESTATEMENT (SECOND) OF TORTS $\S 46$ (1965).

164. Falwell, 485 U.S. at 55.

165. See Lawrence, at 464 n.124. But see Downs, Skokie Revisited: Hate Group Speech and the First Amendment, 60 Notre DAME L. REv. 629, 661-66 (1985) (argues that group defamation statutes are unconstitutional except for face-to-face harassment of individual or small group, similar to fighting words situation).

166. See, e.g., Beaularnais v. Illinois, 343 U.S. 250, 271 (1952) (Black, J., dissenting) (the sugarcoated label "group hibel law" does not make censorship less deadly); id. at 284 (Douglas, J., dissenting) (regulation of speecl must always meet clear and present danger test); see also id. at 277 (Reed, J., dissenting); id. at 287 (Jackson, J., dissenting); Tanenliaus, Group Libel, 35 CoRNELL L.Q. 261 (1950); Comment, Race Defamation and the First Amendment, 34 FordHAM L. REV. 653 (1966). It also is noteworthy that Professor Riesman, who wrote an influential series of articles advocating group defamation laws in 1942, subsequently changed his position. See Riesman, Democracy and Defamation: Fair Game and Fair Comment II, 42 ColuM. L. REv. 1282 (1942); Riesman, Democracy and Defamation; Fair Game and Fair Comment I, 42 Colum. L. REv. 1085 (1942); Riesman, 
First, group defamation regulations are unconstitutional in terms of both Supreme Court doctrine and free speech primciples. To be sure, the Supreme Court's only decision that expressly reviewed the issue, Beauharnais v. Illinois, ${ }^{167}$ upheld a group libel statute against a first amendment challenge. However, that 5-4 decision was issued almost forty years ago, at a relatively early point in the Court's developing free speech jurisprudence. Beauharnais is widely assumed no longer to be good law in hight of the Court's subsequent speech-protective decisions on related issues, notably its holdings that strictly limit individual defamation actions so as not to chill free speech. ${ }^{168}$

Statements that defame groups convey opinions or ideas on matters of public concern, 169 and therefore should be protected even if those statements also mjure reputations or feelings. ${ }^{170}$ The Supreme Court recently reaffirmed this principle in the context of an individual defamation action, in Milkovich v. Lorain Journal Co. ${ }^{171}$

Democracy and Defamation: Control of Group Libel, 42 CoLuM. L. REv. 727 (1942). But see S. WALKER, supra note 16, at 330 n.23, 437.

167. 343 U.S. 250 (1952).

168. See, e.g., Collin v. Smith, 578 F.2d 1197, 1205 (7th Cir.), cert. denied, 439 U.S. 916 (1978) (citing cases expressing "doubt, which we share, that Beauharnais remains good law at all after the constitutional libel cases"). See also L. TR1BE, supra note 58, § 12-17, at 926-27 (In partieular, New York Times Co. v. Sullivan, 376 U.S. 254 (1964), "seemed to some to eclipse Beauharnais' sensitivity to ... group defamation claims ... because New York Times required public officials bringing libel suits to prove that a defamatory statement was directed at the official personally, and not simply at a unit of government.").

169. The faet that statements that defame groups convey ideas concerning issues of public importance is illustrated by Beauhamais itself. The statements that were the basis for the defendant's conviction were set out on a petition addressed to city officials and seeking readers' signatures. See Beauhamais, 343 U.S. at 267, 276 (Black, J., dissenting).

170. See Letter from Professor William Cohen to Professor George Parker, chair of the Student Conduct Legislative Council of Stanford University (March 10, 1989), reprinted in Stanford Univ. Campus Rep., March 15, 1989, at 18 [hereinafter Cohen letter (March 10, 1989)]. In his letter, Professor Cohen stated that:

I have been asked why it is so important to draw a distinction between personal abusewhere I concede the possibility of regulation-and similar speech that is more generally distributed. If there is harm in being the target of an individual racial epithet, is not the harm the same, or greater, when the epithet is addressed to a broader audience? Indeed, it is. ... [H] owever, it is not appropriate to look only to one side of the balance. The problem is that there are larger interests in freedom of expression that loom when speech enters the public arena. These are interests that can not be rejected in the case of speech considered by the community to be erroneous, dangerous and harmful without limiting permissible expression to the trne and the relatively harmless.

171. 110 S. Ct. 2695 (1990). Although the Court declined "to ereate a wholesale defamation exemption for anything that might be labeled 'opinion,' " $i d$. at 2705 , it stressed that statements would only be actionable in defamation suits if a reasonable factinder could conclude that they "imply an assertion" of faet. Id. The Court also summarized the various existing doctrines limiting defamation actions which are designed to ensure that expressions of ideas or opinions would not be chilled:

Hepps ensures that a statement of opinion relating to matters of public concern which does not contain a provably false factual connotation will receive full constitutional proteetion. 
In addition to flouting constitutional doctrine and free speech principles, rules sanctioning group defanation are ineffective in curbing the specific class of hate speech that Professor Lawrence advocates restraining. Even Justice Frankfurter's opinion for the narrow Beauharnais majority repeatedly expressed doubt about the wisdom or efficacy of group libel laws. Justice Frankfurter stressed that the Court upheld the Illinois law in question only because of judicial deference to the state legislature's judgment about the law's effectiveness. ${ }^{172}$

The concept of defaination encoinpasses only false stateinents of fact that are made without a good faith behief in their truth. Therefore, any disparaging or insulting statement would be immune from this doctrine, unless it were factual in nature, deinonstrably false in content, and made in bad faith. Members of minority groups that are disparaged by an allegedly libelous stateinent would hardly have their reputations or psyches enhanced by a process in which the maker of the statement sought to prove his good faith belief in its truth, and they were required to demonstrate the absence thereof. ${ }^{173}$

Next, the Bresler-Letter Carriers-Falwell line of cases provide protection for statements that cannot "reasonably [be] interpreted as stating actual facts" about an individual (citation omitted). This provides assurance that public debate will not suffer for lack of... the "rhetorical hyperbole" which has traditionally added much to the discourse of our Nation.

The New York Times-Butts and Gertz culpability requirements further ensure that debate on public issues remains "uninhibited, robust, and wide-open." Thus, where a statement of "opinion" on a matter of public concern reasonably implies false and defamatory facts regarding. . . . a private figure on a matter of public concern, a plaintiff must show that the false connotations were made with some level of fault as required by Gertz. Finally, the enhanced appellate review required by Bose Corp., provides assurance that the foregoing determinations will be made in a manner so as not to "constitute a forbidden intrusion of the field of free expression."

Id. at 2706-07 (footnotes omitted).

172. See Beauharnais, 343 U.S. at 261-62. In Beauharnais, the Supreme Court stated that: "It may be argued, and weightily, that this legislation will not help matters; that tension and on occasion violence between racial and religious groups must be traced to causes more deeply embedded in our society than the rantings of modern Know-Nothings." Later in the opinion, the Supreme Court stated that: "[I]t bears repeating . . that our finding that the law is not constitutionally objectionable carries no inplication of approval of the wisdom of the legislation or of its efficacy. These questions may raise doubts in our minds as well as in others." Id. at 267.

173. See, e.g., Tanenhaus, supro note 166, at 299. In his article, Tanenhaus stated that:

The defendant in his effort to convince the jury that his grounds for belief were reasonable would be justified in introducing into evidence every piece of hate-literature he could find. The courtrooin would in effeet be tumed into a public forum for his views. Considering the countless tons of defamatory literature available, it is hard to think of anything that a jury might not be convinced was reasonably and honestly believed.

Professor Lawrence's recommendation that a group defamation cause of action contain "the equivalent of an actual malice requirement," Lawrence, at $463 \mathrm{n} .119$, would exacerbate the foregoing problems. See id. ("Discussions that attempt to explore an issue of public concern would be protected, but group defamations that intentionally vilify a group or individual for purposes of harassment or intimidation would receive no protection."). 
One additional problem with group defamation statutes as a model for rules sanctioning campus hate speech should be noted. As with the other speech-restrictive doctrines asserted to justify such rules, group defamation laws imtroduce the risk that the rules will be enforced at the expense of the very minority groups sought to be protected. The Illinois statute ${ }^{174}$ upheld in Beauharnais is illustrative. According to a leading article on group libel laws, during the 1940s, the Illinois statute was "a weapon for harassment of the Jehovah's Witnesses," who were then "a minority ... very much more in need of protection than most."175 Thus, a rule based on the group defamation theory provides no guarantee that it will not be used against minorities.

\section{Even a Narrow Regulation Could Have a Negative Symbolic Impact on Constitutional Values}

Taking into account the constraints imposed by free speech principles and doctrines potentially applicable to the regulation of campus hate speech, it might be possible-although difficult-to frame a sufficiently narrow rule to withstand a facial first amendment challenge. The federal judge who invalidated the University of Michigan's anti-hate speech regulation as overbroad and vague expressly noted this possibility. ${ }^{176}$ ACLU affiliates that have challenged particular campus hate speech restrictions have proposed alternative policies that might pass constitutional muster as a facial matter. ${ }^{177}$ However, it bears reemphasizing that,

174. The Illinois statute provided, in pertinent part: "It shall be unlawful . . . to . . . publish ... in any public place ... any ... publication [which] ... exposes citizens of any race, color, creed or religion to contempt, derision or obloquy." Ill. REV. STAT., ch. 38, para. 471 (1949).

175. Tanenhaus, supra note 166, at 279-80. See also Beauharnais, 343 U.S. at 274 (1952) (Black, J., dissenting) ("[T]he same kind of state law that makes Beauharnais a criminal for advocating segregation ... can be utilized to send people to jail ... for advocating equality and nonsegregation.").

176. See Doe v. University of Mich., 721 F. Supp. 852, 862 (E.D. Mich. 1989) ("Under certain circumstances racial and ethnic epithets, slurs, and insults might . . . constitutionally be prohibited [under the fighting words doctrine]. In addition, such speech may also be sufficient to state a claim for common law intentional infliction of emotional distress.").

177. For example, the lawsuit challenging the University of Connecticut's hate speech rule was settled pursuant to the parties' agreement about the wording of an alternative rule, which the Connecticut Civil Liberties Union deemed to comport with first amendment strictures. See Appendix to Judgment, Proposed Consent Decrec, Exhibit A, Wu v. University of Conn., No. Civ. H-89-649 PCD (D. Conn. Jan. 25, 1990) (prohibits face to face use of "flghting words," defined as "personally abusive epithets which, when directly addressed to any ordinary person are, in the context used and as a matter of common knowledge, inherently likely to provoke an immediate violent reaction, whether or not they actually do so"). See also Plaintiffs' Reply Brief in Support of Motion for Preliminary Injunction at 9 n.9, Doe, 721 F. Supp. at 852 (No. 89-CV-71683-DT) (filed by ACLU of Michigan; dated Aug. 24, 1989) (proposed alternative to successfully challenged rule; alternative would prohibit "any action direeted toward another student . . . with the specific intention of inflicting emotional distress ... or interfering with ... academic efforts. ... The ... expression of any 
as the University of Texas report stressed, "[T]here can be no guarantee as to the constitutionality of any university rule bearing on racial harassment and sensitive matters of freedom of expression." 178

Even assuming that a regulation could be crafted with sufficient precision to survive a facial constitutional challenge, several further problems would remain, which should give any university pause in evaluating whether to adopt such a rule. Although these inherent problems with any hate speech regulation are discussed in greater detail below, ${ }^{179}$ they are summarized here. First, because of the discretion entailed in enforcing any such rule, they involve an inevitable danger of arbitrary or discriminatory enforcement. ${ }^{180}$ Therefore, the rule's implementation would have to be monitored to ensure that it did not exceed the bounds of the regulations' terms or threaten content- and viewpoint-neutrality principles. ${ }^{181}$ The experience with the University of Michigan's rulethe only campus hate speech rule that has an enforcement recordgraphically illustrates this danger. ${ }^{182}$

Second, there is an inescapable risk that any hate speech regulation, no matter how narrowly drawn, will chill speech beyond its literal scope. Members of the university community may well err on the side of caution to avoid being charged with a violation. For example, there is evidence that the rule which the University of Wisconsin implemented in 1989 has had this effect, even though it has not yet been directly enforced. ${ }^{183} \mathrm{~A}$ third problem inherent in any campus hate speech policy, as Professor Lawrence concedes, ${ }^{184}$ is that such rules constitute a precedent that can be used to restrict other types of speech. As the Supreme Court

idea in any form, unaccompanied by any action ... directed toward another student ... shall not be violative."). See also supra note 11 (policies adopted by ACLU California affiliates do not oppose regulation of narrowly defined campus hate speech). See also infra note 353 and accompanying tcxt.

178. University of Texas Report, supra note 115, at 13.

179. See infra text accompanying notes 227-74.

180. See Amsterdam, Perspectives on the Fourth Amendment, 58 MinN. L. Rev. 349, 435 (1974) ("The dangers of abuse of a particular power are, certainly, a pertinent consideration in determining whether the power should be allowed in the first instance.").

181. See L. TRIBE, supra note 58, $\S 12-10$, at 856 (Although the Constitution probably permits legislation punishing words that cause hurt by their mere utterance, such legislation "would be constitutionally problematic-the potential for content-specific regulation is always great.").

182. See infra text accompanying notes 203-25.

183. See Gribble, supra note 17. In his article, Gribble stated that:

Ron Novy, editor of the UWM Post [the student newspaper at the University of Wisconsin-Milwaukee], said he had the feeling that since the rule was put into effect, students had become less willing to speak frankly. said.

"Our letters to the editor are not quite as vehement as they've been in the past," he Novy said the rule had not "consciously" affected how the Post's writers approached
stories, "but it's in the back of your mind."

Id. at 8B, col. 1.

184. See Lawrence, at 458 n.106. 
has recognized, the long-range precedential impact of any challenged governmental action should be a factor in evaluating its lawfulness. ${ }^{185}$

Further, in light of constitutional constraints, any campus hate speech policy inevitably would apply to only a tiny fraction of all racist expression, and accordingly it would have only a symbolic impact. ${ }^{186}$ Therefore, in deciding whether to adopt such a rule, universities must ask whether that symbolic impact is, on balance, positive or negative in terms of constitutional values. ${ }^{187}$ On the one hand, some advocates of hate speech regulations maintain that the regnlations might play a valuable symbolic role in reaffirming our societal commitment to racial equality ${ }^{188}$ (although this is debatable). ${ }^{189}$ On the other hand, we inust beware of even a syınbolic or perceived diminution of our impartial commitment to free speech. Even a limitation that has a direct impact upon only a discrete category of speech may have a much more pervasive indirect impact-by undermining the first amendınent's inoral legitimacy. ${ }^{190}$

185. See, e.g., West Virginia State Bd. of Educ. v. Barnette, 319 U.S. 624, 641 (1943) ("It seems trite but necessary to say that the First Amendment ... was designed to avoid these [totalitarian] ends by avoiding these beginnings."); Boyd v. United States, 116 U.S. 616, 635 (1886) ("[I]llegitimate and unconstitutional practices get their first footing by slight . . . deviations from legal modes of procedure. This can only be obviated by adhering to the rule that constitutional provisions ... should be liberally construed.").

186. See infra Part II.

187. See Guntler letter (May 1, 1989), supra note 130. In his letter, Gunther stated that:

[Y]our entire enterprise- the recurrent effort to identify forbidden speech, now more narrowly defined - does not strike me as a significant part of a campus wide effort to eliminate discrimination and perhaps stems more from an interest in symbolic gestures rather than in concretely effective ones. This proposed symbolic vietory inevitably casts some pall over the vigor of campus speech and beyond that may well set an unfortunate precedent for future institutional action curbing speech even more severely.

188. See Letter from Professor William Cohen to Professor George Parker, chair of the Student Conduct Legislative Council of Stanford University (May 1, 1989), reprinted in Stanford Univ. Campus Rep., May 3, 1989, at 18 [hereinafter Cohen letter (May 1, 1989)]. Cohen wrote that: "While no one pretends that silencing racist remarks cures racism, there might be substantial symbolic cost in giving up on a legislative solution to this problem after so much effort. A number of the affected groups would reasonably see abandonment as demonstrating lack of institutional concern." See also University of Texas Report, supra note 115, at 1 (quoting charge of President William H. Cunningham of University of Texas at Austin to President's Ad Hoc Committee on Racial Harassment). President Cunningham stated that: "[O]ne of the primary reasons for adopting racial harassment policies is to affirm symbolically The University's commitment to tolerance and nondiscriminationeven if the rules themselves cannot completely eliminate the problem." Accord Matsuda, supra note 13 , at 2322 ("A legal response to racist speech is a statement that victims of racism are valued members of our polity.").

189. See Report of Annenberg Workshop, supra note 156, at 2. The Annenberg Report stated that: "The adoption of restrictions on derogatory speech. ... may . . give some symbolic support and reassurance to the victims of such communication. It is, however, ... of dubious effectiveness, even symbolically, in improving intergroup relationships. Indeed, sucl a response may lead to a backlash or a perception of official heavy-handedness."

190. Professor Walter Dellinger tellingly made this point about another proposed exeeption to the first amendment of an ostensibly limited nature-for physical desecration of the U.S. flag: 
Recently, the Supreme Court ringingly reaffirmed the core principle that a neutral commitment to free speech should trump competing symbolic concerns. In United States v. Eichman, which invalidated the Flag Protection Act of 1989, the Court declared:

Government may create national symbols, promote them, and encourage their respectful treatment. But the Flag Protection Act goes well beyond this by crimmally proscribing expressive conduct because of its likely communicative impact.

We are aware that desecration of the flag is deeply offensive to many. But the same might be said, for example, of virulent ethnic and religious epithets, vulgar repudiations of the draft, and scurrilous caricatures. "If there is a bedrock principle underlying the First Amendment, it is that the Government may not prohibit the expression of an idea simply because society finds the idea itself offensive or disagreeable." Punishing desecration of the flag dilutes the very freedom that makes this emblem so revered, and worth revering. ${ }^{191}$

\section{Professor LaWrence's Conception of Regulable Racist Speech Endangers Free Speech Principles}

The preceding discussion of relevant constitutional doctrine points to several problems with the Stanford regulations, as well as other regulations adopted or advocated by other universities. As previously explained, ${ }^{192}$ the Stanford regulations violate the cardinal principles that speech restrictions must be content- and viewpoint-neutral. Moreover, although these regulations purportedly incorporate the fighting words doctrine, ${ }^{193}$ they in fact go well beyond the narrow bounds that the Court has imposed on that doctrine, and, as the University of Michigan example demonstrates, they threaten to chill protected speech.

What would this proposed act of constitutional revision do to the moral legitimacy of the stance our Constitution has taken (and will continue to take) in defense of expression that offends many Americans as deeply as flag burning offends the great majority of us? . . . Once we have quickly passed the Twenty-seventh amendment to protect the sensibilities of those who revere the flag, what do we say to those who are particularly offended by, but must continue to tolerate, the burning of crosses by hooded members of the Ku Klux Klan, a brazen reminder of the era of lynching and terror? And what do we say to those who find themselves silenced and marginalized by sexualized (but not constitutionally "obscene") portrayals of women? What enduring Constitutional principle will remain unimpaired that will legitimately surmount these claims ....?

Hearings on Measures to Protect the Physical Integrity of the American Flag, Before the Senate Committee on the Judiciary, 101st Cong., Ist Sess. 553 (1989) (statement of Walter Dellinger).

191. United States v. Eichman, 110 S. Ct. 2404, 2409-10 (1990) (footnote omitted).

192. See supra text accompanying notes 104-12.

193. See Stanford Code and Comment, supra note 24 , at 1 . 


\section{A. The Proposed Regulations Would Not Pass Constitutional Muster ${ }^{194}$}

\section{The Regulations Exceed the Bounds of the Fighting Words Doc-} trine. As discussed above, ${ }^{195}$ the fighting words doctrine is fraught with constitutional problems. As a result, it either has been abrogated $s u b$ silentio or probably should be. In any event, even assuming that the doctrine is still good law, it has been severely circumscribed by Supreme Court rulimgs. Because those limits are necessitated by free speech principles, they must be strictly enforced. Professor Gard's thorough study of the law in this area summarizes the Court's limitations on the fighting words doctrine:

The offending language (1) must constitute a personally abusive epithet, (2) must be addressed in a face-to-face manner, (3) must be directed to a specific individual and be descriptive of that individual, and (4) must be uttered under such circumstances that the words have a direct tendency to cause an immediate violent response by the average recipient. If any of these four elements is absent, the doctrine may not justifiably be invoked as a rationale for the suppression of the expression. ${ }^{196}$

The operative language of the Stanford code provides:

Speech or other expression constitutes harassment by personal vilification if it:

a) is intended to insult or stigmatize an individual or a small number of individuals on the basis of their sex, race, color, handicap, religion, sexual orientation, or national and ethnic origin; and

b) is addressed directly to the individual or individuals whom it insults or stigmatizes; and

c) makes use of insulting or "fighting" words or non-verbal symbols.

In the context of discriminatory harassment by personal vilification, insulting or "fighting" words or non-verbal symbols are those "which by their very utterance infiict injury or tend to incite to an immediate breach of the peace," and which are commonly understood to convey direct and visceral hatred or contempt for human beings on the basis of their sex, race, color, handicap, religion, sexual orientation, or national and ethnic origin. ${ }^{197}$

A comparison of the Stanford code to the Supreme Court's four criteria for constitutional fighting words restrictions reveals that the code clearly does not satisfy one of the Court's criteria, and it may not satisfy the other three. Most importantly, as outlined above, since Gooding v.

194. As a private institution, Stanford University is not directly bound by first amendment standards. However, many private academic institutions make policy choices to adhere to standards that are consistent with their notions of academic freedom.

195. See supra text accompanying notes $116-51$.

196. Gard, supra note 130, at 563-64.

197. Stanford Code and Comments, supra note 24. 
Wilson the Court consistently has invalidated fighting words definitions that refer only to the content of words. Instead, it has insisted that these words niust be evaluated contextually, to assess whether they are likely to cause an iniminent breach of the peace under the circumstances in which they are uttered. Yet, the Stanford code punishes words which are comnionly understood to convey" group-based hatred. ${ }^{198}$ By proscribing certain words, without considering their context, the Stanford code violates Gard's fourth criterion, and for that reason alone falls afoul of the first aniendnient.

The Stanford code also may fail to satisfy the Court's strict paranieters for the fighting words doctrine in other respects. First, it does not expressly require that the prohibited speech "must constitute a personally abusive epithet," the first criterion in Professor Gard's list. Based on his analysis of cases that address the fighting words doctrine, Professor Gard concluded that "the utterance must constitute an extremely provocative personal insult" 199 in order to coniport with free speech principles. ${ }^{200}$

Although the Stanford code niay coniply with the Court's second and third requirenients, by prescribing that the prohibited speech be "addressed directly to the individual or individuals whon it insults or stigmatizes," both of these elenients have been construed so strictly that they niay not be satisfied by this provision. Son1e judicial rulings indicate that the second requirenient, the face-to-face elenient, "is not satisfied by nere technical physical presence, but contemplates an extremely close physical proximity." 201 The third requirement has been interpreted to mean that "the offensive words nust be descriptive of a particular person and addressed to that person." 202 The Stanford code does not require that the prohibited words describe the individual to whon they are addressed. Instead, under the Stanford code, the words may convey hatred for broad groups of people.

198. Id. (emphasis added). Compare the University of Connecticut's rule, supra note 177 (defining fighting words as those "which ... are, in the context used ... inherently likely to provoke an immediate violent reaction") (emphasis added).

199. Gard, supra note 130 , at 536.

200. See also id. at 541 ("The importance of the content-focused personally abusive epithet element cannot be overestimated. ... In essence it guarantees that the expression of ideas, no matter how offensive or distasteful, will be afforded constitutional protection.").

201. Id. at 559 (citing In re S.L.J., 263 N.W.2d 412, 420 (Minn. 1978)) (when alleged fighting words were spoken "from more than fifteen feet away rather than eye-to-eye, there was no reasonable likelihood that they would tend to incite an immediate breach of the peace"); Garvey v. State, 537 S.W.2d 709, 710 (Tenn. Crim. App. 1975) (face-to-face requirement was not met when defendant, while driving past police station, shouted "sooey" at police officer).

202. Gard, supra note 130 , at 561 (emphasis added). 
2. The Regulations Will Chill Protected Speech. Beyond its facial problems of violating neutrality principles and fighting words limitations, the Stanford code also will dampen academic discourse. This inevitable outcome is mdicated by the experience under the University of Michigan hate speech regulation. ${ }^{203}$

203. That regulation provided that, in certain "[e]ducational and academic centers," individuals were subject to discipline for:

Any behavior, verbal or physical, that stigmatizes or victimizes an individual on the basis of race, ethnicity, religion, sex, sexual orientation, creed, national origin, ancestry, age, marital status, handicap or Vietnam-era veteran status, and that ... [i]nvolves an express or implied threat to ... or has the purpose or reasonably foreseeable effect of interfering with an individual's academic efforts, employment, participation in University sponsored extra-curricular activities or personal safety ....

Doe v. University of Mich., 721 F. Supp. 852, 856 (E.D. Mich. 1989) (quoting The University of Michigan Policy on Discriminatory Harrassment (adopted April 14, 1988)). As originally adopted and implemented, the regulation also sanctioned speech that "[c]rcates an intimidating, hostile, or demeanimg environment for educational pursuits, employment or participation in University sponsored extra-curricular activities." Id. After the regulation was legally challenged, however, the University announeed that it was withdrawing that section on the grounds that "a need exists for further explanation and clarification" of it. Id. (quoting University of Michigan Public Announcement, August 22, 1989).

The Michigan rule was in effect for more than a year, and documents concerning its enforcement were produced during the litigation that ultimately led to its invalidation on first amendment grounds.

Professor Lawrence contends that it is unfair to judge the Stanford code in light of the experience under the Michigan rule, arguing that the latter was "clearly overbroad," and asserting that "it is difficult to believe that anyone at the University of Michigan Law School was consulted in drafting" it. Lawrence, at 477 n.161 \& 478 n.162.

It is ironic that, in this particular context, Professor Lawrence secks to focus the debate solely on the Stanford code. As previously observed, see supra note 27, throughout his article, he repeatedly defends alternative hate speech regulations that are not only broader than Stanford's but also broader than Michigan's. Moreover, his proffered rationales would justify sweeping prohibitions. See infra Part III. Therefore, perhaps Professor Lawrence should not be so quick to protest that the Michigan code was "obviously overbroad." Lawrence, at 478 n.162.

In any event, the record documents that the University did consult with law school faculty members, as well as university counsel and other lawyers. The University also received comments from numerous other individuals and groups, including the ACLU, in its drafting process. See Letter from Henry W. Saad (counsel to University in Doe litigation) to Honorable Avern Cohn, at 2 (Aug. 17, 1989) [hereinafter Saad letter] (available from author). Saad wrote that:

[University of Michigan] President Fleming also consulted with internationally recognized constitutional scholar and Dean of The University of Michigan Law School, Lee Bollinger, and internationally recognized labor/civil rights expert and former Dean of the University of Michigan Law School, Thcodore St. Antoine, regarding drafting of the Policy and reviewed the final draft with them.

See also Grano, supra note 8, at 9 ("President Fleming [said] that the university's lawyers and three of his colleagues from the law school, including First Amendment expert Dean Lee Bollinger, believed the proposed approach to be sound." Although the University believed the approach to be constitutional, "various individuals and organizations, including the American Civil Liberties Union, voiced objections on constitutional grounds to the provisions regulating speech.") Id. The Michigan ACLU affiliate "supported the concept [of regulating verbal harassment] with suggestions for improvement." See Regents of the University of Michigan, Minutes of March 1988 Meeting, at 19 (March 17, 1988) [hereinafter Michigan Regents' Minutes] (available from author). Therefore, Professor Lawrence's unsubstantiated assertion that the ACLU and "[t]raditional civil liberties law- 
Even though the Michigan regulation was in some respects broader than its Stanford counterpart, ${ }^{204}$ the latter rule also suffers from facial overbreadth and ambiguity. ${ }^{205}$ One of the key terms in the Stanford regulation, the term "stigmatize," also was contained in the Michigan regulation and specifically was ruled unconstitutionally vague. ${ }^{206}$ Accordingly, the Stanford code appears to be as constitutionally suspect as the Michigan rule, contrary to Professor Lawrence's assumption. As discussed in the preceding section, all the alternative theories that have been offered-the fighting words doctrine, the intentional infliction of emotional distress tort, and group defamation-also pose signiffcant threats to free speech principles. ${ }^{207}$

In Doe v. University of Michigan, ${ }^{208}$ the United States District Court for the Eastern District of Michigan held that the University of Michigan's anti-hate speech pohicy violated the first amendment because, as applied, it was overbroad ${ }^{209}$ and impermissibly vague. ${ }^{210}$ The court con-

yers typically have elected to stand by" while universities draft clearly unconstitutional rules, Lawrence, at 477 , is directly belied by the Michigan experience. For further refutation of this undocumented generalization, see infra notes 353-55 and accompanying text.

Following the Doe ruling, the University of Michigan did not, as Professor Lawrence suggests, "say to the black students, 'We tried to help you but the courts just won't let us do it.' " Lawrence, at $477 \mathrm{n} .161$. Rather, promptly after the Doe decision, the University adopted an interim policy that was more sensitive to frec speech concerns; the new policy has not been challenged by the ACLU or any other party. See Policy Statement: The University of Michigan Interim Policy on Discrimination and Discriminatory Conduct by Students in the University Environment (available from author). See also supra note 177 (during Doe litigation, ACLU suggested alternative policy language that might withstand constitutional scrutiny). More importantly, the University is working on a comprehensive educational program to deal with racist attitudes and to instill in students a multicultural perspective. Telephone interview with Elsa Cole, General Counsel, University of Michigan (August 22, 1990).

204. See supra note 61 .

205. See supra text accompanying notes 195-202. See also Cohen letter (May 1, 1989), supra note 188. Cohen wrote that: "Given the ambiguities-ambiguities I believe to be inevitable-the question arises whether the proposed rule, even with amendments, will chill dialogue as speakers try to avoid the danger zone."

206. See Doe, 721 F. Supp. at 867. Another term that is central to the Stanford code, "harassment," see supra text accompanying note 197, also has been held to be unconstitutionally vague. See Dorman v. Satti, 862 F.2d 432, 433, 436 (2d Cir. 1988) (in invalidating statute that prohibited "harass[ment] of persons "engaged in the lawful taking of wildlife," court noted that "harass" "can mean anything").

207. See supra text accompanying notes 116-75.

208. 721 F. Supp. 852 (E.D. Mich. 1989).

209. See City of Houston v. Hill, 482 U.S. 451, 458 (1987) (regulation of speech will be unconstitutionally overbroad if it "reaches a substantial amount of constitutionally protected conduct") (citing Hoffman Estates v. The Flipside, Hoffman Estates, Inc., 455 U.S. 489, 494 (1982)).

210. In particular, the term "stigmatize," also used in the Stanford code, specifically was held to be unconstitutionally vague. Doe, $721 \mathrm{~F}$. Supp. at 867.

The void-for-vagueness doctrine is enforced especially strictly in the first amendment context. See Kolender v. Lawson, 461 U.S. 352, 358 (1983); Hoffman Estates, 455 U.S. at 499; Smith v. Goguen, 415 U.S. 566, 573 (1974); Grayned v. City of Rockford, 408 U.S. 104, 109 (1972). 
cluded that during the year when the policy was in effect, the University "consistently applied" it "to reach protected speech."211 Moreover, because of the policy's vagueness, the court concluded that it did not give adequate notice of which particular expressions would be prohibited and which protected. ${ }^{212}$ Consequently, the policy deterred members of the umiversity commumity from engaging in protected expression for fear it might be sanctioned. This "chillimg effect" of any hate speech regulation is particularly problematic in the academic environment, given the special importance of a free and robust exchange of ideas. ${ }^{213}$

Moreover, the judge who ultimately found the Michigan rule unconstitutional did not share Professor Lawrence's opinion that it was "poorly drafted and obviously overbroad."214 To the contrary, his opinion expressly noted that he would not have found the rule unconstitutionally overbroad merely based on its language. Rather, he found it unconstitutional in light of the enforcement record. ${ }^{215}$ These findings prove the relevance of the Michigan case not only to the Stanford situation, but also to all other campus hate speech regulations. Regardless of how carefully these rules are drafted, they mevitably are vague and unavoidably invest officials with substantial discretion in the enforcement process; thus, such regulations exert a chilling effect on speech beyond their literal bounds.

In the recent wave of college crackdowns on racist and other forms of hate speech, examples abound of attempts to censor speech conveying ideas that clearly play a legitimate role in academic discourse, although some of us might find them wrongheaded or even odious. For example, the University of Michigan's anti-hate speech policy could justify attacks on author Salman Rushdie because his book, The Satanic Verses, ${ }^{216}$ was offensive to Muslims. ${ }^{217}$

211. See Doe, $721 \mathrm{~F}$. Supp. at 865 . The court cited the following examples of protected speech which had been subjected to the policy: a statement by a graduate student in the School of Social Work, in a research class, expressing his belief that homosexuality was a disease and that he intended to develop a counseling plan for changing gay clients to straight, $i d$; the reading of an allegedly homophobic limerick, which ridiculed a well-known athlete for his presumed sexual orientation, by a student in the School of Business Administration during a class public-speaking exercise, id.; and a statement by a student during an orientation session of a preclinical dentistry class, widely regarded as especially difficult, that he had heard that minorities had a hard time in the course and that they were not treated fairly, id. at 865-66.

212. See id. at 867.

213. See supra note 88.

214. Lawrence, at 478 n.162.

215. See Id.

216. S. Rushdie, The Satanic Verses (1988).

217. See Statement of the Washtenaw County Branch, American Civil Liberties Union, on the University of Michigan Policy "Discrimination and Discriminatory Harassment by Students in the University Environment" 6 (May 25, 1989). 
Such incidents are not aberrational. Any anti-hate speech rule inescapably entails some vagueness, due to the inherent imprecision of key words and concepts common to all such proposed rules. For example, most regulations employ one or more of the following terms: "demeaning," "disparaging," "harassing," "hostile," "insulting," "intimidating," and "stigmatizing." 218 Therefore, there is real danger that even a narrowly crafted rule will deter some expression that should be protected 219 -especially in the university environment. 220 In particular, such a rule probably will "add to the silence" on "gut issues" about racism, sexism, and other forms of bias that already impede interracial and other intergroup dialogues. ${ }^{221}$

Other examples of academic discourse that have been labeled censurable as hate speech include the following: a group of students complained that a faculty member had created a hostile atmosphere by quoting racist comments originally made at the turn of the century, even though the professor said that was not his intention, see id. at 4; another group of students contended that the former students' complaint about the professor had itself created a hostile atmosphere, see id. at 5; a law student suggested that judicial decisions reflecting adverse stereotypes about blacks should not be studied in law school courses, see Shaw, Caveat Emptor, N.Y.L. Sch. Rep., Apr. 1989, at 3; a Jewish professor was penalized for suggesting to his black students that they should celebrate the anniversary of their ancestors' liberation from slavery under the thirteenth amendment, just as Jews celebrate their ancestors' liberation from slavery during Passover, see Hentoff, Campus Court-Martial, Wash. Post, Dec. 15, 1988, at A25, col. 2; students complained about a professor's statement that black students are not sufficiently critical of human rights violations by black African governments, see McKinlcy, Minority Students Walk Out Over a Teacher's Remarks, N.Y. Times, Oct. 4, 1989, at B3, col. 5.

218. See Doe v. University of Mich., 721 F. Supp. 852, 867 (E.D. Mich. 1989) (holding unduly vague the terms "stigmatize," "victimize," " "threat' to an individual's academic efforts," and "interfering with an individual's acadcmic efforts"). Although Professor Lawrence protests that the Michigan regulation was "clearly overbroad," Lawrence, at 478 n.162, and hence cannot fairly be compared to the Stanford code, a key term in the latter is "stigmatize," which the Doe court held to be unconstitutionally vague. See supra text accompanying note 210. See also supra note 206 (citing decision holding the term "harass" to be unconstitutionally vague).

219. Regarding the chilling effect of a University of Connecticut anti-hate-speech mle utilizing some of these terms, see Brief of Amicus Curiae in Support of Plaintiff's Motion for Preliminary Injunction at 9-10 \& n.10, Wu v. University of Conn., No. Civ. H-89-649 PCD (D. Conn. Jan. 25, 1990) (submitted by ACLU). In its brief, the ACLU stated that:

Given [the mle's] ambiguities, a ... student could plausibly fear prosecution for voicing an opinion that members of the Unification Church ... are "cultists"; that Zionists are "imperialists" or that Palestinians are "terrorists"; that evangelical ministers are "hustlers" and their followers are "dupes"; or that homosexuals are "sick." Most ironically of all, a homosexual rights activist could perhaps be prosecuted for declaring that Catholics are "bigots" if they follow their Church's teaching that homosexuality is a sin . . . . Similarly, a black activist student leader might reasonably hesitate to characterize other black students, who are deemed insufficiently supportive of black causes, as "Uncle Toms" . . . .

220. See Cohen Letter (May 1, 1989), supra note 188.

221. Id. See also Letter from Pierre Bierre, research computer scientist in the Neuropsychology Laboratory of the departments of Psychiatry and Psychology, to George Parker, Chair of the Student Conduct Legislative Council, Stanford University (Mar. 16, 1989), reprinted in Stanford Univ. Campus Rep., Mar. 22, 1989, at 20 ("As any conflict counselor knows, the first step to resolve conflicts is to get people to open up and share unedited gut feelings, however irrational they may 
Additionally, it must be recognized that silencing certain expressions may be tantamount to silencing certain ideas. ${ }^{222}$ As the plaintiff in Doe v. Michigan argned:

[T] he policy ... is an official statement that at the University of Michigan, some arguments will no longer be tolerated. Rather than encourage her maturing students to question each other's beliefs on such diverse and controversial issues as the proper role of women in society, the merits of particular religions, or the moral propriety of homosexuality, the University has decided that it must protect its students from what it considers to be "unenlightened" ideas. In so doing, the University has established a secular orthodoxy by implying, among other things, that homosexuality is morally acceptable, [and] that ... feminism [is] superior to the traditional view of women $\ldots . .223$

The Michigan plaintiff was victimized directly by the "pall of orthodoxy"224 that the University's anti-hate speech policy cast over the campus. As a graduate student specializing in behavioral psychology, he felt that the rule deterred him froin classroom discussion of theories that some psychological differences ainong racial groups and between the sexes are related to biological differences, for fear of being charged with racial or sexual harassment.225

In addition to their chilling effect on the ideas and expressions of university commumity members, policies that bar hate speech could engender broader forms of censorship. As noted by Professor William Cohen of Stanford Law School, an anti-hate speech rule such as the one adopted by his university "purports to create a personal right to be free froin involuntary exposure to any form of expression that gives certain kinds of offense." Therefore, he explains, such a rule "could become a sword to challenge assigned readings in courses, the showing of films on campus, or the message of certain speakers."226

seem, and the second step is to remove the listening 'blocks' that prevent the other side from hearing those feelings.").

222. As Justice Harlan observed in Cohen v. California, 403 U.S. 15, 26 (1971), "[w]e cannot indulge in the facile assumption that one can forbid a particular word without also running the substantial risk of suppressing ideas in the process."

223. Affidavit of John Doe in Support of Plaintiff's Motion for Preliminary Injunction at para. 14, Doe v. University of Mich., 721 F. Supp. 852 (E.D. Mich. 1989) (No. 89-71683) [hereinafter Doc Affidavit].

224. Keyishian v. Board of Regents, 385 U.S. 589, 603 (1967). See also West Virginia State Bd. of Educ. v. Barnette, 319 U.S. 624, 642 (1943), which declared that:

If there is any fixed star in our constitutional constellation, it is that no official, high or petty, can prescribe what shall be orthodox in politics, nationalism, religion or other matters of opinion or force citizens to confess by word or act their faith therein. If there are any circuinstances which permit an exception, they do not now occur to us.

225. See Doe Affidavit, supra note 223, at paras. 7-11.

226. Cohen letter (March 10, 1989), supra note 170. Professor Cohen cited the following examples of potential censorship under this construction: a challenge by evangelical Christians to the film The Last Temptation of Christ (Barbara De Fina, released by Universal and Cineplex Odeon Films 


\section{B. The Proposed Regulations Would Endanger Fundamental Free Speech Principles}

The various proposed campus hate speech regulations, including the Stanford code that Professor Lawrence endorses, are inconsistent with current Supreme Court doctrine prescribing permissible limits on speech. More importantly, they jeopardize basic free speech principles. Whereas certain conduct may be regulable, speech that advocates such conduct is not, and speech inay not be regulated on the basis of its content, even if many of us strongly disagree with-or are repelled by-that content.

1. Protection of Speech Advocating Regulable Conduct. Civil libertarians, scholars, and judges consistently have distinguished between speech advocating unlawful conduct and the unlawful conduct itself. 227 Although this distinction has been drawn in numerous different factual settings, the fundamental underlying issues always are the same. For example, within recent years, some pro-choice activists have urged civil libertarians and courts to inake an exception to free speech principles in order to restrain the expressive conduct of anti-abortion activists. Instead, civil libertarians have persuaded courts to prohibit assaults, blockages of clinic entrances, trespasses, and other illegal conduct by antichoice activists. 228 Similarly, civil libertarians and courts ${ }^{229}$ have rejected pleas by some feminists to censor pornography that reflects sexist attitudes. ${ }^{230}$ Instead, civil libertarians have renewed their efforts to per-

1988); a challenge by blacks to D.W. Griffith's film The Birth of a Nation (Epoch Producing Corporation 1915); or a speech by Professor Shockley on racial differences.

227. See Brandenburg v. Ohio, 395 U.S. 444, 456-57 (1969) (Douglas, J., concurring) ("The line between what is permissible and not subject to control and what may be ... subject to regulation is the line between ideas and overt acts."); see also A. NEIER, supra note 63, at 74 (ACLU did not represent American Nazis and Nazi sympathizers prosecuted under Smith Act during World War II, because defendants appeared to be enemy agents who had committed overt acts helpful to Germany).

228. Compare S. WALKER, supra note 16, at 349 (discussing ACLU representation of anti-abortion demonstrators) with National Abortion Fed'n v. Operation Reseue, No. CV 89-1181 AWT (C.D. Cal. Aug. 29, 1989) (holding anti-abortion demonstrators in contempt for violating order previously obtained by Southern California ACLU to protect abortion clinics and patients from assaults and other illegal conduct).

229. In American Booksellers Ass'n v. Hudnut, 771 F.2d 323, 334 (7th Cir.), aff'd, 475 U.S. 1001 (1985), the Supreme Court summarily affirmed the Seventh Circuit ruling invalidating an ordinance based upon model legislation drafted by feminist pro-censorship leaders Andrea Dworkin and Catharine MacKinnon.

230. See generally A. DWorkin, Pornography: Men Possessing Women (1981) (pornography is not mere expression but method of domination of women); MacKinnon, Pornography, Civil Rights, and Speech, 20 Harv. C.R.-C.L. L. REv. 1 (1985) (same). Some feminists reject the notion that censoring pornography advances women's equality; they believe, to the contrary, that censoring pornography perpetuates archaic stereotypes about women. See Strossen, The Convergence of Feminist and Civil Liberties Principles in the Pornography Debate (Book Review), 62 N.Y.U. L. REV. 201 
suade courts and legislatures to invalidate sexist actions. ${ }^{231}$ A decade ago, civil libertarians and several courts-including the Supreme Court-rejected the plea of Holocaust survivors in Skokie, Illinois to prohibit neo-Nazis from demonstrating. ${ }^{232}$ Instead, civil libertarians successfully have lobbied for the enactment and enforcement of laws against anti-Semitic vandalism and other hate-inspired conduct. ${ }^{233}$

A pervasive weakness in Professor Lawrence's analysis is his elision of the distinction between racist speech, on the one hand, and racist conduct, on the other. ${ }^{234}$ It is certainly true that racist speech, like other speech, may have some causal connection to conduct. As Justice Holmes observed, "[e]very idea is an incitement" to action. ${ }^{235}$ However, as Justice Holmes also noted, to protect speech that advocates conduct you oppose does not "indicate that you think the speech impotent, ... or that you do not care wholeheartedly for the result." ${ }^{236}$ Rather, this protection is based on the critical distinction between speech that has a direct and immediate link to unlawful conduct and all other speech, which has less direct and immediate links. In Holmes' immortal words:

[W]e should be eternally vigilant against attempts to check the expression of opinions that we loathe and believe to be fraught with death, unless they so imminently threaten immediate interference with the lawful and pressing purposes of the law that an immediate check is required to save the country.... Only the emergency that makes it immediately dangerous to leave the correction of evil counsels to time warrants making any exception to the sweeping command, "Congress shall make no law ... abridging the freedom of speech."237

Justice Holmes' stirring phrases were penned in dissenting opinions. However, the Court enshrined his view as the law of the land in 1969, in

(1987) (reviewing WoMEN AGAINST CENSORSHIP (V. Burstyn ed. 1985)) (book demonstrates falseness of dichotomy between feminist and civil libertarian principles, since goal of both is society in which individuals are treated justly).

231. For a description of ACLU efforts to combat sex discrimination, see Gale \& Strossen, supra note 19 , at $168-84$.

232. Collin v. Smith, 447 F. Supp. 676 (N.D. III.), aff'd, 578 F.2d 1197 (7th Cir.), cert. denied, 439 U.S. 916 (1978); Village of Skokie v. National Socialist Party, 69 Ill. 2d 605, 373 N.E.2d 21 (1978).

233. See Letter from Morton Halperin to author, at 2 (Feb. 5, 1990) (ACLU strongly supported federal legislation directing FBI to gather statistics on hate crimes) (available from author).

234. See Lawrence, at $438-44$. See, e.g., id. at 440 n.42 ("racist conduct amounts to speech"); id. at 441 ("Brown's declaration that segregation is unconstitutional amounts to a regulation of the message of white supremacy."); id. at $443 \mathrm{n.58}$ ("I want to stress the complete overlap of the idea and practice of racism."); id. at 444 ("[T]he Court recognized the inseparability of idea and practice in the institution of slavery."); id. at 446 ("Brown mandates the abolition of racist speech."); id. at 463 ("Brown is a case about group defamation.").

235. Gitlow v. New York, 268 U.S. 652, 673 (1925) (Holmes, J., dissenting).

236. Abrams v. United States, 250 U.S. 616, 630 (1919) (Holmes, J., dissenting).

237. Id. at $630-31$. 
Brandenburg v. Ohio. 238 In a unanimous opinion overturning the conviction of a $\mathrm{Ku}$ Klux Klansman for an anti-black and anti-Semitic speech, the Court said that the first amendment does "not permit a state to forbid ... advocacy of the use of force or of law violation except where such advocacy is directed to mciting or producing imminent lawless action and is likely to incite or produce such action."239

It is impossible to draw a bright hine between speech and conduct. It also may be difficult to determine whether certain speech has a sufficiently tight nexus to conduct to justify regulating that speech. Professor Lawrence, however, abandons the attempt to make any such distinctions at all. He treats even the most extreme, blatant discriminatory conduct as speech, including slavery itself. ${ }^{240}$ Although undoubtedly harmful, the utterance of disparaging remarks cannot be equated fairly with the systematic denial of all rights to a group of human beings. ${ }^{241}$ Professor Lawrence recognizes this and appropriately chides anyone who insists that all racist conduct that includes an expressive component should be treated alike-namely, as protected speech. ${ }^{242}$ However, Professor Lawrence himself engages in precisely the same kind of oversimplification when he suggests that all conduct with an expressive component-which, in his view, includes all racist conduct and all racist speech ${ }^{243}$-should be treated alike, namely, as unprotected speech. Those of us who reject either extreme as unreasonably rigid should join forces in undertaking the essential, albeit difficult, task of line-drawing. ${ }^{244}$

\section{Proscription on Content-Based Speech Regulations.}

a. The indivisibility of free speech. It is important to place the current debate about campus racist speech in the context of earlier efforts to censor other forms of hate speech, including sexist and anti-Semitic

238. 395 U.S. 444 (1969) (per curiam).

239. Id. at 447.

240. See supra note 234.

241. Slavery, as well as de jure segregation and other phenomena that Professor Lawrence assimilates to hate speech by students or faculty members, also are distinguishable on the additional ground that the former emanated from the government, and the latter from private individuals. Regarding the significance of this distinction, see infra text accompanying notes 299-321.

242. See Lawrence, at $438,449,457,461,473-74,476$.

243. See id. at $438-49$.

244. Indeed, Professor Lawrence himself emphasizes that he advocates regulating only a narrow class of racist speech. See $i d$. at $435-36,450$ n.82, 458, 472. Therefore, he apparently recoguizes that his equation between racist speech and racist conduct-whatever theoretical appeal it might haveis not relevant to the task of deeiding which subset of racist speech should be restricted. However, while rejecting the speech/conduct line between protected and unprotected expressive activity, he offers no other. For a further discussion of this issue in the particular context of Professor Lawrence's argument that Brown v. Board of Education sanctions regulating racist speech, see infra text accompanying notes $289-98$. 
speech. ${ }^{245}$ Such a broadened perspective suggests that consistent principles should be applied each time the issue resurfaces in any guise. Every person may find one particular type of speech especially odious and one message that most sorely tests his or her dedication to free speech values. But for each person who would exclude racist speech from the general proscription against content-based speech regulations, recent experience shows that there is another who would make such an exception only for anti-choice speech, another who would make it only for sexist speech, another who would make it only for anti-Semitic speech, another who would make it only for flag desecration, and so on.

The recognition that there is no principled basis for curbing speech expressing some particular ideas is reflected in the time-honored prohibition on any content-based ${ }^{246}$ or viewpoint-based ${ }^{247}$ regulations. As stated by Professor Tribe, "If the Constitution forces government to allow people to march, speak and write in favor of peace, brotherhood, and justice, then it must also require government to allow them to advocate hatred, racism, and even genocide."248

The position stated by Professor Tribe is not just the traditional civil libertarian view, but it also is the law of the land. The courts consistently have agreed with civil libertarian claims that the first amendment protects the right to engage in racist and other forms of hate speech. ${ }^{249}$ Why is this so, and should it be so? Professor Lawrence rightly urges us to take a fresh look at this issue, no matter how well-settled it is as a matter of law. I have taken that invitation seriously and reflected long and hard upon his thought-provoking article and the questions it presents. Having done so, however, I conclude that the courts and traditional civil libertarians are correct in steadfastly rejecting laws that create additional new exceptions to free speech protections for racist expression.

245. See supra notes $227-33$ and accompanying text.

246. See, eg., Police Dep't of Chicago v. Mosley, 408 U.S. 92, 95 (1972) ("[A]bove all else, the First Amendment means that government has no power to restrict expression because of its message, its ideas, its subject matter, or its content."). Courts will sustain a content-based speech regulation only where the government can prove that it "is necessary to serve a compelling state interest and that it is narrowly drawn to achieve that end." Widmar v. Vincent, 454 U.S. 263, 270 (1981). This stringent showing can rarely be made. See, e.g., Carey v. Brown, 447 U.S. 455, 465 (1980) (statute prohibiting peaceful picketing in residential neighborhoods not narrowly tailored enough to promote State's asserted interests in (1) promoting privacy of home, and (2) providing special treatment for labor).

247. See supra quote accompanying note 1 .

248. L. TRIBE, supra note $58, \S 12-8$, at 838 n.17.

249. Justice Holmes enunciated this position in United States v. Schwimmer, 279 U.S. 644,654 (1929) (Holmes, J., dissenting) ("If there is any principle of the Constitution that more imperatively calls for attachment than any other it is the principle of free thought-not free thought for those who agree with us, but freedom for the thought that we hate."). 
One longstanding rationale for the view that speech must be protected, regardless of its content, is the behef that we need a free marketplace of ideas, open even to the most odious and offensive ideas and expressions, ${ }^{250}$ because truth ultimately will triumph in an unrestricted marketplace. ${ }^{251}$ The marketplace metaphor is subject to some criticism, as Professor Lawrence notes. ${ }^{252}$ Nevertheless, the marketplace of ideas does sometimes work to improve society: This has been particularly true with regard to promotion of racial equality. 253 Moreover, there are other, independently sufficient, rationales for the content-neutral protection even of hate speech. Another important, more recently articulated, rationale is that freedom of expression promotes individual autonomy and dignity. ${ }^{254}$ Professor Lawrence himself endorses an additional theory for the protection of racist speech, a view which recently was advanced by Dean Lee Bollinger: Free speech reinforces our society's commitment to tolerance and to combating racist ideas. 255

Although the foregoing theories inay be acceptable in general, one might ask why they do not permit exceptions for racist speech. Racism in America is umque in important respects. For most of our country's history, racisin was enshrined legally through slavery or de jure discrimination. The post-Civil War constitutional amendments guaranteed racial equality. More recently, all branches and levels of the government have

250. See, e.g., Watts v. United States, 394 U.S. 705, 708 (1969) (per curiam) (refers to a " 'profound national commitment to the principle that debate on public issues should be uninhibited, robust, and wide-open, and that it may well include vehement, caustic, and sometimes unpleasantly sharp attacks.' The language of the political arena . .. is often vituperative, abusive, and inexact" (quoting New York Times Co. v. Sullivan, 376 U.S. 254, 270 (1964))). The Supreme Court recently reaffirmed that the first amendment does not allow authorities to "prohibit the expression of an idea simply because society finds the idea offensive or disagreeable." Texas v. Johnson, $109 \mathrm{~S}$. Ct. 2533, 2544 (1989) (invalidating conviction for burning United States flag to express idea).

251. In a widely quoted dissent, Justice Holmes championed this rationale for free speech as "the theory of our Constitution":

[W] hen men have realized that time has upset many fighting faiths, they may come to believe even more than they believe the very foundations of their own conduct that the ultimate good desired is better reached by free trade in ideas - that the best test of truth is the power of the thought to get itself accepted in the competition of the market, and that truth is the only ground upon which their wishes safely can be carried out.

Abrams v. United States, 250 U.S. 616, 630 (1919) (Holmes, J., dissenting). See also Cohen v. California, 403 U.S. 15, 24 (1971) (free expression "will ultimately produee a more capable citizenry and more perfect polity"); New York Times, 376 U.S. at 270.

252. See infra text accompanying notes 416-21.

253. See infra text accompanying notes $429-36$.

254. See Cohen, 403 U.S. at 24 ("[N]o other approach [than protecting free speech] would comport with the premise of individual dignity and choice upon which our political system rests."); Richards, Free Speech and Obscenity Law: Toward a Moral Theory of the First Amendment, 123 U. PA. L. REv. 45, 62 (1974) (freedom of expression permits and encourages individual's exercise of autonomy).

255. See Lawrence, at 436. 
sought to implement these constitutional guarantees by outlawing any vestiges of state-sponsored, as well as many forms of private, racial discrimination. Given our nation's special obligation to eradicate the "badges and incidents" of the formerly government-sanctioned institutions of racism, is it not appropriate to make broader exceptions than usual to free speech doctrines for racist speech? As Professor Rodney Smolla has noted, "Racist speech is arguably different in kind from other offensive speech, because the elimination of racism is itself enshrined in our Constitution as a public value of the highest order."256

The American commitment to eradicate racial discrimination is reinforced by a parallel international commitment, as expressed in such documents as the United Nations Charter, ${ }^{257}$ the Universal Declaration of Human Rights, 258 and the International Convention on the Elimination of All Forms of Racial Discrimination. ${ }^{259}$ Moreover, the United States is apparently alone in the world community in sheltering racist speech. Both under international agreements ${ }^{260}$ and under the domestic law of many other countries ${ }^{261}$ racist speech is outlawed.

In hight of the umiversal condemnation of racial discrimination and the world-wide regulation of racist speech, it certainly is tempting to consider exceptimg racist speech from first amendment protection. Episodes of racist speech, such as those cited by Professor Lawrence and others, make a full commitment to free speech at times seem painful and diffcult. Civil libertarians find such speech abhorrent, given our dedication to eradicating racial discrimination and other forms of bigotry. But experience has confirmed the truth of the indivisibility principle articulated above: History demonstrates that if the freedom of speech is weakened for one person, group, or message, then it is no longer there for others. ${ }^{262}$ The free speech victories that civil libertarians have won in the context of defending the right to express racist and other anti-civil libertarian

256. R. SMOlla, Free SPEECh iN OPEN Culture (tentative title, forthcoming).

257. U.N. ChARTER art. 1, para. 3.

258. Universal Declaration of Human Rights, arts. 2, 7, 16, G.A. Res. 217 (III), 9 U.N. GAOR (3d Sess. pt. 1) at 71, U.N. Doc. A/810 (1948).

259. Opened for signature Mar. 7, 1966, 660 U.N.T.S. 195.

260. For example, the International Convention on the Elimination of All Forms of Racial Discrimination, id. art. 4(a), requires states to "declare as an offence punishable by law all dissemination of ideas based on racial superiority or hatred, [and] incitement to racial discrimination."

261. See Kretzmer, Free Speech and Racism, 8 CARdozo L. Rev. 445, $499-506$ (1987) (reviewing European anti-hate speech laws).

262. See supra text accoinpanying note 1. As Thomas Paine wrote during our country's formative period: "He that would inake his own liberty secure, must guard even his enemy from oppression, for if he violates this duty, he establishes a precedent that will reach himself." (quoted in american Civil Liberties Union, Why the American Civil Liberties Union Defends FREE SPEeCh FOR RACISTS AND TOTALITARIANS 2 (n.d.) [hereinafter ACLU pamphlet]). 
messages have been used to protect speech proclaiming anti-racist and pro-civil libertarian messages. For example, in 1949, the ACLU defended the right of Father Terminiello, a suspended Catholic priest, to give a racist speech in Chicago. The Supreme Court agreed with that position in a decision that became a landmark in free speech history. ${ }^{263}$ Time and agam during the 1960s and 1970s, the ACLU and other civil rights groups were able to defend free speech rights for civil rights demonstrators by relying on the Terminiello decision. ${ }^{264}$

b. The slippery slope dangers of banning racist speech. To attempt to craft free speech exceptions only for racist speech would create a significant risk of a slide down the proverbial "slippery slope." To be sure, lawyers and judges are capable of-indeed, especially trained in-drawing distinctions between similar situations. Therefore, I agree with Professor Lawrence and other critics of the absolutist position ${ }^{265}$ that slippery slope dangers should not be exaggerated. It is probably hyperbole to contend that if we ever stepped off the mountaintop where all speech is protected regardless of its content, then inevitably we would end up in the abyss where the government controls all our words. ${ }^{266}$ On the other hand, critics of absolutism should not minimize the real danger: We would have a difficult time limiting our descent to a single downward step by attempting to prohibit only racist expression on campus. ${ }^{267} \mathrm{Ap}-$ plicable rules and supporting rationales would need to be crafted carefully to distinguish this type of speech from others.

First, we must think hard about the groups that should be protected. Should we regulate speech aimed only at racial and ethnic groups, as the University of Texas is considering? ${ }^{268}$ Or should we also bar insults of religious groups, women, gays and lesbians, individuals with disabilities, Vietnam War veterans, and so on, as do the rules adopted by Stanford and the University of Michigan? As the coinmittee that formulated the

263. Terminiello v. Chicago, 337 U.S. 1 (1949) (ACLU appeared amicus curiae); see also Brandenburg v. Ohio, 395 U.S. 444 (1969) (per curiam) (upholding free speech rights of Ku Klux Klan leader represented by ACLU).

264. See, e.g., Brown v. Louisiana, 383 U.S. 131, 135 (1966); Cox v. Louisiana, 379 U.S. 536, 552 (1965). See also infra text accompanying notes 423-28 (discussing important role which first amendment rights played in the civil rights movement).

265. See Minow, On Neutrality, Equality \& Tolerance: New Norms for a Decade of Distinction, Change, Jan./Feb. 1990, at 17.

266. As Professor Lawrcnce notes, see C. Lawrence, Presentation at ACLU Biennial Conference, supra note $t$, at 20 n.42, the Court has long upheld certain content-based speech regulations, such as those governing obscenity, without eviscerating all free speech rights.

267. Professor Lawrence recognizes this danger. See Lawrence, at 458 \& n. 106 (general societal tolerance for suppressing speech would pose dangerous precedent for speech of all dissenters, even without case law).

268. See University of Texas Report, supra note 115 , at 10. 
University of Texas's proposed rule pointed out, each category requires a separate evaluation, since each "raise[s] different policy and legal concerns."269 Therefore, we should not play fast and loose with the first aniendnient by casually expanding the categories of proscribed hate speech.

Second, we nuust carefully define proscribable harassing speech to avoid encoinpassing the important expression that inevitably is endangered by any hate speech restriction. Censorial consequences could result froin niany proposed or adopted university policies, including the Stanford code, which sanctions speech intended to "insult or stigmatize" on the basis of race or other prohibited grounds. For example, certain feninists suggest that all heterosexual sex is rape because heterosexual men are aggressors who operate in a cultural climate of pervasive sexism and violence agamst women. ${ }^{270}$ Aren't these feminists insulting or stignatizing heterosexual men on the basis of their sex and sexual orientation? And how about a Holocaust survivor who blames all ("Aryan") Germans for their collaboration during World War II? Doesn't this insinuation insult or stigmatize on the basis of national and ethnic origin? And surely we can think of numerous other examples that would have to give us pause.

The difficulty of formulating limited, clear definitions of prohibited hate speech, that do not encompass valuable contributions to societal discourse, is underscored by the seemingly intractable anibiguities in various campus rules. ${ }^{271}$ Even proponents of campus hate speech regulations recognize their inevitable ambiguities and contextualized applications, ${ }^{272}$ with the result that the individuals who enforce them must have substantial discretion to draw distinctions based upon the particular facts and circumstances involved in any given case. Professor Richard Delgado, an early advocate of rules proscribing hate speech, acknowledged that the offensiveness of even such a traditionally insulting epithet as "nigger" would depend on the context in which it was uttered, since it could be a term of affection when exchanged between friends. ${ }^{273}$ The imprecise na-

269. Id.

270. See Duggan, Hunter \& Vance, False Promises: Feminist Antipornography Legislation in the U.S., in WoMen Against Censorship 130, 134, 138-39, 146-47 (V. Burstyn ed. 1985); Snitow, Retrenchment Versus Transformation: The Politics of the Antipornography Movement, in id. at 118.

271. See supra text accompanying notes 206-21.

272. See Matsuda, supra note 13, at 2373.

273. Delgado, Words that Wound: A Tort Action for Racial Insults, Epithets, and Name-Calling, 17 Harv. C.R.-C.L. L. Rev. 133, 179-80 (1982). According to Professor Delgado,

[A]n epithet such as "You damn nigger" would almost always be found actionable, as it is highly insulting and highly racial .... "Boy," directed at a young black male, might be actionable, depending on the speaker's intent, the hearer's understanding, and whether a reasonable person would consider it a racial insult in the particular context. "Hey, nig- 
ture of racist speech regulations is underscored further by the fact that even their proponents are unsure or disagree as to their apphicability in particular situations. ${ }^{274}$

Once we acknowledge the substantial discretion that anti-hate speech rules will vest in those who enforce them, then we are ceding to the government the power to pick and choose whose words to protect and whose to punish. Such discretionary governmental power is fundamentally antithetical to the free speech guarantee. Once the government is allowed to punish any speech based upon its content, free expression exists only for those with power.

\section{c. The content-neutrality principle reflects sensitivity to hate speech's} hurtful power. Contrary to Professor Lawrence's apparent assumption, ${ }^{275}$ the conclusion that free speech protections must remain indivisible, even for racist speech, has nothing to do with insensitivity to the feelings of minority group members who are vilified by hate speech and suffer acutely from it. Traditional civil libertarians recognize the power of words to inflict psychic and even physical wounds.276 For example, precisely because the ACLU both acknowledges the power of speech and defends the exercise of that power even by those who express anti-civil libertarian ideas, the ACLU expressly dissociates itself from such ideas and makes it a priority to combat them through counterspeech and action. ${ }^{277}$ Nor are traditional civil libertarians unconcerned with the rights of hate speech victims, as Professor Lawrence implies. 278 To the con-

ger," spoken affectionately between black persons and used as a greeting, would not be actionable. An insult such as "You dumb honkey," directed at a white person, could be actionable ... but only in the unusual situations where the plaintiff would suffer harm from such an insult.

Id.

274. For example, during a discussion about the University of Wisconsin rule regulating hate speech, even advocates of the rule disagreed as to whether it would (or should) apply to the following hypothetical situation: A white student sits down next to a black student and says, "I want you to know that I'm a racist and hate the idea of blacks being here at the university," but does not use any racist epithet. Telephone interview with Eunice Edgar, Executive Director of ACLU of Wisconsin (Nov. 14, 1989). See also Gottlieb, supra note 4 (Professor Thomas Grey, who drafted Stanford code, "said his rule probably wouldn't apply to one of the most publicized racial incidents at Stanford, when a white student left on a black student's door a poster of Beethoven drawn as a black caricature.") (emphasis added).

275. See Lawrence, at 458-59.

276. See Matsuda, supra note 13, at 2336 ("Victims of vicious hate propaganda have experienced physiological symptoms and emotional distress ranging from fear in the gut, rapid pulse rate and difficulty in breathing, nightmares, post-traumatic stress disorder, hypertension, psychosis, and suicide.").

277. See supra note 53 (quoting relevant ACLU policy).

278. See Lawrence, at $448,456,458,478$. 
trary, civil libertarians champion the rights of all individuals to live in a society untainted by racism and other forms of bias. ${ }^{279}$

I was appalled by Professor Lawrence's account of the vicious racist vilification to which his sister's family recently was subjected. ${ }^{280}$ This account powerfully demonstrates that the old nursery rhyme is wrong: Maybe words are different from sticks and stones insofar as they cannot literally break our bones, but words can and do hurt-brutally.

Two prominent defenders of content-neutral protection for hate speech have described painful personal experiences as victims of such speech. I refer to Stanford Law Professor Gerald Gunther, who was a leading opponent of the proposed Stanford code which Professor Lawrence advocates, ${ }^{281}$ and Aryeh Neier, who as Executive Director of the ACLU during the Skokie episode vigorously championed the free speech riglits of racists and anti-Semites. ${ }^{282}$ Far from opposing censorship despite the suffering they personally experienced as a result of hate speech, Messrs. Gunther ${ }^{283}$ and Neier ${ }^{284}$ oppose censorship precisely because of

279. For ACLU policies opposing racism and other types of bias, see supra notes $11 \& 15$ and Appendix; for ACLU efforts to combat discrimination, see supra note 16 and infra text accompanying notes 336-55.

280. See Lawrence, at 460 . It should be stressed, however, that this expression would not be encompassed by either the Stanford code or Professor Lawrence's variation on it. See supra notes 205-06.

281. See Letter from Professor Gerald Gunther to Professor George Parker, Chair of the Student Conduct Legislative Council, Stanford University (Mar. 10, 1989), reprinted in Stanford Univ. Campus Rep., Mar. 15, 1989, at 17 [hereinafter Gunther letter (March 10, 1989)]. Gunther wrote that:

[L]est it be said that I unduly slight the pain imposed by expressions of racial or religious hatred let me add that I have suffered that pain. I cmpathize with others who have, and I rest my deep behief in the principles of the First Amendment in part on my own experiences.

I received my elementary education in a public school in a very small town in Nazi Germany. I was subjeeted to vehement anti-Semitic remarks, from my teacher, my classmates and others. "Judensau" (Jew pig) was far from the harshest.

282. See A. NEler, supra note 63, at 2-3 (recounting his childhood as a Jew in Hitler's Gcrmany, his narrow escape from the Nazi death camps, and the extermination of almost all his relatives, beyond his immediate family, during World War II).

283. Professor Gunther stated that:

My own experiences have certainly not led me to be insensitive to the myriad pains offensive speech can and often does impose. But the lesson I have drawn from my childhood in Nazi Germany and my happier adult life in this country is the need to walk the sometimes difficult path of denouncing the bigots' hateful ideas with all my power yet at the same time challenging any community's attempt to suppress hateful ideas by force of law.

Gunther letter (March 10, 1989), supra note 281.

284. Aryeh Neier, reflecting on his role in the Skokie incident, recalled that:

The most frequently repeated line of all in the many letters about Skokie that I received was: "How can you, a Jew, defend freedom for Nazis?". ... The response I made ... most often began with a question: "How can I, a Jew, refuse to defend freedom, even for Nazis? ..." Because we Jews are uniquely vulnerable, I believe we can win only brief respite from persecution in a society in which encounters are settled by power. As a Jew, therefore ...1 want restraints plaeed on power.... I want restraints which prohibit those in power from interfering with my right to speak, my right to publish, or my right to gather with others 
these personal experiences. The justification for not outlawing "words that wound"28s is not based on a failure to recognize the injurious potential of words. The refusal to ban words is due precisely to our understanding both of how very powerful they are and of the critical role they play in our democratic society. ${ }^{286}$

\section{Professor LaWrence's Rationales for Regulating Racist Speech Would Justify Sweeping Prohibitions, Contrary to Free Speech Principles}

Although Professor Lawrence actually advocates regulating only a relatively narrow category of racist speech, his rationales could be asserted to justify broader rules. Indeed, he himself appears to recognize that, if accepted, his approach could lead to outlawing all racist speech, as well as other forms of hate speech. ${ }^{287}$ Since many universities and individuals now advocate broader-ranging regulations-and since Professor Lawrence also endorses restrictions that have a "considerably broader reach" than the Stanford code ${ }^{288}$-it is important to consider the problems with Professor Lawrence's more expansive rationales. His general theories about racist speech entail substantial departures from traditional civil libertarian and constitutional law positions.

\section{A. Brown and Other Cases Invalidating Governmental Racist Conduct Do Not Justify Regulating Non-Governmental Racist Speech}

Professor Lawrence intriguingly posits that Brown v. Board of Education, ${ }^{289}$ Bob Jones University v. United States, ${ }^{290}$ and other civil rights cases justify regulation of private racist speech. ${ }^{291}$ The problem with drawing an analogy between all of these cases and the subject at hand is that the cases involved either government speech, as opposed to speech

who also feel threatened. . . . To defend myself, I must restrain power with freedom, even if the temporary beneficiaries are the enemies of freedom.

A. NEIER, supra note 63, at 4-5.

285. See Delgado, supra note 273 , at 133.

286. See Gale \& Strossen, supra note 19, at 171. In their article, the authors stated that:

We know that free speech poses great personal and societal risks, and that the risks are borne, unfairly and disproportionately, by individuals and groups that any just and humane society would single out instead for respect, compassion, help, and even reparation for past wrongs. But we also know that racism, sexism, and silence have combined too often to form an unholy trinity in the history of oppression in the United States.

287. See supra text accompanying notes 28-31.

288. Lawrence, at 456. See also supra note 27.

289. 347 U.S. 483 (1954).

290. 461 U.S. 574 (1983).

291. See Lawrence, at 438-49. 
by private individuals, or conduct, as opposed to speech. ${ }^{292}$ Indeed, Brown itself is distinguishable on both grounds.

1. The Speech/Conduct Distinction. First, the governmental defendant in Brown - the Topeka, Kansas Board of Education-was not simply saying that blacks are inferior. Rather, it was treating them as inferior through pervasive patterns of conduct, by maintaining systeins and structures of segregated public schools. To be sure, a by-product of the challenged conduct was a message, but that message was only incidental. Saying that black children are unfit to attend school with whites is materially distimguishable froin legally prohibiting thein froin doing so, despite the fact that the legal prohibition may convey the former message.

Professor Lawrence's point proves too inuch. If incidental inessages could transform conduct into speech, then the distinction between speech and conduct would disappear completely, because all conduct conveys a message. To take an extreme example, a racially motivated lynching expresses the murderer's hatred or contempt for his victim. But the clearly unlawful act is not protected from punishinent by virtue of the incidental message it conveys. And the converse also is true. Just because the government may suppress particular hate messages that are the by-product of unlawful conduct, it does not follow that it may suppress all hate messages. Those inessages not tightly linked to conduct unust still be protected. ${ }^{293}$

Professor Lawrence's argument is not advanced by his unexceptionable observation that all human activity nay be described both as "speech" and as "conduct." All speech entails some activity (e.g., the act of talking) and all conduct expresses some message. ${ }^{294}$ First, this fact does not justify treating any speech-conduct as unprotected; second, it does not justify eliminating protection from the particular class of speech-conduct that Professor Lawrence deems regulable.

The fact that there is no clear distinction between speech and conduct does not necessarily warrant limiting the scope of protected speechconduct; ${ }^{295}$ instead, the lack of a clear distinction could as logically war-

292. Regarding the significance of this distinction, see supra text accompanying notes 234-41.

293. See supra notes $73-74$ and accompanying text.

294. See Lawrence, at 440 n.43.

295. For example, as Professor Lawrence observes, id., John Hart Ely has described all communicative behavior as " $100 \%$ action and $100 \%$ expression." Ely, Flag Desecration: $A$ Case Study in the Roles of Categorization and Balancing in Fist Amendment Analysis, 88 HaRv. L. REv. 1482, 1495-96 (1975). This does not lead Professor Ely, however, to conclude that all speech should be regulated. Nor does it lead him to conclude that the speech/conduct distinction is irrelevant to first amendment analysis. Rather, he suggests that, in evaluating the constitutionality of a government 
rant expanding the scope of protection. Although one could argue-as does Professor Lawrence-that some speech is tantamount to conduct and should therefore be regulated, one could also argue that some conduct is tantamount to speech and therefore should not be regulated. This latter approach has characterized a lime of Supreme Court decisions that protect various forms of conduct, ranging from labor picketing ${ }^{296}$ to burning the American flag, 297 as "symbohic speech."

The absence of a clear distinction between speech and conduct also does not support Professor Lawrence's particular concept of regulable racist speech. Even assummg that his wholesale abandonment of the traditional distimction is warranted with respect to racist words and deeds, Professor Lawrence himself apparently concedes that this still would not justify the regulation of all racist words. To the contrary, he advocates regulating only a limited class of such words. But if Professor Lawrence does not draw the line between regulable and non-regulable racist speech on the basis of the speech/conduct dichotomy, on what basis does he draw that hine? He does not offer a clear himiting principle

regulation of certain conduct, the analytical focus should not be on whether that conduct should be classified as "speech" or "action." Instead, he urges, the relevant inquiry should be whether the regulation is aimed at the expressive aspect of such conduct. If so, it is presumptively unconstitutional; if not, it is presumptively constitutional. Id. at 1496-97. This is the analysis that the Court enunciated in United States v. O'Brien, 391 U.S. 367, 381-82 (1968) (upholding statute that criminalized the destruction of draft cards where governmental interest was limited to the noncommunicative aspect of defendant's conduct).

Under the Ely-O'Brien analysis, Brown does not involve the regulation of the expressive aspect of speech-conduct. Under the $O$ 'Brien test, as Professor Ely paraphrased it, "[t]he critical question ... [is] whether the harm that the state is seeking to avert is one that grows out of the fact that the defendant is communicating ... or rather would arise even if the defendant's conduct had no communicative siguificance whatsocver." Ely, supra, at 1497. Analysis reveals that school segregation would be invalidated apart from its communicative significance.

One can imagine situations in which the act of requiring schools to be racially segregated did not convey the message of white supremacy which Professor Lawrence views as the central meaning of sehool scgregation. See Lawrence, at 441, 462-64. Yet Brown surely would hold that such segregated schools violate the equal protection clause. For example, a black student who had been raised in a different culture marked by black supremacy, and then moved to the U.S. and attended a racially segregated school, might well interpret school segregation as conveying the message of white inferiority. Would Brown not demand that this student should nonetheless attend a desegregated school? As another example, a community might come to view racial diversity much the way it regards religious diversity, so that the choice to attend a religiously segregated school would be viewed as conveying no more stigmatizing a message than the choice to attend a religiously segregated school. Would Brown not insist, nevertheless, that no public schools could be racially segregated, even if the option of attending them was completely voluntary? See Green v. County School Bd., 391 U.S. 430 (1968) (rejected "freedom-of-choice" plan for desegregation).

296. See, e.g., Thornhill v. Alabama, 310 U.S. 88 (1940) (peaceful picketing to publicize labor dispute is constitutionally protected free speech).

297. See United States v. Eichman, 110 S. Ct. 2404, 2409-18 (1990); Texas v. Johnson, 109 S. Ct. 2533, 2539 (1989) (Flag burning is "conduct sufficiently imbued with elements of communication to implicate the first amendment."). 
for distinguishing the racist speech that should be regulated from the entire corpus of racist speech, which he views as conduct, and hence presumptively regulable under the speech/conduct approach. ${ }^{298}$

2. The Private Action/State Action Distinction. Even if Brown involved only a governmental message of racism, without any attendant conduct, that case still would be distimguishable in a crucial way from a private individual's conveyance of the same message. Under the postCivil War constitutional amendments, the government is committed to eradicatimg all badges and mcidents of slavery, including racial discrimination. Consistent with the paramount importance of this obligation, the Supreme Court has held that the equal protection clause bars the government from loaming textbooks to racially discriminatory private schools, ${ }^{299}$ even though the Court had held previously that the establishment clause does not bar the government from loaning textbooks to private rehigious schools. ${ }^{300}$ In this respect, the government's constitutional duty to dissociate itself from racism is even greater than its constitutional duty to dissociate itself from religion. ${ }^{301}$ The government's supreme obligation to counter racism clearly is mcompatible with racist speech promulgated by the government itself. Private individuals have no comparable duty.

Professor Mari Matsuda has argued that the government's failure to punish private hate speech could be viewed as state action insofar as this failure conveys a message that the state tolerates such speech. ${ }^{302}$ Because the Court construes the establishınent clause as prohibiting government

298. The fact that Professor Lawrence also rejects the state action doctrine as a limiting principle on government's regulatory power further expands the range of speech that he would allow to be restricted. See Lawrence, at 444-49.

Scholars constantly grapple with the complex problems of how to separate regulable from nonregulable speech. For recent efforts, see C. BAKER, HUMAN LiberTy aND FreEDOM OF SPEeCH (1989); K. Greenawalt, SPEech, CRime, AND the Uses of LANGuAGe (1989); H. KALVEN, JR., A Worthy Tradition: FreEdom OF SPEECH IN AMERICA (1988); F. SCHAUER, FreE SPEECH: A PHILOSOPHICAL ENQUiRY (1982). Yet I am unaware of any that provide a more coherent basic approach than the Court's current general framework: A government regulation aimed at speech or expressive conduct is presumptively unconstitutional unless "it furthers an important . . governmental interest ... [that] is unrelated to the suppression of free expression ... [andl the incidental restriction on .... First Amendment freedoms is no greater than is essential to the furtherance of that interest." United States v. O'Brien, 391 U.S. 367, 377 (1968). If speech is integrally interrelated with, or incites, violent or otherwise unlawful conduct, government regulation would be permitted under the $O$ 'Brien formulation. See supra notes 73-74 and accompanying text.

299. Norwood v. Harrison, 413 U.S. 455, 471 (1973).

300. Board of Educ. v. Allen, 392 U.S. 236, 248 (1968).

301. See Nonwood, 413 U.S. at 470 ("However narrow may be the channel of permissible state aid to sectarian schools, . . . it permits a greater degree of state assistance than may be given to private schools which engage in discriminatory practices.").

302. See Matsuda, supra note 13, at 2378-79. 
action that conveys a message of state support for religion, ${ }^{303}$ establishment clause cases constitute instructive precedents for evaluating Professor Matsuda's argument. ${ }^{304}$ In the analogous establishment clause context, the Court repeatedly has held that the government's neutral tolerance and protection of private religious expression, along with all other expression, does not convey a message that the government endorses religion. ${ }^{305}$ In its 1990 decision in Board of Education of Westside Community Schools v. Mergens, ${ }^{306}$ the Court expressly reaffirmed the crucial distinction between government and private speech, in the establishment clause context, in terms fully applicable to the racist speech controversy. The Court declared, "[T] here is a crucial difference between government speech endorsing religion, which the Establishment Clause forbids, and private speech endorsing religion, which the Free Speech and Free Exercise Clauses protect."307 Paraphrasing this language and applying it to the campus hate speech context, one could say, "There is a crucial difference between government speech endorsing racism, which the Equal Protection Clause forbids, and private speech endorsing racisin, which the Free Speech Clause protects."

In light of the government's special duty to dissociate itself from racism, one might try to distinguish private religious speech from private racist speech-inuch as the Court distinguished textbook loans to racially discriminatory private schools from the same kind of loans to private religious schools. ${ }^{308}$ However, the direct, tangible, explicit government support of racially discriminatory schools through textbook lending programs is critically different from the indirect, intangible, implicit government support allegedly lent to racist conduct by the government's failure to outlaw private racist speech. ${ }^{309}$

303. See, e.g., County of Allegheny v. ACLU, 109 S. Ct. 3086, 3101 (1989) (establishment clause inquiry is whether government is "conveying or attempting to convey a message that religion or a particular religious belief is favored or preferred").

304. Professor Lawrence also suggests the-analogy between establishment clause doctrine and the law goveming race discrimination. See Lawrence, at 447 ("for over three hundred years, racist speech has been the liturgy of America's leading established religion, the religion of racism").

305. Board of Educ. v. Mergens, 110 S. Ct. 2356 (1990) (interpreting Equal Access Act, 20 U.S.C. $\$ \S 4071-4074$ (1988), which prohibits public secondary schools from denying meeting space to religious and other clubs on the basis of speech content, expresses neutrality towards religion); Widmar v. Vincent, 454 U.S. 263, 271-72 (1981) (when university has created a forum generally open to student groups, its content-based exclusion of religious speech violates principle that regulation should be content-neutral).

306. 110 S. Ct. 2356 (1990).

307. Id. at 2372 (emphasis added).

308. See supra text accompanying notes 299-300.

309. See Norwood v. Harrison, 413 U.S. 455, 466 (1973) (state may not grant "tangible financial aid ... if [it] has a significant tendency to facilitate, reinforce, and support private discrimination"); 
Professor Lawrence makes a telling point when he says that our government never has repudiated the group libels it perpetrated for years against blacks and that it is insufficient for the government simply to cease uttering those libels. ${ }^{310}$ One approach for proinoting racial equality, which is consistent with free speech, is to urge the government to proclaim anti-racist messages. ${ }^{311}$

Professor Lawrence also makes the persuasive point that there is no absolute distinction between state and private action in the racist sphere, insofar as private acts of discrimination (as well as government acts) also are unlawful. ${ }^{312}$ This point, however, raises the other distinction discussed above - the distinction between words and conduct. Civil libertarians vigorously support the civil rights laws that make private discriminatory acts illegal, ${ }^{313}$ but that is a far cry from making private speech illegal. The Bob Jones case, upon which Professor Lawrence seeks to rely, ${ }^{314}$ illustrates these distinctions. What was objectionable there was the government conduct that supported and endorsed the private racist conduct-namely, the governinent's making of financial contributions, through the tax systein, to racially discriminatory private educational institutions. Moreover, even if a private university could be prohibited froin taking discriminatory actions-in the case of Bob Jones University, barring interracial marriage and dating-it still could not be prohibited from advocating such actions. The ACLU anicus brief in the Bob Jones case ${ }^{315}$ inade precisely these points in countering the University's claim that withdrawing its tax benefits would violate its first amendment rights. The ACLU argued, ${ }^{316}$ and the Court agreed, ${ }^{317}$ that the University was still free to urge its students not to engage in interra-

id. at 467 (state must not give "significant aid" to racially discriminatory private institutions); id. at 469 (discriminatory private schools may not receive "material aid" from state).

310. Lawrence, at 447.

311. See infra text accompanying notes $397-402$.

312. See Lawrence, at 449.

313. See infra text accompanying notes 338-55 (outlining ACLU's efforts to combat racism). The ACLU joined an amicus brief filed by a coalition of civil rights organizations in Patterson $v$. McLean Credit Union, 109 S. Ct. 2363 (1989), endorsing the Court's earlier interpretation of 42 U.S.C. $\$ 1981$ (1988) as outlawing private race discrimination, see Runyon v. McCrary, 427 U.S. 160,173 (1976) (section 1981 reaches private acts of discrimination).

314. See Lawrence, at 449.

315. Brief of the American Civil Liberties Union and the American Jewish Committee, Amici Curiae in support of Affirmance at 37-38, Bob Jones Univ. v. United States, 461 U.S. 574 (1983) (Nos. 81-3, 81-1).

316. Professor Strossen was counsel of record for the ACLU and the American Jewish Committee, amici curiae, advocating government denial of tax benefits to racially discriminatory educational institutions.

317. See Bob Jones, 461 U.S. at 603-04 ("Denial of tax benefits will inevitably have a substantial impact on the operation of private religious schools, but will not prevent those schools from observing their religious tenets."). Accord Runyon, 427 U.S. at 177 (42 U.S.C. $§ 1981$ (1988) forbids pri- 
cial marriage or dating, and this was as far as its first amendment rights extended. Prohibited racist acts are no different from other prohibited acts. The government may punish the acts, but it may not punish words that advocate or endorse them.

The other cases upon which Professor Lawrence premises his argument also do not authorize the regulation of private racist speech. For example, he attempts to analogize private racist speech to a local government's financing of allegedly "private" segregated (all-white) schools, after the government had closed down public schools in defiance of desegregation orders. ${ }^{318}$ Lawrence misreads these cases as standing for the proposition "that the defamatory message of segregation would not be insulated from constitutional proscription simply because the speaker was a non-government entity." 319 Another example is provided by Griffin v. Prince Edward County School Board, in which the Supreme Court held that the governmental financing of segregated schools constituted prohibited state action. ${ }^{320}$ In contrast, had individual school district residents urged their government to undertake such action, or expressed this opinion to black residents, that would have constituted protected private speech. ${ }^{321}$

\section{B. The Non-Intellectual Content of Some Racist Speech Does Not Justify its Prohibition}

In addition to his principal argument that private racist speech can be regulated because it is indistinguishable from governmental racist conduct, Professor Lawrence offers a second justification. He contends that "[a] defining attribute of speech is that it appeals first to the mind of the hearer who can evaluate its truth or persuasiveness," 322 and that because certain racist speech lacks this quality, it should not be viewed as speech. This position is inconsistent with fundamental free speech values.

vate, commercially operated, nonsectarian schools from denying admission based on race, but such schools remain free "to inculcate whatever values and standards they deem desirable.").

318. See Lawrence, at 448 \& n.75.

319. Id. at 448 .

320. 377 U.S. 218, 233 (1964).

321. Equally unpersuasive is Professor Lawrence's attempted reliance on cases upholding prohibitions upon race-designated advertisements for employees, home sales, and rentals, see Lawrence, at 449 \& n.81, 464 n.123. As the Supreme Court ruled, in Pittsburgh Press Co. v. Human Relations Comm'n, 413 U.S. 376, 391 (1973), these advertisements constituted integral elements of the prohibited discriminatory conduct-i.e., refusing to hire women. Id. at 388-89. Therefore, these advertisements fit within the general category of speech that may be regulated on the ground that it constitutes an essential element of an unlawful act. See supra notes 73-74 and accompanying text.

322. Lawrence, at 452 n.87. 
Lawrence's argument overlooks the teachings of such landmark Supreme Court decisions as Terminiello v. Chicago ${ }^{323}$ and Cohen v. California, ${ }^{324}$ which hold that protectible speech often appeals to the emotions as well as the mind. As early as 1948, the Court recognized that first amendment protection is not restricted to the "exposition of ideas." 325 As Justice Douglas declared in a celebrated passage in Terminiello:

[A] function of free speech under our system of government is to invite dispute. It may indeed best serve its high purpose when it induces a condition of unrest, creates dissatisfaction with conditions as they are, or even stirs people to anger. Speech is often provocative and challenging. It may strike at prejudices and preconceptions and have profound unsettling effects as it presses for acceptance of an idea. That is why freedom of speech, though not absolute, is nevertheless protected against censorship or punishment, unless shown likely to produce a clear and present danger of a serious substantive evil that rises far above public inconvenience, annoyance, or unrest. There is no room under our Constitution for a more restrictive view. For the alternative would lead to standardization of ideas either by legislatures, courts, or dominant political or community groups. 326

Justice Harlan ${ }^{327}$ echoed this theme in Cohen when he explained that protectible expression

conveys not only ideas capable of relatively precise, detached explication, but otherwise inexpressible emotions as well. In fact, words are often chósen as much for their emotive as their cognitive force. We cannot sanction the view that the Constitution, while solicitous of the cognitive content of individual speech, has little or no regard for that emotive function which practically speaking, may often be the more important element of the overall message sought to be communicated. ${ }^{328}$

323. 337 U.S. 1 (1949).

324. 403 U.S. 15 (1971).

325. Winters v. New York, 333 U.S. 507, 510 (1948) (reversing conviction for selling crime magazines under statute prohibiting publication of "stories of . . bloodshed, lust or crime" as obscene, id. at 508). The Court concluded that expression devoid of "ideas," but with entertainment value, was protected, because "[t]he line between the informing and the entertaining is too elusive for the protection of that basic [first amendment] right. ... What is one man's amusement, teaches another's doctrine." Id. at 510 .

326. Terminiello, 337 U.S. at $4-5$ (citations omitted). For a very different view, compare Lawrence, at 438 ("Regulations that require civility of discourse in certain designated forums are not incursions on intellectual and political debate.").

327. It is noteworthy that these two ringing endorsements of constitutional proteetion for offensive, provocative speech were written by Justices at opposite ends of the Court's ideological spectrum. The agreement on this issue between Justice Douglas, a noted liberal, and Justice Harlan, a respected conservative, indicates that their views represent a solidly entrenched consensus about free speech tenets.

328. Cohen, 403 U.S. at 26 (emphasis added). Professor Tribe eloquently described how Cohen supports a more generous vision of protectible speech than just the intellectually oriented speech that Professor Lawrence would protect: "Justice Harlan's opinion for the majority [in Cohen] implicitly 
Together, Terminiello and Cohen recognize that speech often expresses the speaker's emotions and appeals to the audience's emotions. This generalization applies not only to the ugly words of racist vituperation, but also to the beautiful words of poetry. Indeed, much indisputably valuable language, as well as expressive conduct, has the intention and effect of appealing not directly or not only to the mind. Such language also seeks to and does engage the audience's emotions. If emotionprovoking discourse were denied protected status, then much political speech-which is usually viewed as being at the core of first amendment protection-would fall outside the protected realm. The Court in Terminiello and Cohen rejected the restricted first amendment paradigm of "a sedate assembly of speakers who calmly discussed the issues of the day and became ultimately persuaded by the logic of one of the competing positions." 329 Professor Lawrence reveals his narrower view when he asks, "[A]re racial insults ideas? Do they encourage wide-open debate?"330 In light of the Terminiello-Cohen line of cases, Professor Lawrence wrongly implies that a negative response to these questions should remove racial insults from the domain of protected speech. Professor Lawrence also incorrectly implies that the response to these questions should be negative. Racial insults convey ideas of racial supremacy and inferiority. Objectionable and discredited as these ideas may be, they are ideas nonetheless. ${ }^{331}$

\section{Prohibiting Racist Speech Would Not Effectively COUNTER, AND COULD Even AGgravate, the UNDERLYING PROBLEM OF RACISM}

\section{A. Civil Libertarians Should Continue to Make Combating Racism a Priority}

Despite Professor Lawrence's proffered justifications for regulating a broader spectrum of racist speech, he in fact advocates regulating only a limited category of speech. ${ }^{332}$ Thus, even Professor Lawrence's views of

rejected the hoary dichotomy between reason and desire that so often constricts the reach of the first amendment." L. TRIBE, supra note 58, § 12-1 at 787-88.

329. Rutzick, Offensive Language and the Evolution of First Amendment Protection, 9 HaRv. C.R.-C.L. L. REv. 1,18 (1974). Compare Lawrence, at 452 ("The racial invective is experienced as a blow, not a proffered idea, and . . . it is unlikely that dialogue will follow.").

330. Lawrence, at 463 n.119.

331. Professor Matsuda, supra note 13, at 2360, acknowledged that racist speech conveys an idea when she stated that, "Racial supremacy is one of the ideas we have collectively and internationally considered and rejected." (emphasis added). Professor Lawrence recognized the same point when he quoted this sentence from Matsuda. Lawrence, at 463 n.119.

332. See Lawrence, at $435-36,450$ \& n.82, 458 \& nn.105-06. 
regulable speech, although broader than those of the Supreme Court or traditional civil libertarians, would allow most racist speech on campus.

I do not think it is worth spending a great deal of time debating the fine points of specific rules or their particular applications to achieve what necessarily will be only marginal differences in the amount of racist insults that can be sanctioned. The larger problems of racist attitudes and conduct-of which all these words are symptoms-would remain. Those who share the dual goals of promoting racial equality and protecting free speech must concentrate on countering racial discrimination, rather than on defining the particular narrow subset of racist slurs that constitutionally might be regulable.

I welcome Professor Lawrence's encouragement to civil libertarians to "engage actively in speech and action that resists and counters the racist ideas the first amendment protects." 333 But Professor Lawrence need not urge traditional civil libertarians to "put[ ] at least as much effort and as many resources into fighting for the victims of racism as we put into protecting the rights of racists." 334 The ACLU, for example, puts far more effort and resources into assisting the victims of racism than into defending the rights of racists.

Although ACLU cases involving the $\mathrm{Ku} \mathrm{Klux} \mathrm{Klan}$ and other racist speakers often generate a disproportionate amount of publicity, they constitute only a tiny fraction of the ACLU's caseload. In the recent past, the ACLU has handled about six cases a year advocating the free speech rights of white supremacists, out of a total of more than six thousand cases, ${ }^{335}$ and these white supremacist cases rarely consume significant resources. ${ }^{336}$ Moreover, the resources the ACLU does expend to protect hatemongers' first amendment rights are well-invested. They ultimately preserve not only civil liberties, but also our democratic system, for the benefit of all. ${ }^{337}$

333. Id. at 480 .

334. C. Lawrence, Presentation at ACLU Biennial Conference, see supra note $t$, at 30.

335. Less than one-tenth of one percent of the ACLU's cases involve the defense of groups that might be labeled white supremacists. See ACLU pamphlet, supra note 262, at 10.

336. See A. NEIER, supra note 63, at 148 (free speeeh cases rarely involve factual disputes and therefore can be litigated relatively inexpensively).

337. Aryeh Neier persuasively drew this conclusion with respect to the ACLU's defense of the American Nazi Party's right to demonstrate in Skokie:

[W] hen it was all over no one had been persuaded to join [the Nazis]. They had disseminated their message and it had been rejeeted.

Why did the Nazi message fall on such deaf ears? Revolutionaries and advocates of destruction attract followers readily when the society they wish to overturn loses legitimacy. Understanding this process, revolutionaries try to provoke the government into using repressive measures. They rejoice, as the American Nazis did, when their rights are denied to them; they count on repression to win them sympathizers.

In confronting the Nazis, however, American democracy did not lose, but preserved its legitimacy .... 
The ACLU has devoted substantial resources to the struggle against racism. ${ }^{338}$ The ACLU backed the civil rights movement in its early years, working with lawyers from the National Association for the Advancement of Colored People (NAACP) to plan the attack on segregation. In 1931, the ACLU published Black Justice, a comprehensive report on legalized racism. ${ }^{339}$ Although the ACLU initially was not involved in the infamous Scottsboro cases-in which seven young black men were convicted of raping two white women after sham trials before an all-white jury-an ACLU attorney argued and won the first of these cases to reach the Supreme Court. ${ }^{340}$

During World War II, the ACLU sponsored a challenge to the segregated draft and organized the Committee Against Racial Discrimination. ${ }^{341}$ In the 1950s, the ACLU successfully challenged state laws that made it a crime for a white woman to bear a child she had conceived with a black father. ${ }^{342}$ In the 1960 s, the ACLU provided funds and lawyers to defend civil rights activists, and since then it has lobbied extensively for civil rights legislation. ${ }^{343}$

The ACLU's Voting Rights Project has helped to empower black voters throughout the southern United States, facilitating the election of

The judges who devoted so much attention to the Nazis, the police departments that paid so much overtime, and the American Civil Liberties Union, which lost a half-million dollars in membership income as a consequence of its defense, used their time and money well. They defeated the Nazis by preserving the legitimacy of American democracy.

Id. at $170-71$.

338. This paragraph, and the accompanying footnotes, are drawn substantially from Gale \& Strossen, supra note 19, at 164, 170-71, 175-76.

339. See S. WALKER, supra note 16 , at $88-90$.

340. See id. at 91. See also Powell v. Alabama, 287 U.S. 45, 73 (1932) (conviction reversed because of denial of adequate counsel at trial).

341. See S. WALKER, supra note 16 , at 162-66.

342. See American Civil Liberties Union, ACLU Women's Rights Report (Spring 1980) (available from author).

343. See S. WALKER, supra note 16, at 162-63, 262-70. See also Memorandum from Morton H. Halperin and Wade Henderson to ACLU Executive Committee (Feb. 22, 1990) (available from author). The ACLU's legislative office played a key role in lobbying for such major civil rights legislation as the Fair Housing Amendments Act of 1988, Pub. L. No. 100-430, 102 Stat. 1619 (codified as amended in scattered sections of 28 U.S.C. and 42 U.S.C.), Civil Rights Restoration Act of 1987, Pub. L. No. 100-259, 102 Stat. 28 (codified as amended in scattered sections of 20 U.S.C., 29 U.S.C. and 42 U.S.C.), and renewal of Voting Rights Act Amendments of 1982, Pub. L. No. 97-205, 96 Stat. 131 (codified as amended at 42 U.S.C. $\$ \S 1971$ to $1973 \mathrm{aa}-6$ (1988)); it also took the lead in opposing various constitutional amendments and bills which would have restricted civil rights, including court stripping proposals; during the most recent legislative session it helped to draft and lobbied for numerous pieces of civil rights legislation, including the Racial Justice Act, S. 1696, 101st Cong., 2d Sess. (1990), H.R. 4618, 101st Cong., 2d Sess. (1990), which would prohibit imposition of the death penalty in a racially discriminatory manner, and the Civil Rights Act of 1990, S. 2104, 101st Cong., 2d Sess. (1990), H.R.4000, 101st Cong., 2d Sess. (1990) (veto message read to Senate, , 136 Cong. REC. S16562 (daily ed. Oct. 24, 1990)), which would overturn several recent Supreme Court decisions constricting civil rights remedies. 
hundreds of black officials. ${ }^{344}$ The ACLU also maintains several other special "Projects" whose constituents or clients are predominantly black-for example, the National Prison Project, the Capital Punishment Project, and the Children's Rights Project. For the past several years, the ACLU's national legal department has focused on civil liberties issues related to race and poverty. ${ }^{345}$ In 1988 , ACLU President Norman Dorsen appointed a special commission to oversee and coordinate the national ACLU's multiple efforts to combat racial discrimination. ${ }^{346}$ In addition, state and local-level branches of the ACLU consistently allocate substantial resources to civil rights cases. ${ }^{347}$

As indicated by both policy ${ }^{348}$ and action, the ACLU is committed to eradicating racial discrimination on campus as an essential step toward its larger goal of eliminating racial discrimination from society at large. ${ }^{349}$ For example, ACLU leaders have corresponded and met with university officials to recommend measures that universities could implement to combat campus racism, consistent with both equality and free speech values. ${ }^{350}$ In the same vein, ACLU officials have worked for the implementation of educational programs designed to counter racist attitudes among college students, ${ }^{351}$ as well as younger students. ${ }^{352}$ Addi-

344. See S. WALKER, supra note 16 , at 356-57.

345. See powell, Memorandum, supra note 16.

346. See ACLU Policy Guide, supra note 11, at Policy No. 312b, 389b.

347. For example, the Southern California ACLU (ACLU-SC) successfully challenged school and housing segregation and miscegenation laws as early as 1946. See S. WALKER, supra note 16, at 239. The ACLU-SC initiated and provided lead counsel for the major school desegregation cases in Los Angeles and Pasadena, which spanned more than two decades. See the cases that culminated in Crawford v. Board of Educ., 458 U.S. 527 (1982); Pasadena City Bd. of Educ. v. Spangler, 427 U.S. 424 (1976); Jackson v. Pasadena City School Dist., 59 Cal. 2d 876, 382 P.2d 878, 31 Cal. Rptr. 606 (1963).

348. See supra note 11 and Appendix.

349. See supra note 15.

350. See, e.g., Rowan, "Apartheid" on U.S. Campuses, North America Syndicate, Press Release (June 28, 1989) (describes such proposals made by Ira Glasser, ACLU Executive Director); Letter from Ira Glasser to university presidents (July 12, 1989) (available from author).

351. See generally responses to survey of ACLU affiliates regarding efforts to promote diversity (June 15, 1990) [hereinafter ACLU Survey] (available from author). The following responses are of particular interest: Response of Massachusetts affiliate, at 3 (offering programs for dealing with racism on university campuses); Response of New Hampshire affiliate, at 3 (planning forum on campus hate speech and racism); Response of North Carolina affiliate, at 3 (seeking funding for project to counter underlying causes of campus hate speech); Response of Northern California affiliate, at 4 (working in coalition to develop program to educate undergraduates about value of affirmative action).

352. See, e.g., ACLU Survey, supra note 351, Response of Arkansas affiliate, at 3 (working with coalition on developing programs for reducing racial tensions in high schools); Response of Colorado affiliate, at 3 (worked closely with minority groups to deal with racial incidents in schools); Response of Kentucky affiliate, at 3 (organized community and expert testimony on racism in public schools); Response of Massachusetts affiliate, at 3 (developed programs on racism for schools, held studentteacher conference on racism, and conducted summer institute for teachers on racism); Response of 
tionally, ACLU representatives have participated in universities' deliberations about whether to adopt anti-hate-speech rules, and if so, how to frame them. ${ }^{353}$ Representatives of the ACLU also have organized investigations of racist incidents at specific campuses, for purposes of advising university officials how to counter those problems. ${ }^{354}$ Furthermore, ACLU officials have organized and participated in protests of racist incidents, both on campus and more generally. ${ }^{355}$

In light of these efforts, Professor Lawrence's suggestion that "the call for fighting racist attitudes and practices rather than speech [is] 'just a lot of cheap talk' "356 is a cheap shot. In particular, it is noteworthy that the ACLU affiliates that have brought lawsuits challenging campus hate speech regulations also have undertaken specific efforts to counter

New York affiliate, at 3 (NYCLU official designed and co-teaches course at public high school about roots of racism and has trained other bi-racial teams to teach this course at other high schools throughout New York City); Response of Oregon affiliate, at 3 (working with Portland School District officials to include study of racism in curriculum). See also Goodstein, Warding Off Intolerance in a Brooklyn School, Wash. Post, Apr. 10, 1990, at A.3, col. 1 (describes ACLU program to teach about racism in public schools).

353. See, e.g., Mayers, ACLU May Ask Court to Halt UW's Anti-Racism Proposal, Wisconsin State J., July 11, 1989, Bl, col. 1 (Wisconsin ACLU affiliate recommended specific changes to proposed rules and said that if changes were adopted, ACLU would not make facial challenge to them, but rather "would wait and see how the rules are working"); Michigan Regents' Minutes, supra note 203, at 19 (March 17, 1988) (at public hearing on proposed regulations, Michigan ACLU affiliate supported concept of discriminatory harassment policy but made suggestions for improving specific proposal); see also Appendix to Judgment, Wu v. University of Conn., No. Civ. H-89-649 PCD (D. Conn. Jan. 25, 1990) (Conneeticut ACLU affiliate recommended specific language that was substituted for University of Connecticut's anti-hate-speech rule, pursuant to agreement settling lawsuit).

354. See, e.g., ACLU Survey, supra note 351, Response of Wisconsin affiliate, at 3 (ACLU Wisconsin affliate worked in coalition with black student organizations and other minority organizations for purposes of conducting state-wide investigation of racism on campus, including through use of public hearings, and making recommendations of appropriate responses to campus officials). Compare Lawrence, at 478 ("In the view of minority delegates [to the 1989 ACLU Biennial Conference], hearings should be held on university campuses where the incidence and nature of the injury of racist speech could be carefully documented and responses that were least restrictive of protected speech could be recommended. ... But this approach ... was rejected.").

355. For recent examples, see, e.g., Smothers, New Coalition Condemns Howard Beach Assaults, N.Y. Times, Dec. 24, 1986, at B4, col. 2. Smothers wrote that:

The executive director of the New York Civil Liberties Union, Norman Siegel, an organizer of the New Civil Rights coalition, said it was a multi-racial effort to "let everyone know unequivocally that we will not tolerate incidents of racial bigotry or a climate that fosters anything but racial equality and harmony in our city."

See also ACLU Survey, supra note 351, Response of New Jersey affiliate, at 3 (co-sponsored March Against Racism in Newark during spring of 1990); Response of New York affiliate, at 3 (as cofounder of New York City Civil Rights Coalition, affiliate has organized and participated in marches and rallies against racism). In contrast, Lawrence argues without citing sources that "[t]hose who raise their voices in protest against public sanctions of racist speech have not organized private protests against the voices of racism. ... [T]raditional civil libertarians have been conspicuous largely in their absence from ... group expressions of condemnation [of racism]." Lawrence, at 47677.

356. Lawrence, at 480 n. 166 . 
campus and societal racism. 357 Moreover, the charge of "cheap talk" more appropriately might be leveled at those who focus their attention on hate speech regulations. Such regulations may appear to provide a relatively inexpensive "quick fix," but racist speech is only one symptom of the pervasive problem of racism, and this underlying problem will not be solved by banming one of its symptoms.

\section{B. Punishing Racist Speech Would Not Effectively Counter Racism}

Parts II and III of this Article emphasized the principled reasons, arising from first amendment theory, for concluding that racist speech should receive the same protection as other offensive speech. This conclusion also is supported by pragmatic or strategic considerations concerning the efficacious pursuit of equality goals. Not only would rules censoring racist speech fail to reduce racial bias, but they might even undermine that goal.

First, there is no persuasive psychological evidence that punishment for name-calling changes deeply held attitudes. To the contrary, psychological studies show that censored speech becomes more appealing and persuasive to inany listeners inerely by virtue of the censorship. ${ }^{358}$

Nor is there any einpirical evidence, from the countries that do outlaw racist speech, that censorship is an effective means to counter racism. For example, Great Britain began to prohibit racist defamation in

357. The three affiliates that have challenged university hate speech rules are located in Connecticut, Michigan, and Wisconsin. See supra note 17. All three are engaged in ongoing efforts to counter race discrimination. See ACLU Survey, supra note 351, Response of Connecticut affiliate, at 3 (it is currently producing videotape and teacher's guide, dealing with equality, for secondary school teachers, for statewide distribution free or at a nominal charge; it also is initiating the development and institution of curriculum on bigotry for elementary schools statewide); Response of Michigan affiliate, at Attachment $C$ (summarizes recent and upcoming litigation, legislative program, and public edueation efforts regarding racial discrimination and prejudice); $i d$. at Attachment C (it won favorable settlement in case brought on behalf of two black University of Michigan gradu* ate students who were asked to leave an all-white suburb where they were conducting research); Response of Wisconsin affiliate, at 3 (it organized and is working with coalition of civil rights groups to investigate and recommend University's response to campus racial incidents); id. at Appendix ("In March, 1988, the [Wisconsin affiliate] decided to devote the majority of the organization's resources to proteeting the civil rights of racial minorities and the poor."); id. at Appendix (summarizes current activities of affiliate's "Poverty, Race and Civil Liberties Project").

Compare Lawrenee, at 480 ("When the ACLU enters the debate by challenging the University of Michigan's efforts to provide a safe harbor for its [minority] students . . . , we should not be surprised that non-white students feel abandoned.").

358. See Brock, Erotic Materials: A Commodity Theory Analysis of Availability and Desirability, in 1 TEChNICAL REPORT OF THE U.S. COMM'N ON OBSCENITY \& PORNOGRAPHY 131, 132 (1971); Tannenbaum, Emotional Arousal As a Mediator of Communication Effects, in 8 TECHNICAL REPORT OF THE U.S. COMM'N ON OBSCENITY \& PoRNOGRAPhy 326-56 (1971); Worchel \& Arnold, The Effects of Censorship and Attractiveness of the Censor on Attitudinal Change, 9 J. EXPERIMENTAL Soc. Psychology 365 (1973). 
1965. ${ }^{359}$ A quarter century later, this law has had no discernible adverse impact on the National Front and other neo-Nazi groups active in Britain. ${ }^{360}$ As discussed above, ${ }^{361}$ it is impossible to draw narrow regulations that precisely specify the particular words and contexts that should lead to sanctions. Fact-bound deterninations are required. For this reason, authorities have great discretion in deternining precisely which speakers and which words to punish. Consequently, even vicious racist epithets have gone unpunished under the British law. ${ }^{362}$ Moreover, even if actual or threatened enforcement of the law has deterred some overt racist insults, that enforceinent has had no effect on more subtle, but nevertheless clear, signals of racism. ${ }^{363}$ Some observers believe that racism is even inore pervasive in Britain than im the Uinted States. ${ }^{364}$

\section{Banning Racist Speech Could Aggravate Racism}

For several reasons banning the symptom of racist speech inay compound the underlying problem of racism. Professor Lawrence sets up a false dichotomy when he urges us to balance equality goals against free speech goals. Just as he observes that free speech concerns should be weighed on the pro-regulation, as well as the anti-regulation, side of the balance, ${ }^{365}$ he should recoguize that equality concerns weigh on the antiregulation, as well as the pro-regulation, side. ${ }^{366}$

359. See infra text accompanying notes $367-70$ for discussion of the Race Relations Act, 1965, ch. 73.

360. See A. NeIER, supra note 63 , at 15455 .

361. See supra text accompanying notes 218-21.

362. See Lasson, Racism in Great Britain: Drawing the Line on Free Speech, 7 B.C. THIRD WORLD L.J. 161, 166, 171-73 (1987) (Democratic National Party Chairman Kingsley Read was tried under Race Relations Act in 1978 for referring in a public speech to "niggers, wogs, and coons," and for commenting on an Asian who had been killed in a race riot, "One down, a million to go." The judge instructed the jury that Read's words were not in themselves unlawful, and the jury acquitted Read.).

363. See id. (in response to anti-hate speech laws, contemporary racist publications tend to be more cautiously worded). See also A. NEIER, supra note 63, at 155 (National Front speakers substitute code words, such as attacks on immigration and calls for law and order, for explicit racist references).

364. For example, a 1988 article in the New York Times discussed the many incidents of violence against blacks and Asians in London and quoted Paul Boateng, one of the four minority members of the 650-member House of Commons, as follows:

[This] violence is linked to the deeper patterns of prejudice in a society in which racist behavior is more socially acceptable than in the United States.... We should not underestimate the degree to which greed and racism have become legitimate in Britain .... [T]he basic difference between the United States and Britain is that no one in America questions the concept of the black American. In Britain we still have not won the argument of whether it is possible to be black and British.

Raines, London Police Faulted as Racial Attacks Soar, N.Y. Times, Mar. 24, 1988, at A1, col. 1.

365. See Lawrence, at 458.

366. In a passage cited by Professor Lawrence, see id. at 446 n.66, Professor Michelman recognizes this point with respect to the analogous debate over whether pormography should be regulated. 
The first reason that laws censoring racist speech may undermine the goal of combating racism flows from the discretion such laws inevitably vest in prosecutors, judges, and the other individuals who implement them. One ironic, even tragic, result of this discretion is that members of minority groups themselves-the very people whom the law is intended to protect-are hikely targets of punishment. For example, among the first individuals prosecuted under the British Race Relations Act of $1965^{367}$ were black power leaders. ${ }^{368}$ Their overtly racist messages undoubtedly expressed legitimate anger at real discrimination, yet the statute drew no such fine lines, nor could any similar statute possibly do so. Rather than curbing speech offensive to minorities, this British law instead has been regularly used to curb the speech of blacks, trade unionists, and anti-nuclear activists. ${ }^{369}$ In perhaps the ultimate irony, this statute, which was intended to restrain the neo-Nazi National Front, instead has barred expression by the Anti-Nazi League. ${ }^{370}$

The British experience is not unique. History teaches us that antihate speech laws regularly have been used to oppress racial and other minorities. For example, none of the anti-Semites who were responsible for arousing France against Captain Alfred Dreyfus were ever prosecuted for group libel. But Emile Zola was prosecuted for libeling the French clergy and military in his "J'Accuse," and he had to fiee to England to escape punishment. ${ }^{371}$ Additionally, closer to home, the very doctrines that Professor Lawrence invokes to justify regulating campus hate speech-for example, the fighting words doctrine, upon which he

See Michelman, Conceptions of Democracy in American Constitutional Argument: The Case of Pornography Regulations, 56 TENN. L. REv. 291, 307 (1989) (state should weigh "the infringements of liberty and equal protection" that would result from regulating pornography against "the infringements of liberty and equal protection" that would result from non-regulation) (emphasis added). See also infra note 396 (feminists have argued that regulating pornography would violate equal protection clause and discriminate against women).

367. In 1965, Parliament adopted the Race Relations Act, 1965, ch. 73, which criminalized the intentional incitement of racial hatred. The Act was amended in 1976 to eliminate the intent requirement of proving intent. The amended law made it an offense to distribute literature or to use words likely to stir up hatred against any racial group. In 1986, Parliament enacted the Public Order Act, 1986, ch. 64, which was designed to further ease the prosecution's evidentiary burden in proving incitement to racial hatred. It criminalizes conduct which is either likely or intended to "stir up" racial hatred. See Lasson, supra note 362, at 166, 171-73.

368. See Lasson, supra note 362, at 169.

369. See A. NeIER, supra note 63 , at $153-55$.

370. See id. at 157.

371. See ACLU pamphlet, supra note 262, at 8-9. See also Stein, History Against Free Speech: The New German Law Against the "Auschwitz"-and Other- "Lies," 85 MrCH. L. Rev. 277 (1986). Stein argues that although there was an article in the German Criminal Code in 1871 that punished offenses against personal honor,

[T]he German Supreme Court . . . consistently refused to apply this article to insults against Jews as a group-although it gave the benefit of its protection to such groups as 
chiefly relies-are particularly threatening to the speech of racial and political mimorities. 372

The general lesson that rules banning hate speech will be used to punish minority group members has proven true in the specific context of campus hate speech regulations. In 1974, in a move aimed at the National Front, the British National Union of Students (NUS) adopted a resolution that representatives of "openly racist and fascist organizations" were to be prevented from speaking on college campuses "by whatever means necessary (including disruption of the meeting)." $373 \mathrm{~A}$ substantial motivation for the rule had been to stem an increase in campus anti-Semitism. Ironically, however, following the United Nations' cue, ${ }^{374}$ some British students deemed Zionism a form of racism beyond the bounds of permitted discussion. Accordingly, in 1975 British students invoked the NUS resolution to disrupt speeches by Israelis and Zionists, including the Israeli ambassador to England. The intended target of the NUS resolution, the National Front, applauded this result. However, the NUS itself became disenchanted by this and other unintended consequences of its resolution and repealed it in 1977.375

The British experience under its campus anti-hate speech rule parallels the experience in the United States under the one such rule that has led to a judicial decision. During the approximately one year that the University of Michigan rule was in effect, there were more than twenty cases of whites charging blacks with racist speech. ${ }^{376}$ More importantly, the only two instances in which the rule was invoked to sanction racist speech (as opposed to sexist and other forms of hate speech) involved the punishment of speech by or on behalf of black students. ${ }^{377}$ Additionally, the only student who was subjected to a full-fledged disciplinary hearing

\footnotetext{
"Germans living in Prussian provinces, large landowners, all Christian clerics, German officers, and Prussian troops who fought in Belgium and Northern France."

Id. at 286 (quoting P. Paepcke, Antisemitismus und Strafrecht 164 (dissertation, Albert-LudwigsUniversität Freiburg i. Br., 1962)) (footnotes omitted).

372. See supra text accompanying notes $137-46$ (fighting words), $52-53$ (intentional infliction of emotional distress) \& 174-75 (group defamation).

373. A. NEIER, supra note 63 , at $155-56$.

374. See G.A. Res. 3379, U.N. GAOR Supp. (No. 34) at 83, U.N. Doc. A/10034 (1975).

375. See Neier, supra note 63 , at 156 . Some conservatives who were "very far from being Fascists" also were barred from speaking under the NUS resolution. Id.

376. See Gottlieb, supra note 4.

377. See Plaintiff's Exhibit Submitted in Support of Motion for Preliminary Injunction at 1, Doc v. University of Mich., 721 F. Supp. 852 (E.D. Mich. 1989) (No. 89-CV-71683-DT) (black student used term "white trash" in conversation with white student); id. at 5 (at beginning of preclinical dentistry course, recognized as difficult, faculty member led small group discussion, designed to "identify concerns of students"; dental student said that he had heard, from his minority roommate, that minorities have a difficult time in the course and were not treated fairly; the faculty member, who was black, complained that the student was accusing her of racism).
} 
under the Michigan rule was a black student accused of homophobic and sexist expression. ${ }^{378}$ In seeking clemency from the sanctions imposed following this hearing, the student asserted he had been singled out because of his race and his pohtical views. ${ }^{379}$ Others who were punished for hate speech under the Michigan rule included several Jewish students accused of engaging in anti-Semitic expression ${ }^{380}$ and an Asian-American student accused of making an anti-black comment. ${ }^{381}$ Likewise, the student who recently brought a lawsuit challenging the University of Connecticut's hate speech policy, under which she had been penalized for an allegedly homophobic remark, was Asian-American. ${ }^{382}$ She claimed that, among the other students who had engaged in similar expression, she had been singled out for punishment because of her ethnic background. ${ }^{383}$

Professor Lawrence himself recognizes that rules regulating racist speech might backfire and be invoked disproportionately against blacks and other traditionally oppressed groups. Indeed, he charges that other university rules already are used to silence anti-racist, but not racist, speakers. ${ }^{384}$ Professor Lawrence proposes to avoid this danger by excluding from the rule's protection "persons who were vilified on the basis of their membership in dominant majority groups." 385 Even putting aside the fatal first amendment flaws in such a radical departure from

378. See id. at 6 (social work student was charged with saying in class that homosexuality is an illness that needs to be cured and that he had developed a model to move gay men and lesbians toward a heterosexual orientation; he also was charged with sexual harassment against particular women).

379. See letter to James J. Duderstadt, President, University of Michigan, from a student (whose name and signature were deleted from the copy produced during litigation, to protect the student's privacy) (May 23, 1989), reprinted in Plaintif's Exhibit Submitted in Support of Motion for Preliminary Injunction, Doe, 721 F. Supp. at 852 . The student claimed that:

[T] he charges were pretexual [sic] and a coverup for vindictiveness based on my refusal to support any radical movements. ... Moreover, these few students knew that a black student would have no chance of wining [sic] a favorable decision against such charges. These charges will haunt me for the rest of my life. ... [T] [hey will be used against me to prevent me from becoming a certified Social Worker ....

380. See id. at 1-2 (students wrote graffiti, including swastika, on classroom blackboard, and said they intended it as a practical joke).

381. See id. at 2-3 (his allegedly offensive remark was the question why black people feel discriminated against; after being charged, he explained that he was attempting to complain that black students in his dormitory tended to socialize together, with the result that he felt socially isolated).

382. See Wu v. University of Conn. (No. Civ. H89-649 PCD) (D. Conn. 1989); see also Black Talks Prompt Protest and Complaint, N.Y. Times, Dec. 10, 1989, $\S 1$, at 67, col. 1 (first complaint filed under Trinity College's new racial harassment policy was against black speaker sponsored by black student organization, Black-Power Serves Itself).

383. Letter from Martin Margulies, of Connecticut Civil Liberties Union, to author, at 5 (Jan. 23, 1990) (available from author).

384. See Lawrence, at 466 (noting "cruel irony" in Stanford's refusal to punish white students for hanging racist poster in dormitory, while punishing black students who engaged in peaceful sit-in to protest that refusal).

385. Id. at $450 \mathrm{n} .82$. 
content- and viewpoint-neutrality principles, ${ }^{386}$ the proposed exception would create far more problems of equality and enforceability than it would solve. ${ }^{387}$

A second reason why censorship of racist speech actually may subvert, rather than promote, the goal of eradicating racism is that such censorship measures often have the effect of glorifying racist speakers. Efforts at suppression result in racist speakers receiving attention and publicity which they otherwise would not have garnered. As previously noted, psychological studies reveal that whenever the government attempts to censor speech, the censored speech-for that very reasonbecomes more appealing to many people. ${ }^{388}$ Still worse, when pitted against the government, racist speakers may appear as martyrs or even heroes.

Advocates of hate speech regulations do not seem to realize that their own attempts to suppress speech increase public interest in the ideas they are trying to stamp out. Thus, Professor Lawrence wrongly suggests that the ACLU's defense of hatemongers' free speech rights "makes heroes out of bigots"; ${ }^{389}$ in actuality, experience demonstrates that it is the attempt to suppress racist speech that has this effect, not the attempt to protect such speech. ${ }^{390}$

There is a third reason why laws that proscribe racist speech could well undermine goals of reducing bigotry. As Professor Lawrence recog-

386. See supra text accompanying notes 105-14.

387. Just one such problem is how "dominant majority groups" would be defined. Would they be defined in the context of the particular academic community-for example, at Howard Law School, blacks would probably fit this definition, and at Cardozo Law School, Jews would-or in the context of the larger society?

This definitional problem is compounded by the fact that Professor Lawrence would require a ranking of the relative dominance or subordination of various groups. During an oral defense of this proposal, at Duke University School of Law on January 27, 1990, Professor Lawrence "clarified" that it would prohibit a white woman from disparaging a black or gay man, but not a white, heterosexual man. Professor Lawrence did not explain whether these outcomes would differ if the female speaker were lesbian. See also Cohen, On Harassment, ACADEmic Questions, Spring 1990, at 23, 29 (criticizing proposition that campus hate speech regulations should be applied differentially to various groups, depending on their societal status). Cohen stated that:

Even if there were moral and intellectual substance to the distinction between subordinate and nonsubordinate groups, the theoretical and operational barriers to determining the membership and privileges of these groups secm insurmountable. The better rule is for the university to remain agnostic, and trcat all its members as individuals and equals.

388. See supra note 358 and accompanying text.

389. Lawrence, at 438 ; accord id. at 436,480 .

390. For example, when the American Nazi Party finally was allowed to march in lllinois in 1978, following the government's and Anti-Defamation League's attempts to prevent this demonstration, 2000 onlookers watched the 20 Nazis demonstrate. See A. NEIER, supra note 63, at 169. And throughout the protracted litigation that the Nazis predictably won, the case received extensive media attention all over the country. See id. at 8 . The event probably would have received little if any attention had the Village of Skokie simply allowed the Nazis to demonstrate in the first place. 
nizes, given the overriding importance of free speech in our society, any speech regulation must be narrowly drafted. ${ }^{391}$ Therefore, it can affect only the most blatant, crudest forms of racism. The more subtle, and hence potentially more invidious, racist expressions will survive. Virtually all would agree that no law could possibly eliminate all racist speech, let alone racism itself. If the marketplace of ideas cannot be trusted to winnow out the hateful, then there is no reason to believe that censorship will do so. The most it could possibly achieve would be to drive some racist thought and expression underground, where it would be more diffcult to respond to such speech and the underlying attitudes it expresses. ${ }^{392}$ The British experience confirms this prediction. ${ }^{393}$

The positive effect of racist speech-in terms of making society aware of and mobilizing its opposition to the evils of racism-are illustrated by the wave of campus racist incidents now under discussion. Ugly and abominable as these expressions are, they undoubtedly have had the beneficial result of raising public consciousness about the underlying societal problem of racism. If these expressions had been chilled by virtue of university sanctions, then it is doubtful that there would be such widespread discussion on campuses, let alone more generally, about the real problem of racism. ${ }^{394}$ Consequently, society would be less mobilized to attack this problem. Past experience confirms that the public airing of racist and other forms of hate speech catalyzes communal efforts to redress the bigotry that underlies such expression and to stave off any discriminatory conduct that might follow from it. ${ }^{395}$

391. See Lawrence, at 435,450 n. $82,458 \&$ n.105, 481.

392. See A. NeIER, supra note 63, at 158 (noting that, in British context, it is far more dangerous when a major party such as the Conservative Party engages in racist politics, even though it uses polite language, than when a minor party attracts attention through ugly racist epithets).

393. See supra text accompanying notes $367-75$. See also Lasson, supra note 362 , at 170 . The Lasson article stated that:

[A] major effcct of [the British anti-hate-speech] act has been to leave certain organizations with but two choices: to restrict their circulation to the members of a specific club, or to be more careful in their language. However, although this seems a positive development, it is possible that provocatively racist messages, by being concealed in genteel, and outwardly acceptable language, could be disseminated to an even larger number of people-thereby promoting more racial ill-will rather than decreasing such feelings.

394. See infra notes $404-07$ and accompanying text.

395. See S. WALKER, supra note 16, at 59-62 (the ACLU's content-neutral defense of free speech permitted the Ku Klux Klan — which in the 1920 s dominated many state legislatures, played a major role at the 1924 national Democratic convention, and staged a massive march on Washington, D.C.-to diminish its own influence by exposing its vicious plans to public view). See also A. NEIER, supra note 63, at 34 . Neier stated that:

The Nazis deter the expression of anti-Semiţism in forms that might be more palatable to the American public and, therefore, more threatening to the Jews. Other anti-Semites must impose restraints on themselves for fear of being bracketed with the almost univer- 
Banning racist speech could undermine the goal of combating racism for additional reasons. Some black scholars and activists maintain that an anti-racist speech policy may perpetuate a paternalistic view of minority groups, suggesting that they are incapable of defending themselves against biased expressions. ${ }^{396}$ Additionally, an anti-hate speech policy stultifies the candid intergroup dialogue concerning racism and other forms of bias that constitutes an essential precondition for reducing discrimination. In a related vein, education, free discussion, and the airing of misunderstandings and failures of sensitivity are more likely to promote positive intergroup relations than are legal battles. The rules barring hate speech will continue to generate litigation and other forms of controversy that will exacerbate intergroup tensions. Finally, the censorship approach is diversionary. It makes it easier for communities to avoid coming to grips with less convenient and more expensive, but ultimately more meaningful, approaches for combating racial discrimination.

sally hated Nazis. A strong Nazi movement would be a great danger to Jews in the United States; a weak Nazi movement with no potential for growth has its uses.

Similarly, the speech of anti-pornography feminists has had a discernible impact on public perceptions, as well as public policy, concerning the connection between gender discrimination and pornography. If the censorship strategy had driven anti-female pornography from public view, this impact may well have been lessened. For example, a major public education and lobbying tool employed by Women Against Pornography is the display of anti-female pornographic images. 1ronically, such displays would be prohibited under censorship legislation proposed by some feminist pornography opponents. See supra notes $228-30$ and aceompanying text.

396. See, e.g., supra text accompanying note 5 (quote from Alan Keyes criticizing the Stanford code); see also supra text aceompanying note 10 (quote from Michael Meyers).

Similarly, while some feminists have advocated the regulation of pornography, arguing that regulation would promote women's equality, see, e.g., A. DWORKIN, PORNOGRAPHY: MEN PosSESSING WOMEN (1981), other feminists have argued that regulation would hinder that goal. See, e.g., Hunter \& Law, Brief Amici Curiae of Feminist Anti-Censorship Taskforce, et al., in American Booksellers Association v. Hudnut, 21 U. MICH. J.L. REF. 69 (1988) (arguing that anti-pornography ordinance suppresses constitutionally protected speech in a manner particularly detrimental to women, and unconstitutionally discriminates on the basis of sex and reinforces sexist stereotypes). The arguments made by this latter group of feminists appear in large part applicable to regulations of racist speech, as well. See, e.g., id. at 122. Hunter and Law stated that:

The [Indianapolis] ordinance presumes women as a class (and only women) are subordinated by virtually any sexually explicit image. . . .

Such assumptions reinforce and perpetuate central sexist stereotypes; they weaken, rather than enhance, women's struggles to free themselves of archaic notions of gender roles. ... In treating women as a special class, [this ordinance] repeats the"error of earlier protectionist legislation. which gave women no significant benefits and denied their equality. 


\section{Means Consistent With the First Amendment Can Promote Racial Equality More Effectively Than CAN CENSORSHIP}

The Supreme Court recently reaffirmed the time-honored principle that the appropriate response to speech conveying ideas that we reject or find offensive is not to censor such speech, but rather to exercise our own speech rights. In Texas v. Johnson, ${ }^{397}$ the Court urged this counterspeech strategy upon the many Americans who are deeply offended by the burning of their country's flag: "The way to preserve the flag's special role is not to punish those who feel differently about these matters. It is to persuade them that they are wrong." 398 In addition to persuasion, the types of private expressive conduct that could be invoked in response to racist speech include censure and boycotts. ${ }^{399}$

In the context of countering racism on campus, the strategy of increasing speech-rather than decreasing it-not only would be consistent with first amendment principles, but also would be more effective in advancing equahity goals. All governinent agencies and officers, including state university officials, should condemn slavery, de jure segregation, and other racist institutions that the government formerly supported. State university and other governinent officials also should affirmatively endorse equality principles. Furthermore, these governinent representatives should condemn racist ideas expressed by private speakers. ${ }^{400}$ In the same vein, private individuals and groups should exercise their first ainendment rights by speaking out against racism. Traditional civil libertarians have exercised their own speech rights in this fashion ${ }^{401}$ and also

397. 109 S. Ct. 2533 (1989).

398. Id. at 2567.

399. See Matsuda, supra note 13, at 2358 n.201 (cites recent exchanges among American-Arab Anti-Discrimination Committee, B'nai B'rith International, and other organizations which effectively remedied ethnically derogatory expressions).

400. See Bok, supra note 6, at 6 . In response to a letter demeaning women that a student club had circulated, Derek Bok, President of Harvard University, argued that this letter should not be suppressed. He then issued the following public criticism of the letter:

The wording of the letter was so extreme and derogatory to women that I wanted to communieate my disapproval publicly, if only to make sure that no one could gain the false impression that the Harvard administration harbored any sympathy or complacency toward the tone and substance of the letter. Such action does not infringe on free speech. Indeed, statements of disagreement are part and parcel of the open debate that freedom of speech is meant to encourage; the right to condemn a point of view is as protected as the right to express it. Of course, I recognize that even verbal disapproval by persons in positions of authority may have inhibiting effeets on students. Nevertheless, this possibility is not sufficient to outweigh the need for officials to speak out on matters of significance to the community-provided, of course, that they take no action to penalize the speech of others.

401. For recent examples, see supra note 355. In contrast, Lawrence claims, without support, that "[t]hose who raise their voices in protest against public sanctions of racist speech have not organized private protests against the voices of racism. ... Traditional civil libertarians have been 
have defended the first amendment freedoms of others who have done so. ${ }^{402}$

In addition to the preceding measures, which could be implemented on a society-wide basis, other measures would be especially suited to the academic setting. First, regardless of the legal limitations on rules barring hate speech, universities should encourage members of their communities voluntarily to restrain the form of their expression in light of the feelings and concerns of various mmority groups. ${ }^{403}$ Universities could facilitate voluntary self-restraint by providing training in communications, information about diverse cultural perspectives, and other education designed to promote intergroup understanding. Members of both minority and majority groups should be encouraged to be mutually respectful. Individuals who violate these norms of civility should not be subject to any disciplinary action, but instead should be counseled. ${ }^{404}$ These educational efforts should be extended to members of the faculty and administration, as well as students. Of course, universities must vigilantly ensure that even voluntary limits on the manner of academic discourse do not chill its content.

conspicuous largely in their absence from . . group expressions of condemnation [of racism]." Lawrence, at 476-77.

402. See, e.g., A. NEIER, supra note 63, at 170 (Illinois ACLU, which had represented neo-Nazi group seeking to demonstrate, also assisted anti-Nazi groups in securing their first amendment rights to counter-demonstrate). Professor Lawrence asserts, without supporting authorities, that "[w]hen racial minorities or other victims of hate speech hold counter-demonstrations . . . civil libertarians often accuse them of private censorship, of seeking to silence opposing points of view." Lawrence, at 477. This unsubstantiated generalization is at odds with the relevant ACLU policy, which protects "[h]eckling or any other interruption of a speaker, as a form of speech or expression," unless it is so "extreme ... that [it] effectively prevents the speaker from speaking or the audience from hearing." ACLU Policy Guide, supra note 11, at Policy No. 44.

It should be noted that the above-quoted policy is yet another example, see supra text accompanying notes 52-77, of the ACLU's rccognition that expressive conduct should not be deemed absolutely protected by the first amendment just because it is verbal in form. See id. (counterspeech that effectively prevents speaker from speaking or audience from hearing "cannot be classified as protected speech even though it is verbal in form. It has the same effect, in preventing communication, as acts of physical force.").

403. See University of Texas Report, supra note 115, at 4. The Report admonishes students and faculty that:

[W] hatever the legal boundaries of free speech, the members of an educational community should voluntarily adopt standards of civility and good taste that refiect mutual respect, understanding, and sensitivity among its diverse racial, ethnic, and cultural groups. In particular, members of the faculty represent The University and have a special role and position of authority with respect to students. They should treat students with respect and should be sensitive to the impact of their words and opinions on them.

404. See, e.g., Report of Annenberg Workshop, supra note 156, at 2. The Annenberg Workshop concluded that:

[M]any ... [incidents of derogatory communicative behavior on campus] are so entwined with the expression of political, religious or social points of view that they should not trigger any disciplinary response at all, or are in a sufficiently gray area ... that the response of an educational institution should be counselling rather than punishment .... 
In addition to the foregoing measures, universities also should create forums in which controversial race-related issues and ideas could be discussed in a candid but constructive way. Another possibility would be for universities to encourage students to receive education in the history of racism and the civil rights movement in the United States and an exposure to the culture and traditions of racial and ethnic groups other than their own. Consistent with free speech tenets, these courses must allow all faculty and students to express their own views and must not degenerate into "reeducation camps." 405

The proposed measures for eliminating racism on campus are consistent not only with American constitutional norms of free speech and equality, but also with internationally recognized human rights. For example, the Universal Declaration of Human Rights provides that individuals have a right to receive, and states have an obligation to provide, education which "promote[s] understanding, tolerance and friendship among all nations, racial or religious groups."406

If universities adopt narrowly framed rules that regulate racist expression, then these rules should constitute one element of a broader program that includes the more positive, direct strategies outlined above. Many universities appear to be responding constructively to the recent upsurge in campus hate speech incidents by adopting some of the measures suggested here. ${ }^{407}$ This development demonstrates the positive impact of racist speech, in terms of galvanizing community efforts to counter the underlying attitudes it expresses.

405. See generally Strossen, "Secular Humanism" and "Scientific Creationism": Proposed Standards for Reviewing Curricular Decisions Affecting Students' Religious Freedom, 47 Oн1о ST. L.J. 333, 383 (1986) (listing characteristics of a non-indoctrinating mode of instruction).

406. Universal Declaration, supra note 258, at art. 26(2). Accord art. 13(1), International Covenant on Economic, Social, and Cultural Rights.

407. See, e.g., Carnegie Found. Special Report, supra note 7, at 32 ("The University of Minnesota requires that all students take at least two courses on different American cultures. Mt. Holyoke and Tufts University have a similar requirement. The University of California, Berkeley, Faculty Senate recently ruled that all undergraduates must take at least one course in American Cultures."). The University of Texas Report, supra note 115, at 23-25, in addition to recommending a rule that punishes certain racist expressions, see supra note 152, recommends that the University of Texas take the following additional steps to promote intergroup relations: orientation for all new students should include sensitivity sessions to reduce misunderstanding among different cultural groups; student extracurricular programs on multiculturalism should be expanded; all faculty, as well as other university employees, should participate in seminars about how to exercise their responsibilities in a multicultural academic setting; degree programs should require courses that foster an understanding of the responsibilities of living in a multicultural community, nation, and world; the entire curriculum should be reexamined from this perspective, and the form and content of particular courses should be restructured where necessary; consideration should be given to including required courses that deal with the social sciences and the arts with respect to people of different cultural backgrounds. 
It is particularly important to devise anti-racism strategies consistent with the first amendment because racial and other minority groups ultimately have far more to lose than to gain through a weakened free speech guarantee. History has demonstrated that minorities have been among the chief beneficiaries of a vigorous free speech safeguard. ${ }^{408}$

Professor Lawrence offers two rebuttals to the proposition that blacks are (on balance) benefited rather than hurt by a strong free speech guarantee. First, he notes that "[t]he first amendment coexisted with slavery." 409 It is undeniable that, until the Union won the Civil War, not only the first amendment, but also all of the Constitution's provisions guaranteeing liberty, coexisted with the total negation of liberty through the institution of slavery. It also is true, however, that the free speech guarantees of the federal Constitution and some state constitutions allowed abolitionists to advocate the end of slavery. ${ }^{410}$ Moreover, it must be recalled that until the 1930 s, the first amendment provided no protection whatsoever against speech or press restrictions enacted by state or local governments. ${ }^{411}$ Further, although the first amendment from its adoption provided theoretical protection against actions by the national government, in practice it was not enforced judicially until the latter half of the 20th century. Not until 1965 did the Supreme Court initially exercise its power-which it had recognized 162 years earlier ${ }^{412}$ - to invalidate unconstitutional congressional statutes in the first amendment

408. See A. NEIER, supra note 63, at 5-7. Neier stated that:

It is a matter of self-interest. The oppressed are the victims of power. If they are to end their oppression, they must either win freedom or take power themselves. ...

Jews and friends of Jews may hold power in Skokie, but they do not hold power in the rest of the country. Nor will they ever. The Jews in Skokie require restraints on power to guard themselves. Keeping a few Nazis off the streets of Skokie will serve Jews poorly if it means that the freedoms to speak, publish, or assemble any place in the United States are thereby weakened....

It is dangerous to let the Nazis have their say. But it is more dangerous by far to destroy the laws that deny anyone the power to silence Jews if Jews should need to cry out to each other and to the world for succor.

409. Lawrence, at 466.

410. See M. Curtis, No State Shall Abridge: The Fourteenth Amendment and the BiLl OF RIGHTS 30-32 (1986).

411. Along with other provisions in the Bill of Rights, the first amendment did not purport to constrain state or local governments, but rather limited only the federal government. See Barron v. Baltimore, 32 U.S. (7 Pet.) 243 (1833). Not until 1931 did the Supreme Court hold that the fourteenth amendment (ratified in 1868) made the first amendment's free speech and press clauses binding on the states. See Near v. Minnesota, 283 U.S. 697, 707 (1931). See also Gitlow v. New York, 268 U.S. 652 (1925) (suggested in dicta that first amendment might be binding on states). Therefore, for general reasons of federalism, throughout much of U.S. history, the first amendment protected no speech against violations by state and local governments; it necessarily coexisted not only with slavery, but also with whatever other limitations states or local governments chose to impose on the speech and other rights of their citizens.

412. See Marbury v. Madison, 5 U.S. (1 Cranch) 137 (1803). 
context. ${ }^{413}$ Thus, under the Espionage Act of 1918 and similar state statutes, numerous individuals were punished for expressing unpopular political opmions. The first amendment did not prevent these laws from contributing to "the gravest period of political repression in American history." 414

In short, although slavery coexisted with the theoretical guarantees enunciated in the first amendment, slavery did not coexist with the judicially enforceable version of those guarantees that emerged only after World War I. We never can know how inuch inore quickly and peacefully the anti-slavery forces might have prevailed if free speech and press, as well as other rights, had been judicially protected against violations by all levels of government earlier in our history. That robust freedoms of speech and press ultimately might have threatened slavery is suggested by southern states' passage of laws limiting these freedoms, in an effort to undermine the abolitionist cause. ${ }^{415}$

The second basis for Professor Lawrence's lack of "faith in free speech as the most important vehicle for liberation"416 is the notion that "equality [is] a precondition to free speech."417 Professor Lawrence maintains that racisin devalues the ideas of non-whites and of anti-racism in the marketplace of ideas. ${ }^{418}$ Like the economic market, the ideological market sometimes works to improve society, ${ }^{419}$ but not always. ${ }^{420}$ Odious ideas, such as the idea of black inferiority, will not necessarily be driven from the marketplace. Therefore, the marketplace rationale alone might not justify free speech for racist thoughts. ${ }^{421}$ But that rationale does not stand alone.

413. See Lamont v. Postmaster General, 381 U.S. 301 (1965). See also L. TR1BE, supra note 58, $\S 1-2$, at $4 \mathrm{n} .8$ ("[S]uccessful invocation of the Bill of Rights to protect from Congress what would today be called 'civil rights' or 'civil liberties' dates from the 1950's.").

414. A. NEIER, supra note 63, at 110 (noting, for example, that Rose Pastor Stokes received a ten-year prison sentence for saying, "I am for the people and the government is for the profiteers," and that socialist leader Eugene V. Debs and Congressman Vietor Berger went to prison for similar remarks; similarly, a man in Minnesota received a prison sentence for saying to volunteer knitters, "No soldier ever sees these socks.").

415. See M. CuRTIS, supra note 410 , at 40 .

416. Lawrence, at 466.

417. Id. at 467.

418. See id. at 470 .

419. See A. NEIER, supra note 63 , at 170 (Although Nazis had received national press attention during 16 months of Skokie controversy, they gained no new adherents; "[t]hey had disseminated their message and it [was] rejected."); S. WALKER, supra note 16, at 59-62 (Ku Klux Klan's exercise of free speech rights led to decline in Klan's influence, which had been significant during 1920s).

420. This paragraph, the following paragraph, and the accompanying footnotes, are drawn in large part from Gale \& Strossen, supra note 19, at 174-76.

421. For criticisms of this metaphor, see Baker, Scope of the First Amendment Freedom of Speech, 25 UCLA L. REv. 964 (1978); Ingber, The Marketplace of Ideas: A Legitimizing Myth, 1984 DuKe L.J. 1. 
The civil libertarian and judicial defense of racist speech also is based on the knowledge that censors have stifled the voices of oppressed persons and groups far more often than those of their oppressors. ${ }^{422}$ Censorship traditionally has been the tool of people who seek to subordinate minorities, not those who seek to hiberate them. As Professor Kalven has shown, the civil rights movement of the 1960s depended upon free speech principles. ${ }^{423}$ These principles allowed protestors to carry their messages to audiences who found such messages highly offensive and threatening to their most deeply cherished views of themselves and their way of life. Equating civil rights activists with Communists, subversives, and criminals, government officials mounted mquisitions against the NAACP, seeking compulsory disclosure of its membership lists and endangering the members' jobs and lives. ${ }^{424}$ Only strong principles of free speech and association could-and did-protect the drive for desegregation. ${ }^{425}$ Martim Luther King, Jr. wrote his historic letter from a Birmingham jail, ${ }^{426}$ but the Birningham parade ordimance that King and other demonstrators had violated eventually was declared an unconstitutional invasion of their free speech rights. ${ }^{427}$ Moreover, tlie Civil Rights Act of 1964, which these demonstrators championed, did become law. ${ }^{428}$

The more disruptive forins of protest, which Professor Lawrence credits with having been more effective ${ }^{429}$ - such as marches, sit-ims, and

422. See, e.g., L. Levy, Emergence of a Free Press 6 (1985) (describing historical English system whereby "[t]he manuscript of any work intended for publication had to be subinitted to royal officials enpowered to censor objectionable passages .... Anything published without an imprimatur was criminal."); Dorsen, supra note 72, at 133 (discusses public attempts to censor the messages of Vietnam protestors, civil rights activists and labor unions); Strossen, supra note 230, at 220-22 (discusses the danger of government censorship of pornography being used to suppress any messages that are inconsistent with the personal value judgments of the government officials).

423. See H. Kalven supra note 133, at 4 (looks "at the impact of the [civil rights movement] on ... free speech . . . . trace[s] connections between civil rights and civil liberties"); see also id. at 6 ("[A]s a thumbnail summary of the last two or three decades of speech issues in the Supreme Court, we may coine to see the Negro as winning back for us the freedoms the Communists seemed to have lost for us.").

424. T. Branch, Parting the Waters: America IN the King Years 1954-63, at 181-82, 468-69 (1988). See also K. O'Reilly, "RAcial MatTers": The FBl's Secret File on Black AMERICA, 1960-72, at 125-55 (1989) (describing the FBl's attempt to link Martin Luther King, Jr. and other leaders of the civil rights movement with communism).

425. For Supreme Court decisions protecting the NAACP against forced disclosure of its membership lists, see Louisiana ex rel. Gremillion v. NAACP, 366 U.S. 293 (1961); Bates v. Little Rock, 361 U.S. 516 (1960); NAACP v. Alabama, 357 U.S. 449 (1958).

426. M. L. KING, Letter From Birmingham Jail, in WHY WE CAN'T WAIT 76 (1964). For a description of the circumstances in which the letter was written, see T. BRANCH, supra note 424, at 737-44.

427. Shuttlesworth v. Birmingham, 394 U.S. 147 (1969).

428. Pub. L. No. 88-352, 78 Stat. 241 (1964) (codified as amended in Title 28, § 1447; Title 42, $\S \S 1971,1975 \mathrm{a}-1975 d, 2000 \mathrm{a}$ to $2000 \mathrm{~h}-6$ (1988)).

429. See Lawrence, at 466 \& n.129. 
kneel-ins-were especially dependent on generous judicial constructions of the free speech guarantee. ${ }^{430}$ Notably, many of these protective interpretations initially had been formulated in cases brought on behalf of anti-civil rights demonstrators. Similarly, the insulting and often racist language that more militant black activists hurled at police officers and other government officials also was protected under the same principles and precedents. ${ }^{431}$

The foregoing history does not prove conclusively that free speech is an essential precondition for equality, as some respected political philosophers have argued. ${ }^{432}$ But it does belie Professor Lawrence's theory that

430. See S. WALKER, supra note 16, at 241. The author states that, "after 1960, the sit-ins and other forms of increasingly militant protest depended on new definitions of First Amendment rights. ... [T] [Te early civil rights movement depended on the First Amendment. As Georgetown University Law School professor Eleanor Holmes Norton later put it, 'There was always the First.' " (quoting from interview).

The record does not support Professor Lawrence's assertion that "the disruption that renders this speech effective usually causes it to be considered undeserving of first amendment protection." Lawrence, at 467. First, some of the authorities he cites in support of this generalization involved demonstrations that were accompanied by violence-including violence that "seemed to emanate from the protestors"-and not just disruption. Id. at 467 n.130. It would be ironic if Professor Lawrence, who aceuses traditional civil libertarians of being too absolutist in defending free speech, would be even more absolutist by suggesting that violent expressive conduct should be protected.

If one focuses on expressive conduct that "disrupt[ed] business as usual," id. at 466, but was not accompanied by protestor violence, one finds a consistent line of Supreme Court cases sheltering such conduct under the first amendment. See, e.g., NAACP v. Claiborne Hardware Co., 458 U.S. 886 (1982) (protected nonviolent elements of black citizens' boycott of white merchants to press for civil rights goals, although boycott caused substantial economic losses); Edwards v. South Carolina, 372 U.S. 229 (1963) (reversed breach of breach of peace convictions of 187 civil rights protesters who had demonstrated on state capitol grounds, although there was evidence that some sidewalks had been blocked during demonstration). See also Gregory v. Chicago, 394 U.S. 111 (1969) (in reversing disorderly conduct convictions for civil rights demonstrators who failed to disperse upon police order, Court refused to consider evidence that hostile crowd of 1,000 spectators was growing unmanageable); Cox v. Louisiana, 379 U.S. 536, 550 (1965) (reversed breach of peace convictions of civil rights demonstrators, despite local officials' claims that spectator violence was imminent, where there were 100 to 300 "muttering" spectators).

431. See Brown v. Oklahoma, 408 U.S. 914 (1972) (during political meeting in university chapel, appellant, a Black Panther, had referred to specific policemen as "mother-fucking fascist pig cops"; Supreme Court summarily vacated conviction under law which it found unconstitutionally overbroad); Gooding v. Wilson, 405 U.S. 518, 523 (1972) (where appellant, a black demonstrator, had made several threatening statements to police officers, including "White son of a bitch, I'll kill you," Court reversed conviction under law which it found unconstitutionally overbroad); see also Lewis $v$. New Orleans, 415 U.S. 130 (1974) (where police officer said to young suspect, "Get your black ass in the goddam car," and suspect's mother responded, "You god damn mother fucking police-1 am going to [the Superintendent of Police] about this," lower courts upheld mother's conviction on fighting words doctrine, but the Supreme Court reversed).

432. See, e.g., Beck, Liberty and Equality, 10 IDEALISTIC STUD. 24, 36 (1980) (liberty is "more basic" than equality); Machan, Equality's Dependence on Liberty, in 2 EQUALITY \& FREEDOM 663, 664-65 (G. Dorsey ed. 1977); Raphael, Tensions Between the Goals of Equality and Freedom, in id. at 543, 555 ("Freedom appears to be a greater value than equality."). For the contrary view (i.e., that equality is the source of all rights and liberties), see R. DWORkIN, TAKING Rights SERIOUSLY 
equality is an essential precondition for free speech. ${ }^{433}$ Moreover, this history demonstrates the symbiotic interrelationship between free speech and equality, which parallels the relationship between civil liberties and civil rights more generally. ${ }^{434}$ Both sets of aims must be pursued simultaneously because the pursuit of each aids the realization of the other. The mutual interdependence of equality and liberty was forcefully described by Professor Karst:

[T] he constitutional values of equality and liberty are fundamentally linked by the notion that equal access to certain institutions and services is a prime component of any meaningful liberty. This link is reflected in the language of egalitarian inovements. The civil rights inovement of the 1960 s, for example, marched under the banner of "Freedom" even though its chief objective was equal access-to the vote, to education, to housing, even to lunch counters. "Liberation" is today a theme of inore than rhetorical siguificance in egalitarian causes such as the woinen's movement. ${ }^{435}$

\section{CONCLUSION}

Some traditional civil libertarians may agree with Professor Lawrence that a university rule banning a narrowly defined class of assaultive, harassing racist expression might comport with first amendnient principles and make a synibolic contribution to the racial equality mandated by the fourteenth aniendment. However, Professor Lawrence and other menibers of the academic community who advocate such steps nuust recognize that educators have a special responsibility to avoid the danger posed by focusing on symbols that obscure the real underlying issues.

The recent exploitation of the American flag as a symbol of patriotism, to distort the true nature of that concept, serves as a sobering reninder of this risk. Joseph S. Murphy, Chancellor of The City University of New York, recently offered lessons for educators from the flag-related controversies. His cautionary words apply even nore powerfully to the campus hate speech controversy, since the general responsibility of acadenics to call for an honest and direct discourse about compelling societal problenıs is especially great within our own communities:

As educators, we should be somewhat concerned [about the manipulation of such symbols as the flag for partisan political purposes]. At our

$273-74$ (1977); Rawls, Justice as Faimess, 67 PHIL. Rev. 164, 165 -66 (1958). But see Hart, Between Utility and Rights, 79 CoLuM. L. REv. 828, 845-46 (1979) (criticizing Dworkin's view that all liberties derive from principle of equality).

433. See Lawrence, at 467.

434. See Gale \& Strossen, supra note 19 , at $184-86$.

435. Karst, supra note 141, at 43-44. 
best, we convey ideas in their full complexity, with ample appreciation of the ambiguity that attaches to most important concepts. We use symbols, but we do so to illuminate, not to obscure. ... The real question is how we use our position in the university and in society to steer national discourse away from an obsessive fixation on the trivial representation of ideas, and toward a proper focus on the underlying conflicts that define our era. ${ }^{436}$

An exaggerated concern with racist speech creates a risk of elevating symbols over substance in two problematic respects. First, it may divert our attention from the causes of racism to its symptoms. Second, a focus on the hateful message conveyed by particular speech may distort our view of fundamental neutral principles applicable to our system of free expression generally. We should not let the racist veneer in which expression is cloaked obscure our recognition of how important free expres. sion is and of how effectively it has advanced racial equality. 


\section{Appendix: ACLU Policy Statement}

\section{Free Speech and Bias on College Campuses ${ }^{437}$}

\section{Preamble}

The significant increase in reported incidents of racism and other forms of bias at colleges and universities is a nuatter of profound concern to the ACLU. Some have proposed that racisni, sexisn, honiophobia and other such biases on campus must be addressed in whole or in part by restrictions on speech. The alternative to such restrictions, it is said, is to permit such bias to go unremedied and to subject the targets of such bias to a loss of equal educational opportunity. The ACLU rejects both these alternatives and reaffirms its traditional and unequivocal commitment both to free speech and to equal opportunity.

\section{Pohicy}

1. Freedom of thought and expression are indispensable to the pursuit of knowledge and the dialogue and dispute that characterize meaningful education. All menibers of the acadenic community have the right to hold and to express views that others may find repugnant, offensive, or eniotionally distressing. The ACLU opposes all campus regulations which interfere with the freedom of professors, students and administrators to teach, learn, discuss and debate or to express ideas, opinions or feelings in classroon, public or private discourse. ${ }^{438}$

2. The ACLU has opposed and will continue to oppose and challenge disciplinary codes that reach beyond permissible boundaries into the realm of protected speech, even when those codes are directed at the problem of bias on canipus. ${ }^{439}$

3. This policy does not prohibit colleges and universities from enacting disciplinary codes aimed at restricting acts of harassnent, intimidation and invasion of privacy. ${ }^{440}$ The fact that words niay be used in connection with otherwise actionable conduct does not immunize such conduct

437. Adopted by ACLU National Board of Directors, without dissent, on October 13, 1990.

438. See generally ACLU Policy Nos. 60, 63, 65, 71.

439. The ACLU to date has opposed overbroad student speech codes adopted by the University of Connecticut, University of Michigan and University of Wisconsin and the University of California.

440. Although "harassment", "intimidation", and "invasion of privacy" are imprecise terms susceptible of impermissibly overbroad application, each term defines a type of conduct which is legally proscribed in many jurisdictions when directed at a specific individual or individuals and when intended to frighten, coerce, or unreasonably harry or intrude upon its target. Threatening telephone calls to a minority student's dormitory room, for example, would be proscribable conduct under the terms of this policy. Expressive behavior which has no other effect than to create an unpleasant learning environment, however, would not be the proper subject of regulation. See also Policy No. 316. 
from appropriate regulation. ${ }^{441}$ As always, however, great care must be taken to avoid applying such provisions overbroadly to protected expression. The ACLU will continue to review such college codes and their application in specific situations on a case-by-case basis under the principles set forth in this policy and in Policy $72 . .^{442}$

4. All students have the right to participate fully in the educational process on a nondiscriminatory basis. Colleges and universities have an affirmative obligation to coinbat racisin, sexism, homophobia, and other forms of bias, and a responsibility to provide equal opportunities through education. To address these responsibilities and obligations, the ACLU advocates the following actions by colleges and universities:

(a) to utilize every opportunity to communicate through its administrators, faculty, and students its commitment to the elimination of all forms of bigotry on campus;

(b) to develop comprehensive plans aimed at reducing prejudice, responding promptly to incidents of bigotry and discriminatory harassment, and protectimg students from any such further incidents;

(c) to pursue vigorously efforts to attract enough minorities, women and members of other historically disadvantaged groups as students, faculty members and administrators to alleviate isolation and to ensure real integration and diversity in academic life;

(d) to offer and consider whether to require all students to take courses in the history and meaning of prejudiuce, including racism, sexism, and other forms of invidious discrimination; ${ }^{443}$

(e) to establish new-student orientation programs and continuing counselimg programs that enable students of different races, sexes, religions, and sexual orientations to learn to live with each other outside the classroom;

(f) to review and, where appropriate, revise course offerings as well as extracurricular programs in order to recognize the contributions of those whose art, inusic, literature and learning have been insufficiently reflected in the curriculum of many American colleges and universities;

(g) to address the question of de facto segregation in dormitories and other university facilities; and

(h) to take such other steps as are consistent with the goal of ensuring that all students have an equal opportunity to do their best work and to participate fully in campus life.

441. For example, intimidating phone calls, threats of attaek, extortion and blackmail are unprotected forms of conduct which include an element of verbal or written expression.

442. In determining whether a university disciplinary code impermissibly restricts protected speech, there must be a searching analysis both of the language of the code and the manner in which it is applied. Many factors, which are heavily fact-oriented, must be considered, including time, place, pattern of conduct and, where relevant, the existence of an authority relationship between speaker and target.

443. All courses and programs must be taught consistent with the principles prescribed in ACLU Policy 60. 
This policy is issued in connection witl, and is intended as an interpretation and enhanceinent of, the binding resolution on racist speecl adopted at the 1989 Biennial Conference. That resolution provides:

The ACLU should undertake educational activities to counter incidents of racist, sexist, anti-semitic, and homophobic behavior (including speech) on school campuses and should encourage school administrators to speak out vigorously against such incidents. At the saine time the ACLU should undertake educational activities to counter efforts to limit or punish speech on university campuses. 